\title{
GEOLOGIA E EVOLUÇÃO GEOLÓGICA DA FOLHA DE SÃO JOSÉ DOS CAMPOS, SP.
}

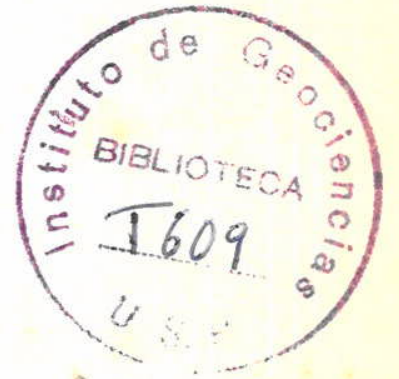

CELSO DAL. RÉ CARNEIRO

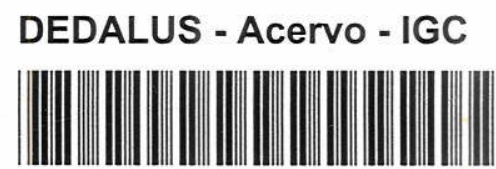

30900004706

DISSERTAÇÃO DE MESTRADO APRESENTADA AO INSTITUTO DE GEOCIÉNCIAS

DA UNIVERSIDADE DE SÃO PAULO 
A minha esposa Marli $e$ à minha filha Glauce 
I. INTRODUÇAOO

1. Objetivos

1

2. Area estudada

3. Metodologia

2

3

II. TRABALHOS ANTERIORES

5

7

IV. LITOLOGIAS

1. Generalidades

8

2. Rochas Cristalofilianas

A. BLOCOS MONTEIRO LOBATO E TERRA BOA

9

A.1. Ectinitos

A.1.1: Filitos

A.1.2. Xistos

9

10

A.2. Migmatitos

A.2.1. Migmatitos Heterogêneos Estromatiticos

A.2.2. Migmatitos Homogêneos Estromatíticos e Embrechiticos

15

A.2.3. Migmatitos Homogêneos Embrechiticos e Nebuliticos

A.3. Rochas Granitōides 24

A.4. Anfibolitos 25

B. BLOCOS SÃO JOSE DOS CAMPOS E SERRA DO JAMBEIRO 27

B. 1. Rochas migmatiticas

B.1.1. Migmatitos Heterogêneos Estromatiticos

B.1.2. Migmatitos Homogêneos Estromatíticos

de Composição Granitica 
B.1.3. Migmatitos Homogêneos Estromatiticos

e Embrechiticos de Composicão

Tonalitica

B.1.4. Migmatitos Homogêneos Embrechíticos

e Nebuliticos

B.2. Rochas granitöides

C. BLOCO BENGALA

C.1. Migmatitos

C.1.1. Migmatitos Homogêneos Estromatiticos e Embrechíticos

C.1.2. Migmatitos Embrechíticos

C.2. Granulitos

3. Rochas Cataclásticas

4. Rochas Intrusivas Básicas

5. Sedimentos Terciários

6 . Sedimentos Modernos

V. ESTRATIGRAFIA

VI. MAGMATISMO

VII. METAMORFISMO

VIII. ESTRUTURAS

1. Estruturas do Embasamento

2. Estruturas Relacionadas à Reativação da Plataforma

IX. GEOHORFOLOGIA 
1. Zona do Mëdio Vale do Paraíba

A. SUBZONA DOS MORROS CRISTALINOS

B. SUBZONA DA BACIA DE TAUBATE

2. Zona da Serra da Mantiqueira

A. SUBZONA OCIDENTAL

$X$. RECURSOS MINERAIS 
INDICE DAS ILUSTRAÇOES

FOTOS

26 Fotografias e 9 Fotomicrografias intercaladas e numeradas de 1 a 35

FIGURAS

1. Situação das āreas jā estudadas no pré-cambriano de São Paulo.

2. Compartimentação tectônica da quadrīcula.

3. Corpos magmäticos na quadrícula.

4. Domïnios homogêneos escolhidos para anālise estrutural.

5. Sistemas de juntas e bloco unitārio na ārea 1.

6. Sistemas de juntas e bloco unitārio na ärea 2.

7. Sistemas de juntas e bloco unitārio na área 3.

8. Sistemas de juntas e bloco unitārio na ārea 4.

9. Sistemas de juntas e bloco unitārio na ārea 5.

10. Sistemas de juntas e bloco unitārio na área 6.

11. Mapa da Bacia de Taubatē entre Jacareí e Caçapava.

12. Perfis geológicos na Bacia de Taubaté.

13. Zonas Geomorfológicas na quadrícula.

MAPAS

Mapa Geológico da Folha de São José dos Campos (anexo 1). Mapa de Lineamentos Fotogeológicos da Folha de São josé dos Campos (anexo 2). 
0 embasamento da porção sudeste da Plataforma Sul-americana é constituīdo pela Região de Dobramentos do Sudeste. Os traços mais gerais de sua evolução tectónica es tão delineados pelos trabalhos de sintese mais recentes (Ha sui et a1., 1975 e Almeida et a1., 1976). Para se compreender esta evolução em termos mais profundos, torna-se necessário o estudo geológico pormenorizado ao longo de toda a sua extensão.

$$
\text { A realização de tais estudos geológicos em }
$$
nosso Pré-Cambriano envolve inicialmente o mapeamento geoló gico de detalhe, que é apenas uma primeira etapa. As observações de campo, complementadas com as de laboratório, são tratadas com o objetivo de caracterizar as litologias e principalmente as estruturas, não só em termos geométricos, mas também de evolução no tempo. Desse modo, reconstitui-se a histōria geológica ao nível de fases de deformação e even tos de magmatismo e metamorfismo. A geocronologia, quando disponível, permite situar na escala do tempo geológico a histōria reconstituída. Os dados litológicos e de estrutu ras primārias podem permitir uma reconstituição da estratigrafia e da evolução sedimentar.

Dentro desta linha geral de investigação, tivemos o ensejo de estudar a geologia da folha de São José dos Campos, SF-23-Y-D-II-1, na região do Vale do Paraỉba.

os objetivos do estudo, portanto, podem ser 
resumidos em dois itens:

I - Mapeamento Geológico de detalhe.

II - Reconstituição da evolução geológica da àrea.

\section{Area Estudada}

A ārea de estudo é a folha de são José dos Campos, SF-23-Y-D-II-1, na escala de 1:50.000, recobrindo uma superfície aproximada de $710 \mathrm{~km}^{2}$. Com $15^{\prime}$ de lado, situa se entre os paralelos $23000^{\prime}$ e $23015^{\prime} \mathrm{S}$ e os meridianos 450 45' e 46900'. E quase inteiramente ocupada pelo município de São José dos Campos, seus bairros, vilas e ārea urbana. A c dade, importante polo no Vale do Paraíba, situa-se na porção sudeste da folha e é por onde passam a Rodovia Presidente Du tra e a via férrea que une São Paulo ao Rio de Janeiro, da RFFSA. E também o ponto de junção das estradas que levam a Campos do Jordão (SP-50), no alto da Serra da Mantiqueira, e a Caraguatatuba (SP-99), no Litoral Norte do Estado.

As estradas secundārias que cortam a quadrícu la formam um denso emaranhado próximo ao centro urbano e pas sam a ser mais espaçadas quando dele se afastam. A rede de drenagem associa-se toda ao Rio Paraiba do Sul e seus princi pais afluentes, que são os rios Jaguari e Buquira. 0 relevo reflete o substrato que o sustenta, e torna-se mais abrupto em direção à Serra da Mantiqueira. As altitudes médias estão em torno de 600-700 m sobre o nível do mar, com cristas de $\underline{s}$ tacando-se até a $1073 \mathrm{~m}$, na Serra do Palmital, maior expressão do relevo na quadrícula. As depressões atingem $543 \mathrm{~m}$, no Rio Paraíba do Sul, próximo a Caçapava, na borda Leste da fo 1ha.

A situação da área e a relação com outras anteriormente estudadas no Pré-Cambriano de São Paulo encontra se na figura 1. 
Fig. I - SITUAÇĀO DA FOLHA DE SĀO JOSÉ DOS CAMPOS E RELAÇĀO COM ÁREAS JÁ MAPEADAS NA REGIĀODE SĀO PAULO LEGENDA

\begin{tabular}{|c|c|}
\hline $\begin{array}{l}\because \because \therefore \\
\square \\
\end{array}$ & $\begin{array}{l}\text { Carneiro-1977 } \\
\text { Freitas-1976 }\end{array}$ \\
\hline $\mid \begin{array}{lll}0 & 0 & 0 \\
0 & 0 & 0 \\
\end{array}$ & Alves-1975 \\
\hline$=$ & Sadowski-1974 \\
\hline & Sadowski e Carneiro-1974 \\
\hline 1 & Algarte, et. al-1974 \\
\hline 2 & Cavalcante e Kaefer-1974 \\
\hline
\end{tabular}
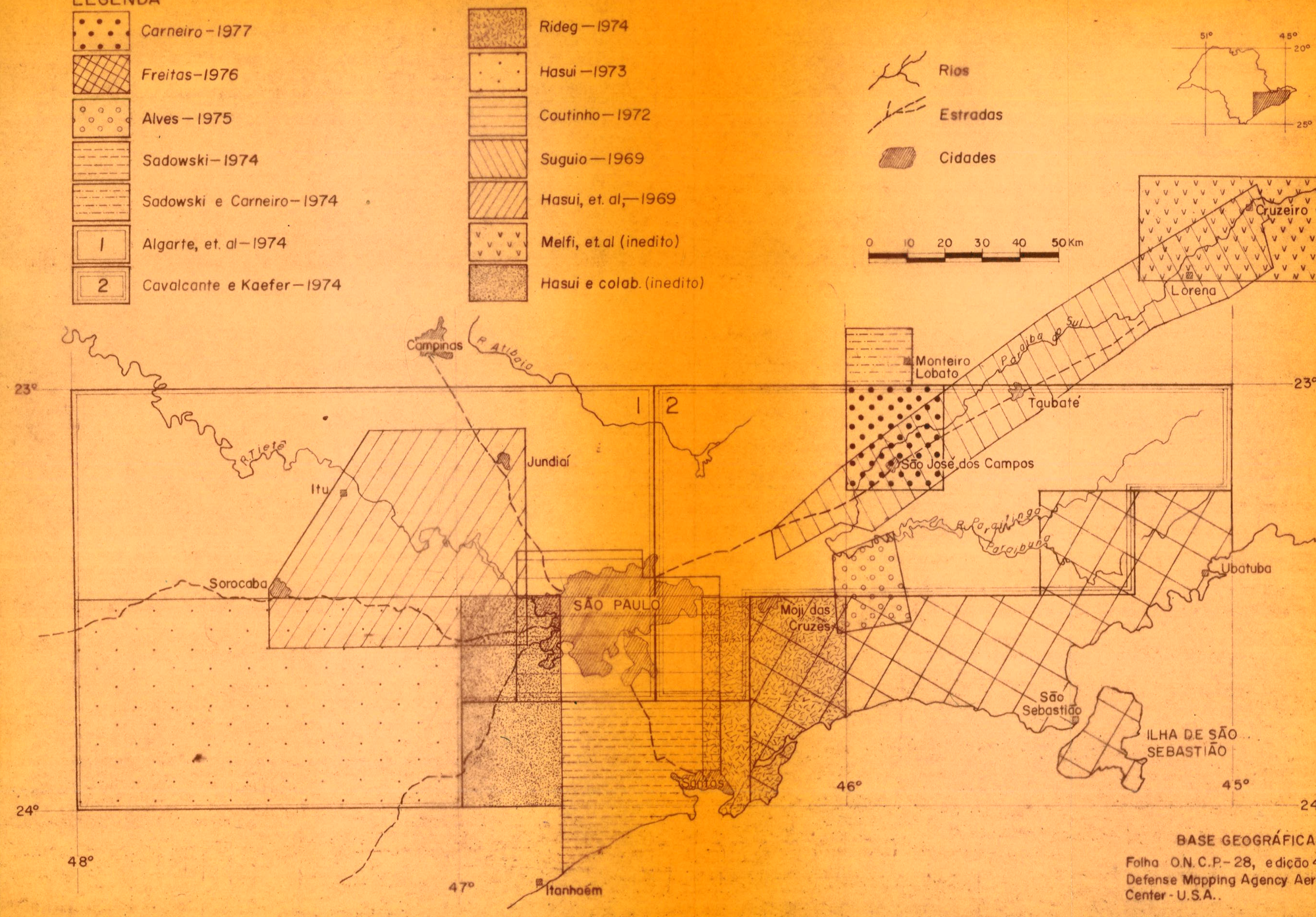
$23^{\circ}$

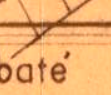


$\mathrm{Na}$ execução das atividades de campo, fizemos uso de mapas plani-altimétricos, escala 1:50.000, editados pelo IBGE e IGG. São as folhas de São José dos Campos, Camanducaia, Monteiro Lobato, Tremembé, Taubaté, Paraibuna e Jacareī (IBGE), e as de Santa Isabel e Igaratā (IGG). As fo tos aéreas usadas são da escala aproximada $1: 60.000$, tomadas em 1965/66 pelo vōo AST-10 da FAB/USAF, e da escala aproximada 1:25.000, obtidas em 1962 pela Aerofoto Nativida de Ltda.; Imagens de satélite ERTS-2 na escala 1:1.000.000 e foto-indices da Aerofoto Natividade em escala 1:100.000 foram consultados, para verificar a continuidade dos corpos litológicos maiores e possỉvel extrapolação das principais estruturas observadas.

As atividades de campo inicialmente envolveram o reconhecimento geológico de uma região mais ampla, quando levantamos perfis ao longo das principais vias de acesso; isto possibilitou uma foto-interpretação preliminar. Em seguida, realizamos o mapeamento geológico de detalhe,na escala de 1:50.000, de modo sistemático. Nesta segunda fase, percorremos todas as estradas trafegāveis e, nos locais de importância para o estudo, também caminhos foram percorridos a pé, para acesso a elevações e a fundos de vales. Fo ram percorridos um total de $980 \mathrm{~km}$ de perfis e coletadas 247 amostras, recolhidas dentre os 421 afloramentos cadastrados para controle.

Utilizamos a técnica de perfis continuos aos invēs de observações puntuais, o que traz a vantagem de per mitir jā no campo uma visão da situação geológica e uma a mostragem racional dos tipos litológicos. Há uma notável re dução do número de afloramentos cadastrados, pois a técnica não exige anotações em cada um dos pontos de parada. Os dados foram compilados nas folhas base; na folha de são josé dos Campos, para evitar sobrecarga de símbolos, foram usa 
das duas cópias, coladas em cartão duro, uma contendo os da dos de geologia e outra com a numeração das amostras e dos pontos cadastrados. As amostras foram coletadas em aflora mentos de rocha sã ou pouco alterada.

A fotointerpretação acompanhou as etapas do mapeamento geológico. Iniciada após o reconhecimento geológico, teve caráter de orientação para os trabalhos de campo a serem executados. Ainda nesta etapa, os lineamentos fotogeológicos foram lançados em um mapa-base, a partir das fotos aéreas, por meio de Aerosketchmaster Leitz (câmara clara). Ao final dos trabalhos de campo, o estudo das fotos aé reas possibilitou a elaboração de um mapa fotogeológico,con trolado pelos dados de campo e sujeito a modificações pelos resultados das anālises petrográficas.

0 estudo das amostras seguiu as técnicas e critērios convencionais para o exame de secções delgadas ao microscópio polarizador e para as observações macroscópicas. Foram usados microscópios marca Leitz-Wetzlar e uma lupa binocular marca Bausch \& Lomb. Nestes estudos, objetivou-se a caracterização da paragênese mineral de cada amostra e das microestruturas contidas.

A anālise estrutural seguiu os princípios di tados por Turner e Weiss (1963), Whitten (1966), Ramsay (1967), Hobbs et al (1976)e Vialon et al (1976). Nos dominios homogéneos escolhidos, foram feitas medidas de estrutu ras planares e lineares, em número adequado para represen tar os sistemas presentes. Os dados foram lançados em diagrama de Schmidt -Lambert, por projeção estereográfica dos polos de planos e retas. A distribuição de polos, analisada pelos meios estatísticos adequados à técnica, conduziu à de terminação das orientações preferenciais das estruturas e de suas relações geométricas.

A nomenclatura utilizada, quando passível de controvērsias, serā devidamente definida nos locais oportunos do texto. 
A compilação feita por Florence e Pacheco pa ra elaborar o Mapa Geológico do Estado (1929) não diferenciou as rochas cristalofilianas da Região do Vale do Paraíba, e as incluiu no Complexo Arqueano. Dois andares dentro deste Complexo foram distintos por Moraes Rego (1933 a) e a idade arqueana foi mantida por Ribeiro Filho (1948).

Deve-se a Knecht (1964) a sintese de conhecimentos sobre o Pré-Cambriano Inferior que acompanhou o Ma pa Geológico do Estado. Coube a Paoliello (1964), na mesma obra, a descrição das unidades do Pré-Cambriano Superior.

Estudos regionais na região Sul de Minas Gerais e Estado do Rio de Janeiro possibilitaram a Ebert (1957) e Rosier (1965) a distinção de sequēncias de rochas metamōrficas que foram incluídas nos Grupos Paraíba, Andre lândia e São João Del Rey. A Formação Barbacena foi definida por Ebert (1967, 1968). Datações radiométricas destas sequências foram apresentadas por Delhal et al (1969)e Corda ni et al (1973).

Na região de São Paulo, a oeste da Capital, os mapeamentos geológicos mais recentes são devidos a Hasui et al (1969), Coutinho (1972), Hasui (1973), Sadowski (1974), Rideg (1974) e foram objeto de uma sintese regional por Hasui e Sadowski (1976).

A região do Vale do Paraíba paulista, situada entre as grandes āreas acima referidas, só vem sendo car tografada geologicamente em tempos mais recentes e os mapas já divulgados devem-se a Cordani et al (1974), Cavalcante e 
No tocante à Bacia Sedimentar de Taubaté, vā rios pesquisadores detiveram-se no exame dos depósitos, gênese, idade e significado geomorfológico. (Carneiro, 1974).

Os sedimentos que preenchem a fossa foram descobertos por Pissis (1842) e mapeados por Derby (1895), Florence e Pacheco (1907, 1929) e Branner (1918). A origem da bacia foi atribuída a movimentos tectónicos por vários pesquisadores, como Lamego (1949), Freitas (1951, 1956 e 1957), Almeida (1955, 1957), Ab'Saber e Bernardes (1956), Ab'Saber (1957a, 1957b), Tricart e Silva (1958), Frangipani (1963), Frangipani e Pannutti (1965)e Suguio (1969), embora a existēncia de falhas tenha jā sido sugerida por Washburne (1930) e Maull (1930). Na falta de evidencias mais seguras, Moraes Rego (1933b) preferiu interpretar a depressão como re sultado de fenômenos erosivos.

A natureza dos depósitos foi investigada por Suguio (1969) e as feições geomorfológicas regionais foram abordadas por Almeida (1964), Ab'Saber (1969a, 1969b), Titą rel1i (1975) e Coltrinari (1975).

A idade dos sedimentos é controvertida; os dados geológicos e geomorfológicos conduziram a uma idade Pliocénica pelo menos para os estratos inferiores da sequên cia e as evidéncias paleontolögicas indicaram idade referível ao Pleistoceno (Santos, 1950, 1970; Santos e Travassos, 1955; Beurlen, 1950; Paula Couto, 1956, 1958; Caster e Mendes, 1952; Mendes e Petri, 1971). A descoberta de fósseis característicos do 01 igoceno a Mioceno inferior levou Paula Couto e Mezzalira (1971) a rever a idade Pleistócēnica atrị buîda āquelas camadas. 
Os grandes falhamentos transcorrentes que com põem a Zona de Transcorrência São Paulo (Hasui et al 1975), estão representados na região estudada pelos falhamentos de Monteiro Lobato, descrito por Sadowski e Carneiro (1974); do Rio Jaguari, descrito por Cavalcante e Kaefer (1974) e os de Buquira e Bom Retiro, descritos por Carneiro et al (1976).

As descontinuidades mais recentes são as faThas normais do Palmital, Parateí, São José e Rio Comprido, descritas por Carneiro et al (1976) e que estão relacionadas à própria evolução da Bacia de Taubaté.

As zonas de falhamento transcorrente separam blocos de forma alongada que, a par da extensão das falhas limitrofes, estendem-se para fora da quadrícula estudada. São eles os blocos de Terra Boa, Monteiro Lobato, Bengala, São José dos Campose Serra do Jambeiro. A distribuição destes blocos e as falhas que os separam estão indicadas na Fig.2.

Os sedimentos da Bacia de Taubaté na folha São José dos Campos, restringem-se ao Bloco São Josē dos Cam pos e a parte do Bloco Serra do Jambeiro (vide Mapa Geológico). Os seus limites são as falhas do Parateí e Palmital na borda Norte e as falhas do Rio Comprido e Bom Retiro, na par te sul. No interior da Bacia, a falha de São José divide os sedimentos em dois compartimentos: o Compartimento Parateí e - Compartimento Jacareí (Carneiro et al 1976). 


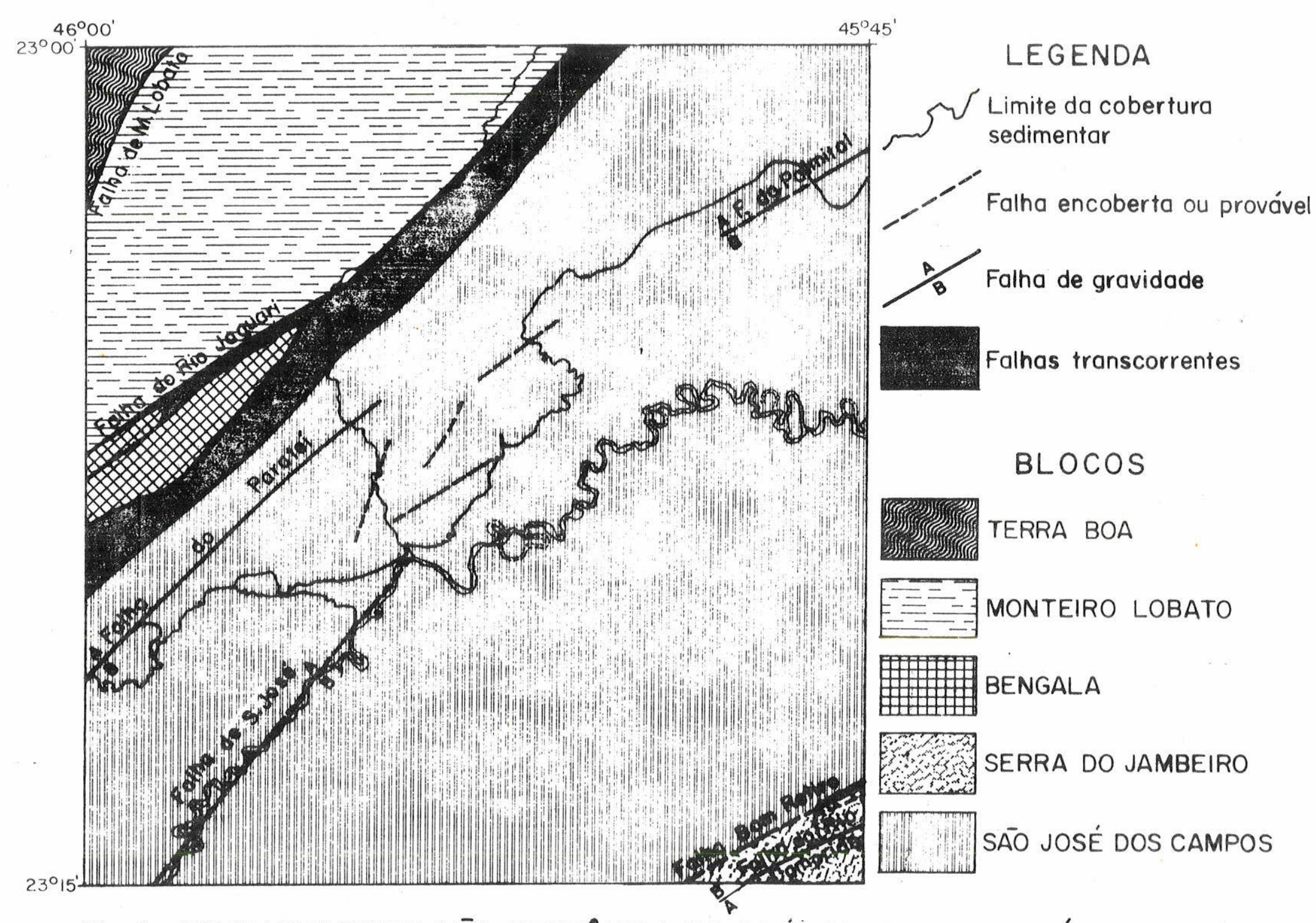

FIg.2-COMPARTIMENTACĀO TECTÔNICA DO PRÉ-CAMBRIANO NA ÁREA DA QUADRICULA DE SAOO JOSÉ DOS CAMPOS 


\section{LITOLOGIAS}

\section{Generalidades}

Na folha geológica de São José dos Campos, cinco unidades litolögicas principais se destacam:as rochas cristalofilianas, as rochas cataclásticas, as intrusivas bá sicas, os sedimentos terciārios e os sedimentos modernos.

No conjunto das rochas cristalofilianas são profundas as diferenças na constituição litológica dos vā rios blocos tectōnicos. Deste modo, este conjunto de rochas será tratado sob o ponto de vista dos cinco blocos em que se divide a ārea. Nas demais unidades, a abordagem será fẹ ta no àmbito da folha São José dos Campos.

$\mathrm{Na}$ descrição que se segue, frequentemente se rá feita referéncia a locais especīficos da folha de São José dos Campos, com o intuito de reforçar e tornar mais clara a exposição. Nestes casos, procuramos adotar os nomes de lugares ou acidentes geográficos que se encontram na car ta topográfica escala 1:50.000 correspondente, editada pe10 IBGE. 0 sistema de coordenadas utilizado nesta carta e nas adjacentes foi empregado, de modo que fornecemos entre parēnteses, após a designação da localidade, os seis algarismos que definem o ponto com precisão de 100 metros na fo Tha, acompanhados da sigla da folha topográfica em que se encontram. Para facilitar a leitura, sugerimos ao leitor a consulta às cartas topográficas referidas, quando nomes de locais citados no texto não aparecerem no mapa geológico. 
As Rochas do Bloco Terra Boa na região estudada são essencialmente micaxistos. Em razão da similaridade com os xistos do Bloco Monteiro Lobato, são aqui focalizados em conjunto.

\section{A.1. Ectinitos}

\section{A.1.1. Filitos}

Os filitos têm ocorrência restrita ao canto NW da quadrícula, nas encostas da margem esquerda do Rio do Peixe, no bloco Monteiro Lobato (vide mapa Geológico).

São rochas de textura fina e nos afloramen tos são sempre encontradas em estado parcialmente decomposto. A composição mineralógica é essencialmente sericita e quartzo. Os termos com baixo ou nulo conteúdo em quartzo tornam-se então untuosos ao tato e de brilho sedoso. A aspe reza é notada nos quartzo-filitos, de coloração bege-aver melhada quando parcialmente alterados. A coloração dos fil $\underline{i}$ tos é cinzenta em geral, com alternāncias frequentes de camadas ou lâminas negras que se repetem a intervalos milimétricos ou centimétricos. São similares aos metarritmitos de Hasui et al (1969) descritos no Grupo São Roque.

A xistosidade é bem desenvolvida, dada pela orientação dos cristais de sericita e também pelo quartzo de forma achatada. A coloração negra é dada por grafita ou matéria carbonosa, enquanto que as cores avermelhadas são devidas a óxidos de Ferro. A dificuldade de se obter amos- 
$-10-$ tras convenientemente sãs dificultou o exame deste tipo de rocha ao microscópio.

Os conspícuos planos de xistosidade são cortados por sistemas de juntas, o que confere à rocha parcial mente alterada a propriedade de se quebrar em fragmentos de formas variadas com cantos angulosos.

0 acamamento reliquiar é observāvel nestas rochas, particularmente na região do Bairro do Juarez ( $983527 / \mathrm{SJ})$ onde leitos quartzosos milimétricos a submilimé tricos de grão muito fino criam um bandeamento notável. A xistosidade é discordante do acamamento e o corta originando uma lineação pronunciada, paralela aos eixos das dobras mesoscópicas, talvez dobras intrafoliais geradas por transposição. Nos demais afloramentos a rocha não tem um caráter quartzoso tão pronunciado, e a estratificação não é tão clạ ra (Foto 1).

A presença de clivagem de crenulação defor mando a xistosidade é observada em alguns afloramentos. Nos cortes dos ūltimos quinhentos metros da estrada Bairro da Agua Soca - Rio do Peixe (025571/ML), observa-se planos de clivagem de crenulação verticais orientados segundo NE e que criam dobras de cizalhamento nos filitos.

\section{A.1.2. Xistos}

Rochas de aspecto xistoso são comuns na re gião estudada, de tal forma que houve necessidade de se estabelecer um limite para o conteúdo em neossoma nas rochas xistosas, com o objetivo de separar litologias puramente ec tiniticas das migmatizadas. Este limite foi de $20 \%$.

Os xistos têm seu domĩnio nos blocos Montei.- 
$-11-$

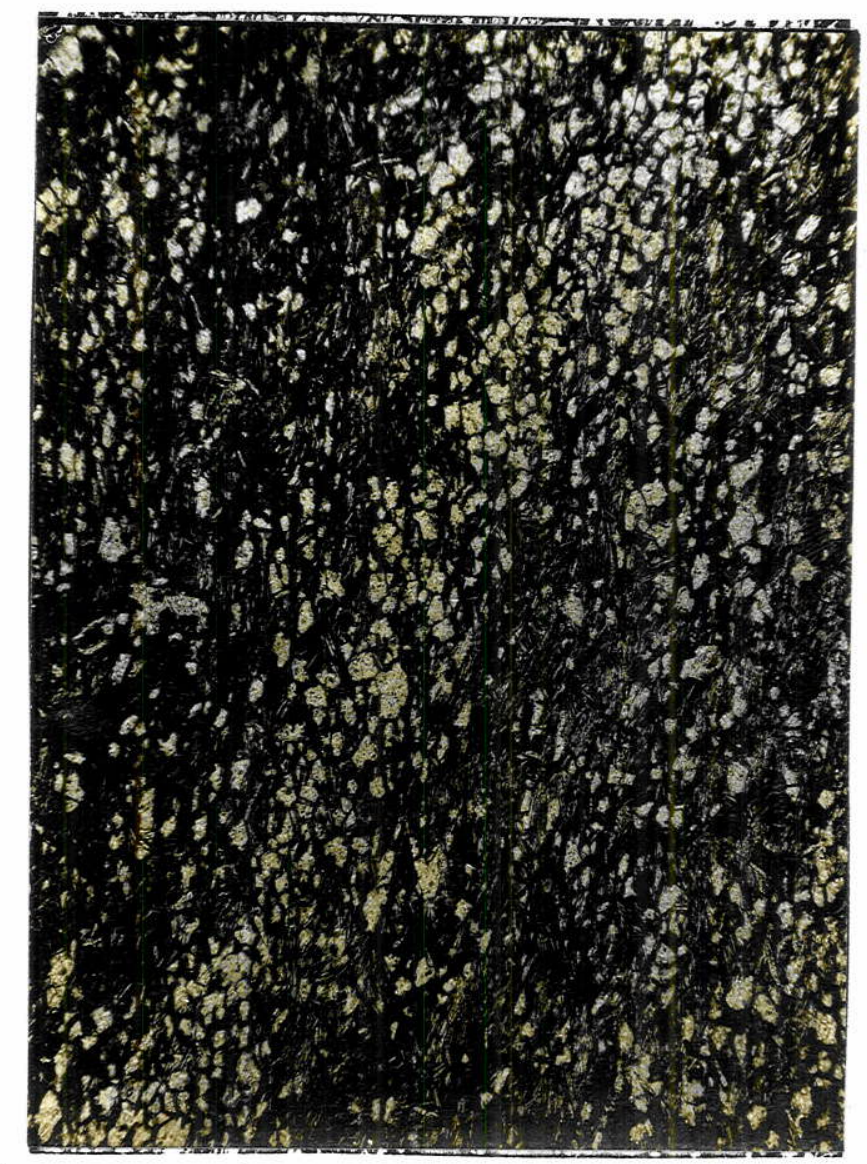

FOTO 1 - Fotomicrografia de Quartzo-filito que exibe xistosidade plano-axial (na posição vertical) cortando de modo incipiente a estratificação reliquiar (na posição inclinada). Esta é dada pela alternância de faixas mais ricas com outras menos ricas em quartzo, enquanto aquela é devida a uma orientação regular dos placóides e é ressaltada pela presença de óxidos de Ferro. Bairro do Juarez, proximidades do Rio do Peixe. Nícois paralelos, $20 x$. 
ro Lobato e Terra Boa. São muito restritos no bloco São José dos Campos e não foram observados nos blocos Bengala e Serra do Jambeiro (vide mapa Geológico).

No bloco Monteiro Lobato, das três faixas de xistos identificadas, numa delas foram reconhecidas caracte risticas de estrutura sinformal, sendo por conseguinte deno minada "Sinclinōrio do Morro Podre". As demais faixas apresentam bordas tectōnicas e não foi possível deduzir seu com portamento espacial.

Em todos os afloramentos visitados o estado de decomposição é avançado, de sorte que não se pode examinar a rocha sã ou inalterada. A coloração avermelhada é constante nas exposições, e em um ou outro ponto vêm-se películas negras superficiais, relacionadas hipoteticamente à presença de Mn no material semi-decomposto. No material de solo a coloração vermelha é generalizada.

Os minerais essenciais nos xistos dos blocos Monteiro Lobato e Terra Boa são moscovita e quartzo, embora a biotita esteja presente nos xistos do Sinclinōrio do Morro Podre. Minerais opacos e impregnações vermelhas talvez devidas a óxidos de $\mathrm{Fe}$, são encontradas nas läminas. 0 feldspato ocorre disperso em alguns afloramentos, formando ocelos até milimétricos. O quartzo concentra-se em leitos que se alternam aos de mica, caracterizando a estratificação reliquiar da rocha. Os leitos são lenticulares e descon tīnuos, centimétricos em extensão e milimétricos ou submili métricos em espessura. No interior das faixas quartzosas são comuns cristais de moscovita orientados ou subparalelos à xistosidade que por sua vez é paralela à orientação dos leitos quartzosos. A textura é geralmente fina a média, com cristais de 0,3 a $2 \mathrm{~mm}$.

A xistosidade é conspícua nestas rochas, embora nem todos os minerais micáceos estejam orientados. Por 
firoblastos de moscovita foram encontrados, com disposição. caótica na rocha. Seu significado será discutido adiante.

Planos de clivagem de crenulação frequentemente deformam a xistosidade e em alguns locais chegam até a desenvolver uma nova foliação no āpice de dobras desenha das pela xistosidade anterior.

Intercalações menos expressivas nesta unida de são os quartzitos e anfibolitos. Os primeiros exibem passagens graduais para os xistos, e ocorrem em leitos de dimensões métricas a centimétricas. Os anfibolitos possuem contatos bruscos onde foi possivel a observação. Na escala de mapeamento não puderam ser delimitados. No mapa geológi co de São José dos Campos estão assinaladas as ocorrências de tais intercalações.

\section{A.2. Migmatitos}

o termo migmatito, após introduzido por Sederholm (1907), tem sofrido modificações em seu significado original. Seriam rochas resultantes da mistura de um me tamorfito e um magma, gerando as associações intimas e com plexas de gnaisses e granitos. Posteriormente, a continuidade de fácies levou Sederholm a incluir misturas difusas como os nebulitos e arteritos nos migmatitos.

Em 1935, Wegmann estendeu o conceito de mig matito, englobando nesta categoria todos os gnaisses, mesmo os homogēneos, que adquiriram por injeção magmātica ou por metassomatose uma composição essencialmente feldspática. 0 limite entre os ectinitos e seu substrato migmatizado foi denominado por Wegmann de "front de migmatização".

A ampliação e modificação do conceito de Wegmann foi continua, trazendo por um lado teorias para ex 
plicar a gênese destas rochas e, por outro, classificações e novos termos, geralmente com conotação genética. A classificação proposta por Jung e Roques (1952) é dentre estas, aquela que retomou a conceituação de Wegmann, dividindo os migmatitos em heterogêneos (diadizitos, epibolitos e agmatitos) e homogēneos (embrechitos e anatexitos). Foi atribuída a essas rochas uma origem metassomática que se daria por intercâmbio iônico entre o paleossoma e fluidos (ichor) de proveniência não necessariamente magmātica que o percolariam através de zonas de resistência mīnima.

A existência de outros mecanismos de formação, tais como o de injeção magmática, o de fusão diferencial ou o de segregação, tornaram debatida a origem propos ta por Jung e Roques. Por outro lado, a facilidade de apli cação no campo é a razão pela qual a sua classificação teve boa aceitação nos meios que se dedicam ao mapeamento de āreas migmatīticas.

O abandono dos tipos homogêneos e o retorno ao significado original do termo migmatito foram propostas de Turner e Verhoogen (1960) e de muitos outros autores, nu ma polémica que se acentuou progressivamente, até que em 1960, no XXI Congresso Internacional de Geologia, em Cope nhage, Dietrich e Mehnert iniciaram uma 1 istagem das desig nações usadas para migmatitos. A lista final, onde foram sublinhados os termos escolhidos preferencialmente, sofreu uma suplementação por Roques e Polkanov (1968).

Mehnert, em 1968, face à necessidade de uni formizar a terminologia em bases essencialmente descritivas, propōs uma classificação de migmatitos da qual procurou eliminar as implicações genéticas. E a esta terminologia e a alguns dos termos de Jung e Roques que iremos nos ater neste estudo. 


\section{A.2.1. Migmatitos Heterogêneos Estromatíticos}

Conforme o Mapa Geológico, são três as fai xas de migmatitos heterogêneos de caráter estromatítico no bloco Monteiro Lobato. São corpos que, acompanhando a direção geral das estruturas, sustentam faixas das encostas da Serra do Roncador e dos serrotes que, do Morro do Jacu, dominam o Bairro da Ägua Soca. Dois destes corpos têm caracte rísticas sinformais, e constituem o sinclinōrio do Rio Turvo e parte do sinclinōrio do Morro Podre. Este ūitimo, como vimos no item precedente, contēm xistos no nūcleo.

As melhores exposições destas rochas encon tram-se na estrada que pelo Bairro da Água Soca liga a região do Rio do Peixe à SP-50 e na estrada que acompanha o Rio Turvo em toda a sua extensão. Qutros bons cortes po dem ser ainda encontrados em quase todas as estradas e caminhos que cruzam estas litologias.

Os migmatitos heterogēneos estromatîticos são rochas de estrutura caracteristicamente bandada, consti tuỉdas de um paleossoma xistoso, com foliação pronunciada e de coloração cinza a negra nas sequências biotiticas ou cin zenta a esbranquiçada nas sequências moscovīticas ou clorīticas. Neste paleossoma se intercalam bandas de neossoma quartzo-feldspático de coloração branca e o conjunto muitas vezes exibe outro tipo de estrutura de migmatitos, a dobrada. As bandas não são uniformes, pois irregularmente aumentam ou diminuem de espessura, desde dimensões milimétricas atē decimétricas.

A ação do intemperismo torna vermelhas as faixas de paleossoma, mantendo a cor branca do neossoma cau linizado. Esta é a situação mais frequente nos afloramentos.

A foliação do paleossoma é caracterizada pe- 
la orientação planar de micas, por planos de crenulação que podem estar presentes ou até mesmo por intercalações milimé tricas de natureza mais quartzosa entre as sequēncias micáceas. Corpos quartzíticos maiores podem ocorrer e têm forma alongada e descontīnua devida à estricção ou boudinage de camadas.

A assembléia mineralógica essencial do paleossoma é dada por biotita, moscovita e quartzo, em propor ções variāveis. As micas de uma primeira geração compõem a foliação, enquanto que as geradas posteriormente cortam-na. As micas posteriores são a moscovita e a clorita, com predo minio daquela. Nas frações quartzosas, a textura lepidoblás tica é dada por um arranjo imbricado dos cristais de quartzo com as palhetas de biotita ou moscovita.

Cristais de feldspato potássico (microclina) podem ocorrer sob a forma de ocelos dispersos no paleossoma caracterizando uma textura porfiroblástica. Os minerais a cessōrios ainda encontrados são plagioclásio (andesina sộd ca), apatita e opaco. A zoizita é secundāria.

O neossoma é constituīdo de quartzo e microclina, em proporções variáveis, dando uma textura aplítica. A presença de moscovita em palhetas dispersas, embora orien tadas, confere ao neossoma uma textura gnáissica.

Intercalações de quartzito feldspatizado levemente moscovitico e biotitico, assim como de quartzito calcossilicático foram verificadas. Os quartzitos calcossilicáticos apresentam-se constituỉdos de plagioclásio (bytow nita), quartzo, tremolita-actinolita e exibem como acessórios, biotita, titanita, zircão, clinozoisita, apatita e calcita. Estas rochas ocorrem no Bairro do Morro Podre e às margens do Rio Buquira, no trecho em que ele atravessa 0 bloco Monteiro Lobato (114550/SJ). Nesta ūitima região, o migmatito estromatítico tem localmente carāter homogēneo, 
mostrando texturas porfiroblāstica e gnāissica em faixas a ternadas, claras e escuras. Os porfiroblastos são de plagio clásio e, mais raramente, de microclina. Os minerais presen tes na matriz são o quartzo, plagioclásio, granada, moscovi ta, e como secundārios, a clinozoisita, clorita e sericita.

Outras ocorrēncias não mapeáveis de migmatito homogêneo encontram-se nas cabeceiras do Rio Claro $(014470 / S J)$ e no cōrrego Agua Soca, prōximo da SP- 50 $(073501 / \mathrm{SJ})$.

\section{A.2.2. Migmatitos Homogêneos Estromatíticos e} Embrechíticos

Representam a transição dos migmatitos heterogéneos para os migmatitos mais evoluídos que serão tratados no item seguinte. Estes ūltimos ocupam o núcleo de duas formas culminantes as quais têm os migmatitos homogêneos es tromatiticos como faixas marginais.

Afloramentos destas rochas são encontrados nas estradas que atravessam a porção sudoeste destes corpos, e mais particularmente, na pedreira próxima ao Bairro do Morro Podre (979448/55).

A rocha é de estrutura estromatitica, cinzenta a bege claro e tem um aspecto gnáissico dado pela dis tribuição homogênea dos máficos (Foto 2). Há um marcante cá ráter porfiroblástico devido aos ocelos elipsoidais de microclina que ondulam a foliação da rocha, como que contorna dos pelos cristais de mica das bordas dos porfiroblastos (Foto 3 ). As dimensões dos porfiroblastos atingem 8 milímetros, mas em média possuem 3-4 mm de comprimento. A matriz tem grão fino a médio. 


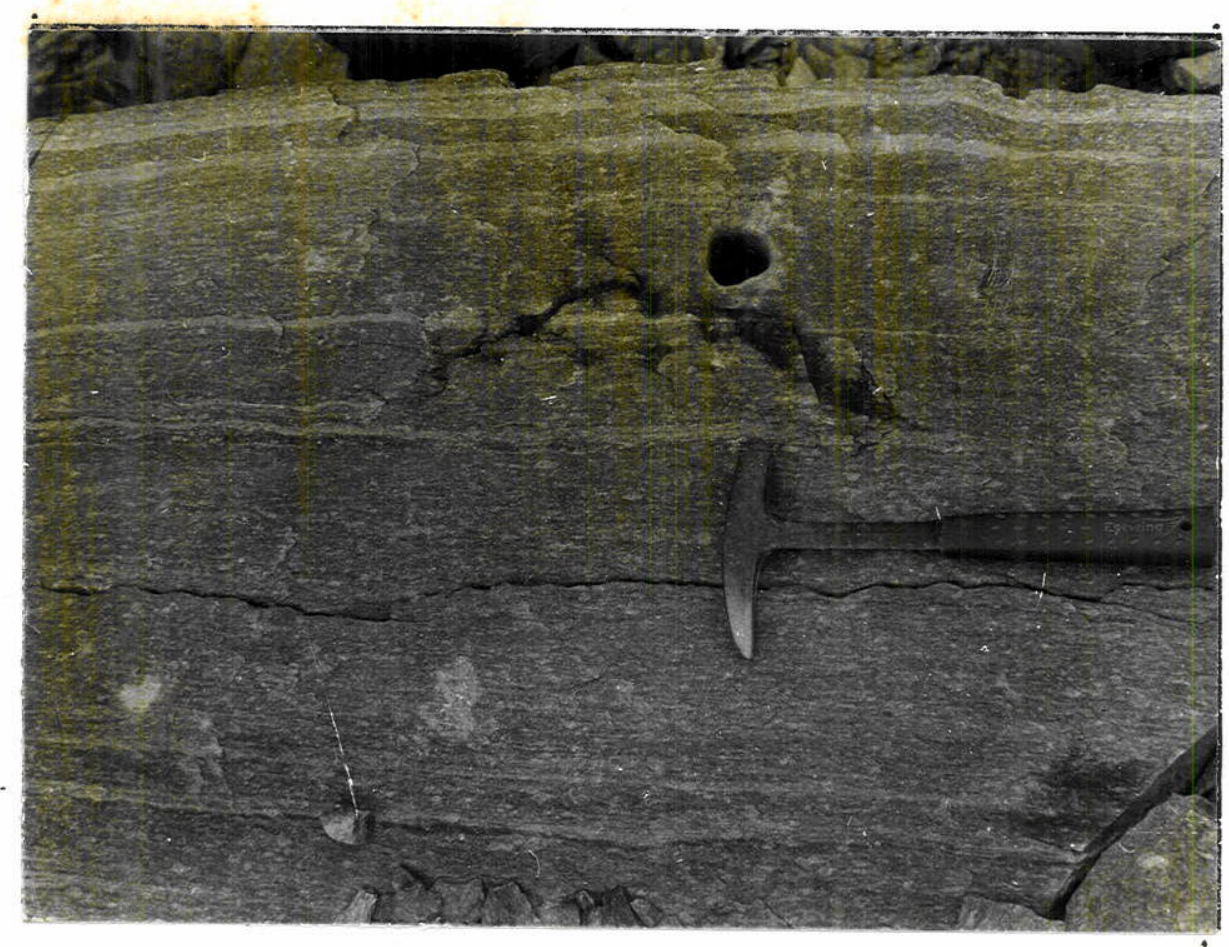

FOTO 2 - Estrutura estromatítica nos migmatitos homogêneos do Bloco Monteiro Lobato. Bairro do Bonsucesso, margem direita do Rio Turvo ( $979448 / \mathrm{SJ})$

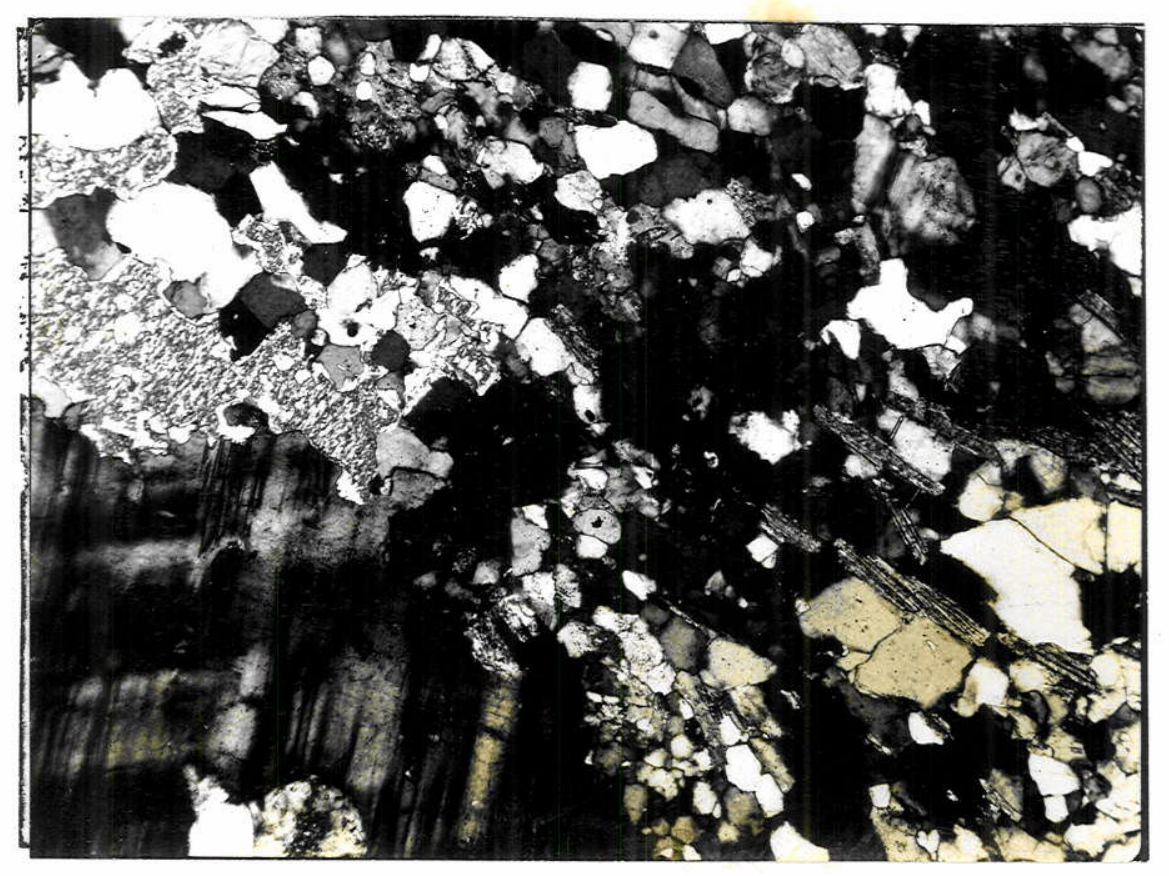

FOTO 3 - Fotomicrografia de migmatito homogêneo embrechít co mostrando a textura gnáissica e um porfiroblas to poiquiloblästico de moscovita desorientado (á esquerda). No canto inferior esquerdo há um porfi roblasto de microclina, contornado pelos minerais da matriz. Cabeceiras do Rio Claro (014470/SJ). 
A microclina e quartzo são os minerais essenciais, aos quais se subordinam o plagioclásio (oligoclá sio), a moscovita e a biotita, em proporções variāveis.os acessórios são o epídoto, apatita e opaco. A clorita apare ce mais localmente, substituindo a biotita e alguma moscovita.

0 quartzo forma cordões alongados paralelos à foliação e agregados granoblásticos na matriz, junto com a microclina e o plagioclásio. Os porfiroblastos de microclina possuem frequentes bordas mirmequiticas. Textura poi quiloblástica pouco desenvolvida é observada nos cristais de moscovita que atravessam a foliação, representando um segundo estāgio de cristalização de moscovita.

\section{A.2.3. Migmatitos Homogêneos Embrechiticos e Nebuliticos}

No nūcleo das estruturas antiformais cita das anteriormente, encontramos rochas homogēneas de aspecto granitóide que foram classificadas, de acordo com caracteres de campo e dados petrográficos, em rochas migmatí ticas embrechïticas e nebulīticas e rochas granitóides(vi de Mapa Geológico).

Estes corpos rochosos maiores são aqui deno minados Maciço do Roncador e Maciço a Rgua Soca, para efeito de sistematização. Ocorrem ao norte e ao sul do Rio Turvo, respectivamente.

Os migmatitos destas áreas são rochas de aspecto gnáissico, com foliação conspīcua e exibindo varia ções laterais notāveis. Não se pode caracterizar um bandea mento, pois não há repetição de uma faixa alternadamente 


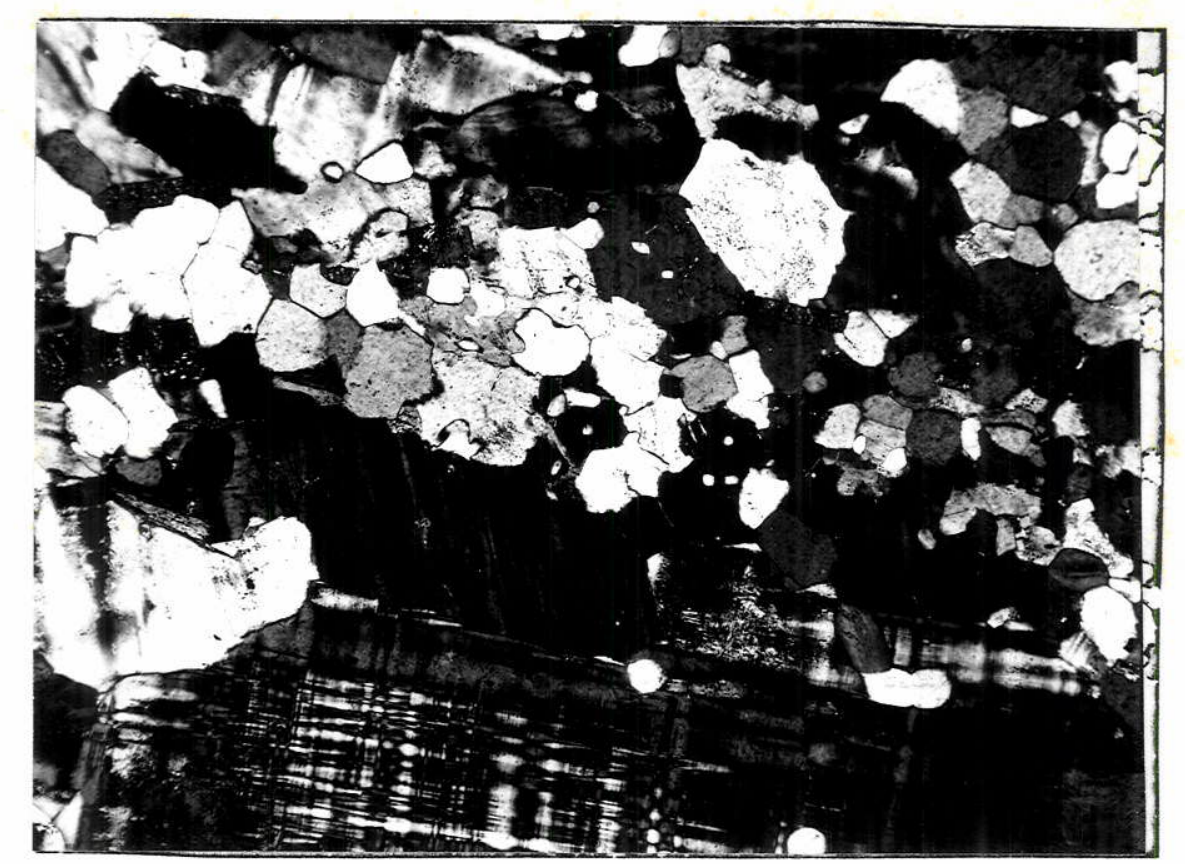

FOTO 4 - Fotomicrografia de nebulito exibindo as texturas gnáissica e granoblástica da matriz da qual se destaca o porfiroblasto de microclina com geminação Carlsbad (parte inferior da foto). Bairro da Água Soca, a $6 \mathrm{~km}$ da SP-50, Nicois Cruzados, $20 x$. 
com outras. O que ocorre são zonas de materiais que diferem nas proporções relativas dos componentes minerais, no tamanho dos cristais e na coloração da rocha, correspondendo às estruturas nebulitica, schlieren e oftalmitica de Mehnert (1968).

No maciço da Āgua Soca, os migmatitos são cinzentos a rosados, tendo como minerais essenciais quartzo, microclina e plagioclásio (oligoclásio); os acessórios são biotita, moscovita, titanita, apatita, allanita e opaco, em proporções variāveis. Clorita é mineral secundārio. A textu ra geral das rochas é a gnāissica. A textura porfiroblástica è mais frequente que a granoblāstica jā que esta se restringe às faixas menos micáceas (Foto 4). Os porfiroblastos são de microclina rósea ou branca, atingindo 2 a 3 centímetros nas variedades embrechiticas mais grosseiras e 3 a 4 milīmetros nas de granulação média. Em alguns pontos, a microclina apresenta textura poiquiloblástica, envolvendo cristais de biotita, quartzo ou da própria microclina.

Os migmatitos de estrutura nebulitica são de granulação fina a média, näo possuem porfiroblastos e exibem āreas irregulares onde varia a concentração de máficos, dando o aspecto de relictos "fantasmas" no seio da rocha ho mogênea. Isto se observa nos cortes da estrada que leva do Bairro da Ägua Soca ao Rio Turvo (056521/SJ), Foto 5. Nesta estrada também foram encontradas concentrações tipo "Schlie ren" $(063510 / \mathrm{SJ})$, fotos 6 e 7 .

No maciço do Roncador, o predomỉnio é de rochas granitōides menos orientadas e que serão tratadas a se guir. Rochas embrechïticas são subordinadas e têm cor cinza claro e semelhantes às descritas anteriormente, embora a granulação seja média e os porfiroblastos em geral não exce dam alguns milimetros. São compostos de microclina ou plagioclásio brancos. Os termos nebulíticos são cinzentos e de textura gnáissica fina. Os minerais presentes são o plagio- 


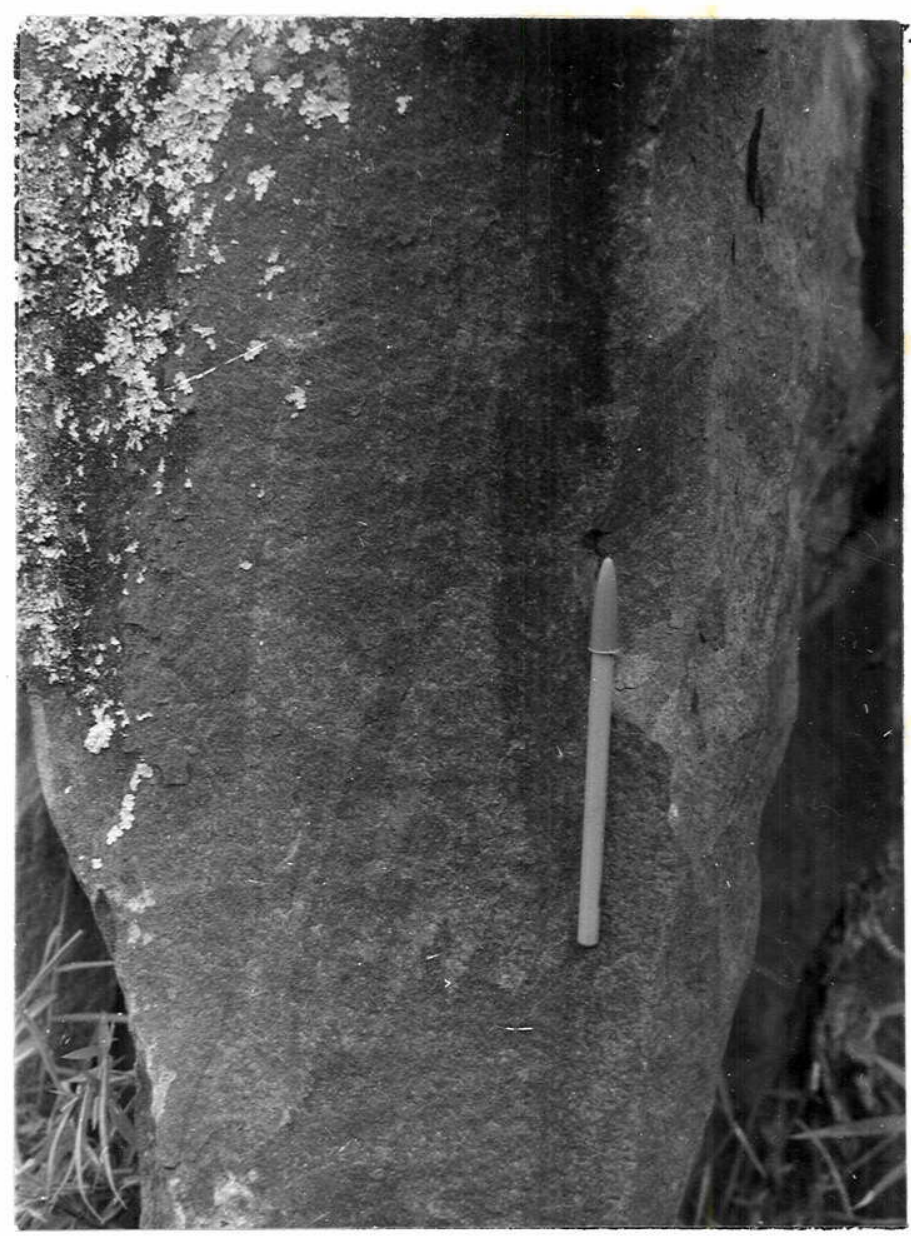

FOTO 5 - Estrutura nebulítica em rocha de granulação fina, biotítica. No centro da foto, a porção mais clara é pobre em máficos, conservando a textura gnäissica. Bairro da Água Soca, a $6 \mathrm{~km}$ da SP-50. 


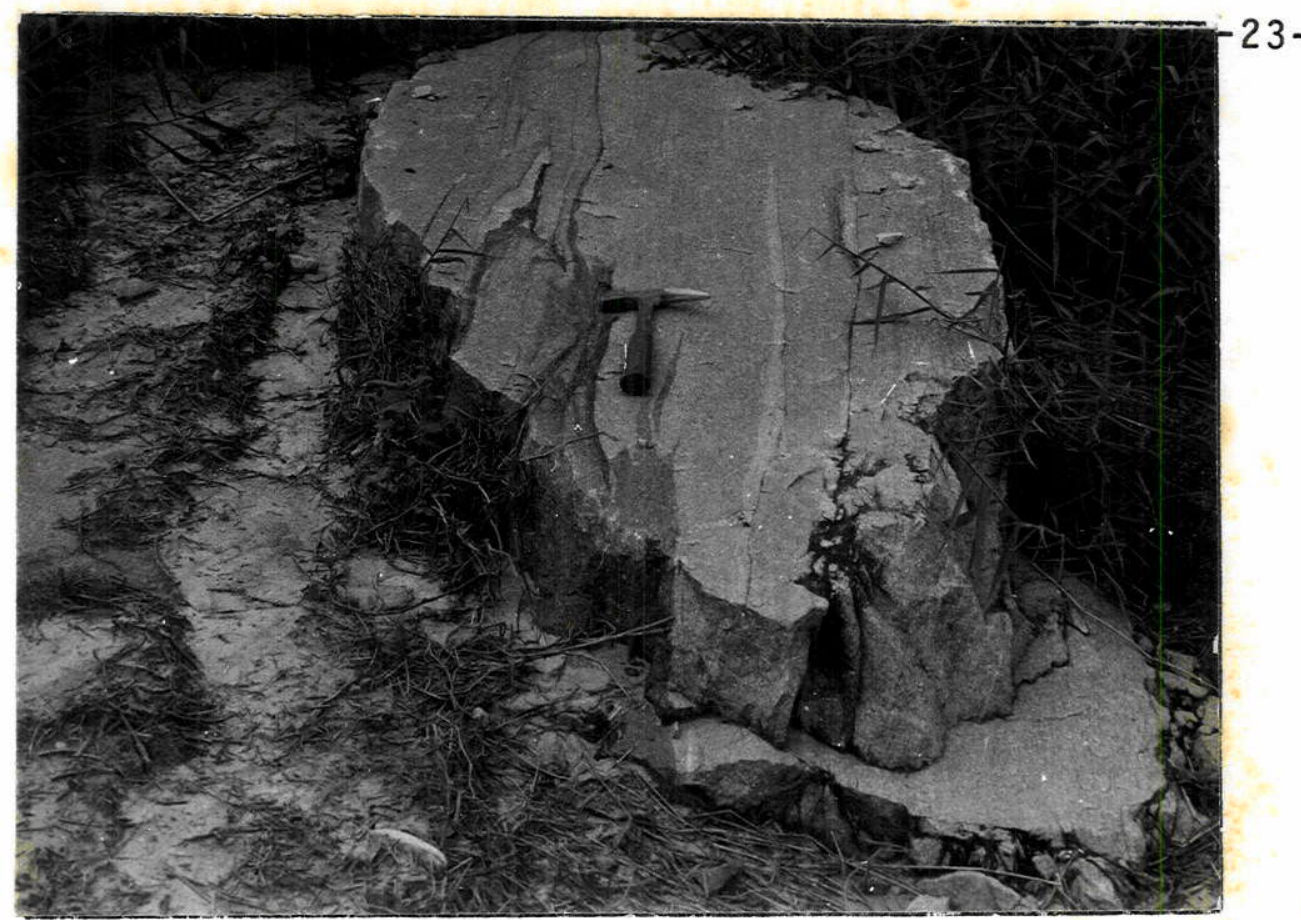

FOTO 6 - Concentrações "Schlieren" de biotita em rocha ho mogênea de textura gnäissica. Estas faixas são concordantes com a foliação da rocha. Bairro da Ågua Soca, a $4 \mathrm{~km}$ da SP-50.

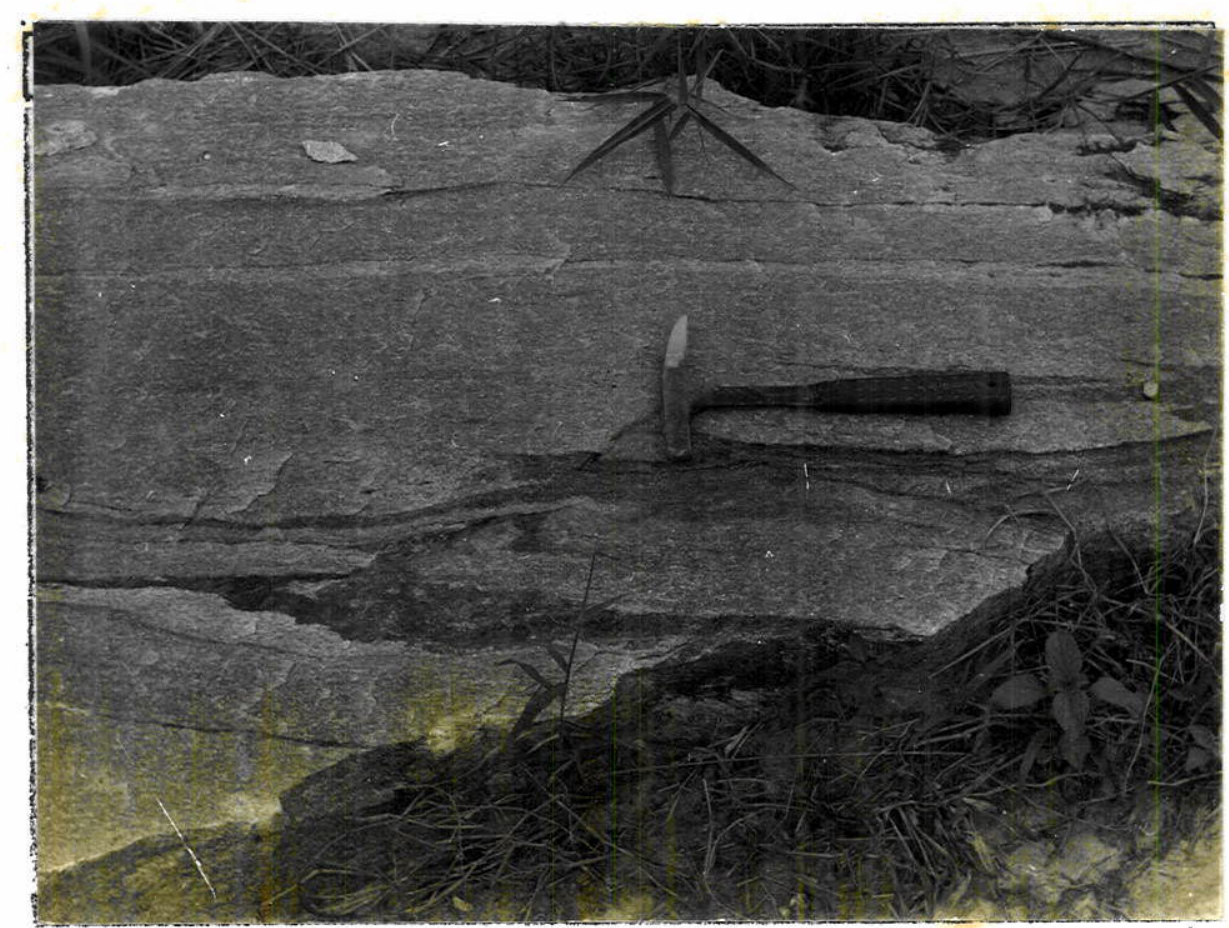

FOTO 7 - Pormenor da foto anterior, evidenciando a forma irregular das concentrações e as pequenas dobras que são desenhadas. 
clásio (oligoclásio), quartzo e microclina. Como acessórios tem-se a biotita, titanita, moscovita, apatita, allanita e opaco.

Intercalações de migmatitos estromatíticos de paleossoma xistoso e de anfibolitos foram verificados nos migmatitos e rochas granitóides do maciço do Roncador. As intercalações têm larguras métricas a decamētricas. São encontradas em cortes da estrada Rio do Peixe - Bairro da Agua Soca próximos à crista da Serra do Roncador.

No maciço da Agua Soca observamos intercalações de migmatitos estromatîticos bem como de leitos descon tỉnuos de quartzitos, centimétricos em largura.

\section{A. 3. Rochas Granitöides}

Nos maciços do Roncador e da Ägua Soca estão presentes rochas granitōides em associação intima com os migmatitos mais evoluídos. No maciço do Roncador são predominantes e é por esta razão e por relações de campo que o maciço foi classificado como corpo granitóide no Mapa Geoló gico.

No flanco sul do maciço do Roncador, a passa gem para os migmatitos estromatiticos è gradual, enquanto que na borda norte o contato é brusco, passando-se diretamente das rochas granitóides para os migmatitos heterogēneos estromatiticos de paleossoma xistoso. (vide Mapa Geoló gico).

As rochas granitóides são claras, em tonalidades que variam de bege a róseo cinzento. A granulação é média, podendo se tornar grosseira localmente, com porfiroblastos de microclina maiores que um centímetro. Em pontos restritos, uma orientação incipiente das micas se traduz nu 
ma quase isotropia da rocha.

Os minerais essenciais, microclina, quartzo e plagioclásio (oligoclāsio) encontram-se em arranjo imbri cado gnáissico a porfiroblástico, caracterizando dois tipos de rocha, que não foram separadas na presente escala de tra balho. Na primeira delas, que é tambēm mais comum, a biotita e a moscovita são dispersas mas orientadas (Foto 8), enquanto na outra são restritas a pequenas concentrações esparsas e sem orientação uniforme (Foto 9). As palhetas dispõem-se neste caso ao redor de porfiroblastos de microclina. Textura poiquiloblástica estā presente em alguns cristais de microclina. Os acessórios são epídoto e opacos.

\section{A. 4. Anfibolitos}

São rochas melanocráticas, de cor negra, gra nulação fina, textura orientada e em geral bastante fratura das constituīndo intercalações nos corpos maiores (vide Mapa Geolōgico). A sua alteração intempérica produz solos que de amarelados na proximidade da rocha, tornam-se de um vermelho escuro para a superfïcie do terreno. Crostas negras de óxidos de Mn recobrem muitos dos blocos de rocha dos a floramentos.

A composição mineral é essencialmente de hornblenda, plagioclāsio (labradorita) e quartzo, enquanto opaco, allanita e rara biotita são os acessōrios. Alofana foi encontrada em rocha das margens do Rio Turvo. As texturas são a granoblástica e a nematoblástica, com o anfibólio xenoblástico a subidioblāstico contendo muitas inclusões de quartzo. 


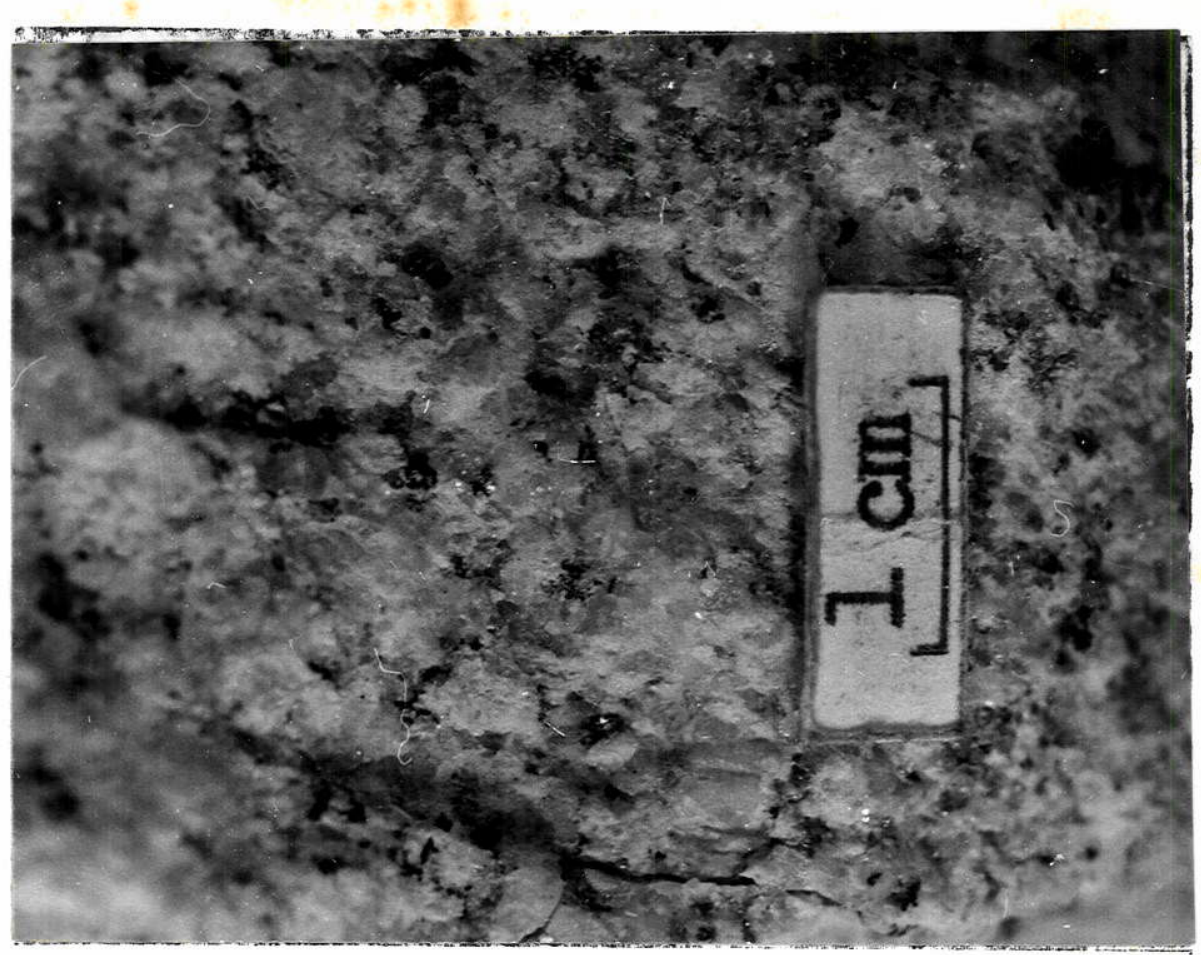

$-26-$

FOTO 8 - Rocha granitōide de granulação média apresentan do uma incipiente orientação das micas, textura gnäissica. Serra do Roncador, a da SP-50 (038546/SJ).

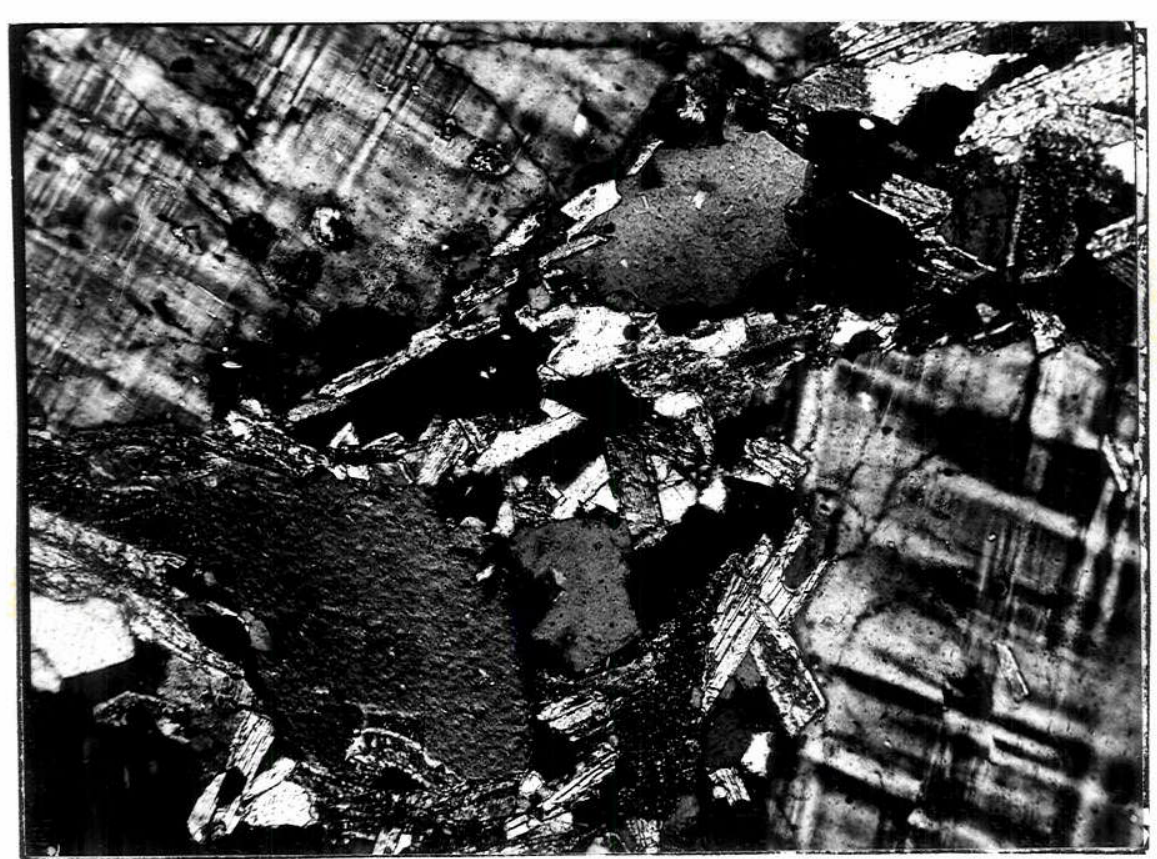

FOTO 9 - Fotomicrografia de rocha granitóide que contém porfiroblastos de microclina separados por lame las desorientadas e interrompidas de minerais placöides. O cristal porfiroblästico cinzento do canto inferior esquerdo é de moscovita trans versal à incipiente foliação da rocha. Serra do Roncador (038552/SJ). Nicois cruzados, $20 x$. 
B. BLOCOS SÃO JOSE dOS CAMPOS E SERRA DO JAMBEIRO

0 bloco Serra do Jambeiro apresenta rochas granitōides, essencialmente (vide Mapa Geológico). A simi laridade com rochas encontradas no bloco São José dos Cam pos levou-nos a descrevê-las em conjunto.

B.1. Rochas Migmatiticas

B.1.1. Migmatitos Heterogêneos Estromatíticos

São rochas bandadas onde o paleossoma xistoso e o neossoma de aspecto gnäissico se alternam em faixas de largura variável. O paleossoma é constituído de biotita, moscovita e quartzo em proporções variāveis, alēm de clorita, plagioclásio, apatita e opaco.

0 neossoma encontra-se em bandas milimétri cas a decimétricas concordantes com a foliação do paleossoma. Veios discordantes são mais raros. A composição do neos soma é feita essencialmente de quartzo, microclina e plagio clásio (oligoclásio) e como acessórios têm-se biotita, epídoto, allanita eopaco. A clorita é secundária.

0 aumento da possança das bandas de neossoma verifica-se localmente, como na região do Bairro Alto da Ponte, onde bolsões métricos de neossoma orientado chegam a incluir pedaços do paleossoma dobrado, numa estrutura agmatîtica. Um destes bolsões já foi explorado para extração de cautim.

Variações homogēneas nos estromatitos foram encontradas. Nestas zonas, a composição mineralögica é a mesma do neossoma, apenas com mudanças na quantidade relativa dos minerais. 
Do mesmo modo, quartzitos, quartzitos calcosilicāticos e frações xistosas foram observadas. Os quartzitos são semelhantes aos encontrados no bloco Monte ro Lobato, enquanto que os xistos são constituídos de biotita, moscovita, quartzo, sillimanita e granada e têm como acessōrios plagioclásio, zircão e epỉdoto. Os sillimanita xistos situam-se nas faldas da Serra do Palmital (173526/ SJ), Foto 10 .

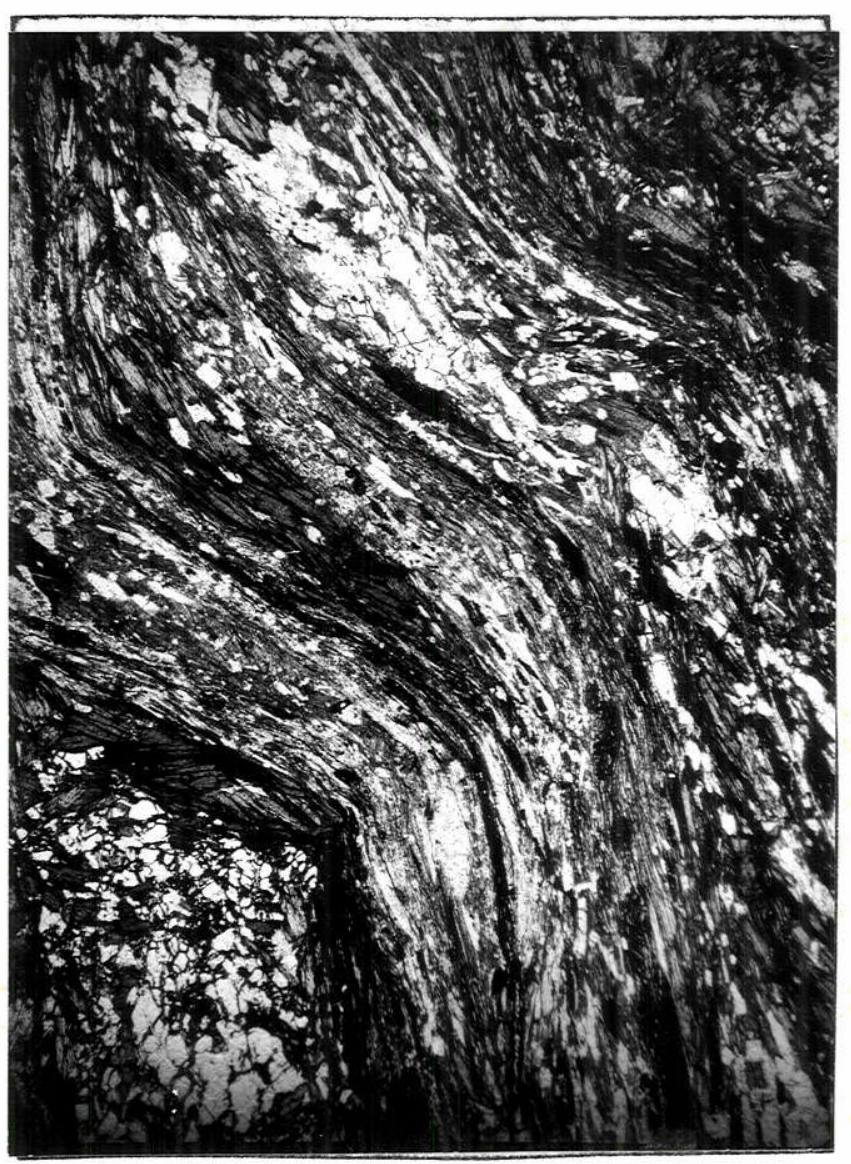

FOTO 10 - Fotomicrografia de sillimanita xisto levemente crenulado. As bandas claras são de sillimanita fibrosa, as escuras de biotita e os agregados granulares, de quartzo. Fazenda Santana, flanco SE da Serra do Palmital. Nícois cruzados, $20 \mathrm{X}$. 
Três ocorrências de rochas homogêneas estromatiticas e de composição global granítica foram mapeadas no bloco são José dos Campos. Formam corpos restritos no seio dos migmatitos heterogēneos regionais, e ocorrem nas proximidades da estação Jaguari da RFF, na região de Vila Cândida e mais para nordeste, na região do Ribeirão Pedregu Tho (Vide Mapa Geológico).

São rochas bandadas de textura gnāissica e porfiroblastos ocasionais de microclina. As bandas escuras e claras são dadas por variações no conteūdo de māficos. A composição global granitica é dada pela presença de microclina e quartzo, com proporções variáveis dos acessórios biotita, moscovita, plagioclásio (oligoclásio), apatita,zir cão, granada e opaco, aos quais se adiciona a clorita como mineral secundārio.

B.1.3. Migmatitos Homogêneos Estromatiticos e Embrechíticos de Composição Tonalitica

Os migmatitos homogêneos estromatíticos de composição tonalîtica estão presentes no bloco são José dos Campos formando duas faixas alinhadas, situadas na região da Serra do Palmital e a sudoeste do bairro do Buquirinha (Vide Mapa Geológico). Este ūltimo corpo prolonga-se para SW, passando pela barragem do Rio Jaguari, jā na folha de Igaratā. o carāter distintivo destes corpos em relação aos demais migmatitos homogêneos estromatîticos é a composição tonalitica. 
Na região da Serra do Palmital, estes migmatitos constituelii-se em rochas de granulação média, localmen te fina.

A estrutura é bandada (Foto 11 ), onde as ban das cinzentas são predominantes em relação ãquelas mais ricas em minerais fémicos, de cor branca. Por efeito de alteração, estas bandas claras tornam-se amareladas.

A rocha possui textura gnáissica onde se desenvolvem de modo difuso pequenos porfiroblastos de plagioclásio (oligoclásio) que não excedem um centỉmetro, de forma elipsoidal e orientados segundo a foliação (Foto 12). Os minerais essenciais são quartzo e plagioclásio (oligoclá sio). Biotita parcialmente cloritizada, moscovita, apatita, zircão, epídoto e granada são os acessórios.

Texturas granoblástica e poiquiloblástica são comuns, esta ūitima dada por cristais poiquiloblásticos de moscovita desorientados ou pelo quartzo dentro de plagio clásio. Os porfiroblastos de plagioclásio são contornados pelas biotitas, que ficam dispostas ao seu redor. De modo mais restrito, foi encontrado crescimento antipertitico em plagioclásio, textura em moldura e halos pleocroỉcos nas biotitas que envolvem zircão.

Uma intercalação de diopsîdio - tremolita quartzito foi amostrada na Fazenda do Meio, no flanco sul da Serra do Palmital (153511/SJ). A rocha, de coloração cin za esverdeada, é composta de quartzo, calcita, moscovita, plagioclásio (andesina), diopsídio e tremolita-actinolita; os acessórios são a titanita, epīdoto e microclina. A micro clina concentra-se no neossoma, que tem textura granoblásti ca. As bandas mais quartzîticas são também granoblāsticas, enquanto que as mais ricas em biotita possuem textura gnáis sica. 


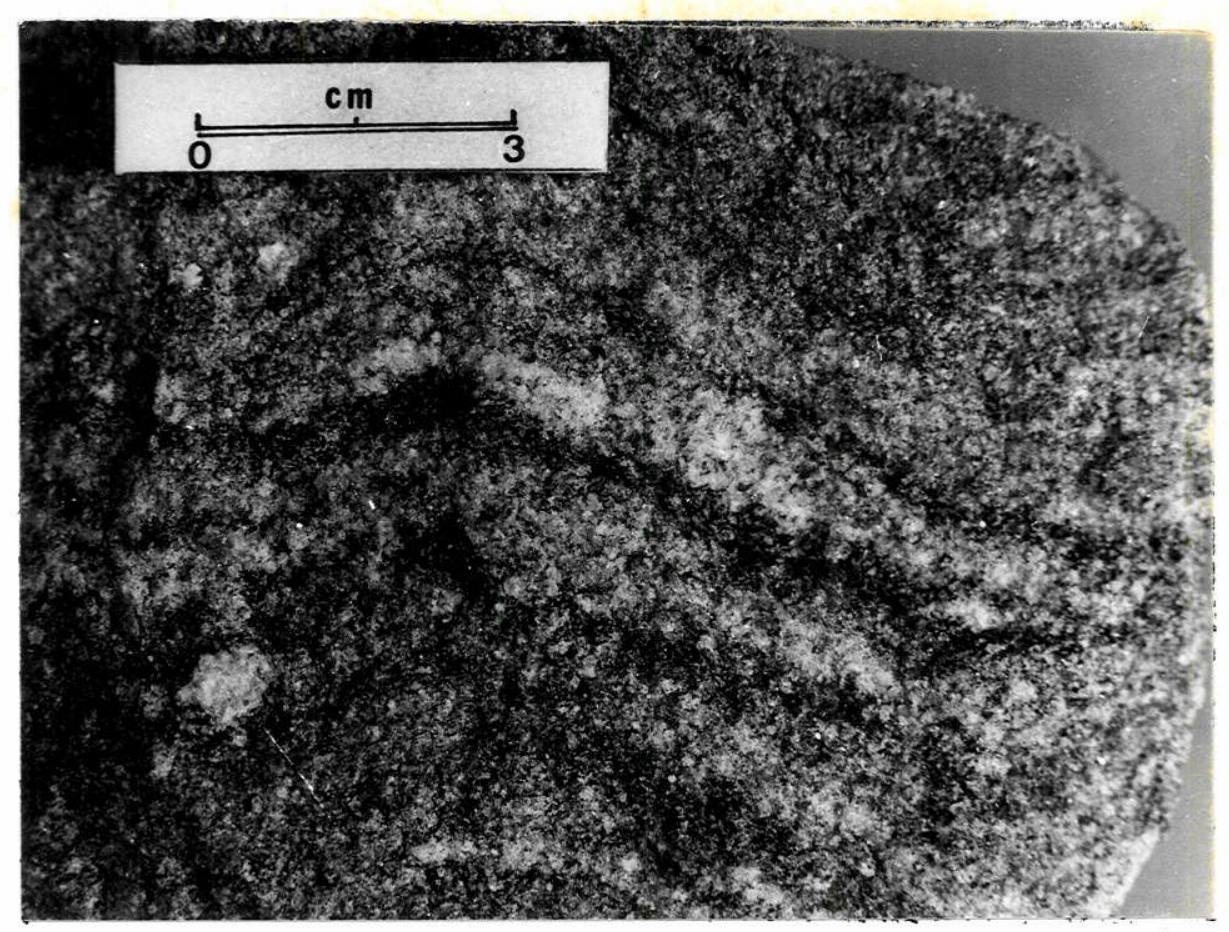

FOTO 11 - Estromatito homogêneo tonalítico desenhando uma do bra aberta. Bairro do Buquirinha, 5,5 km a NNE da Vila Cândida (086449/SJ).

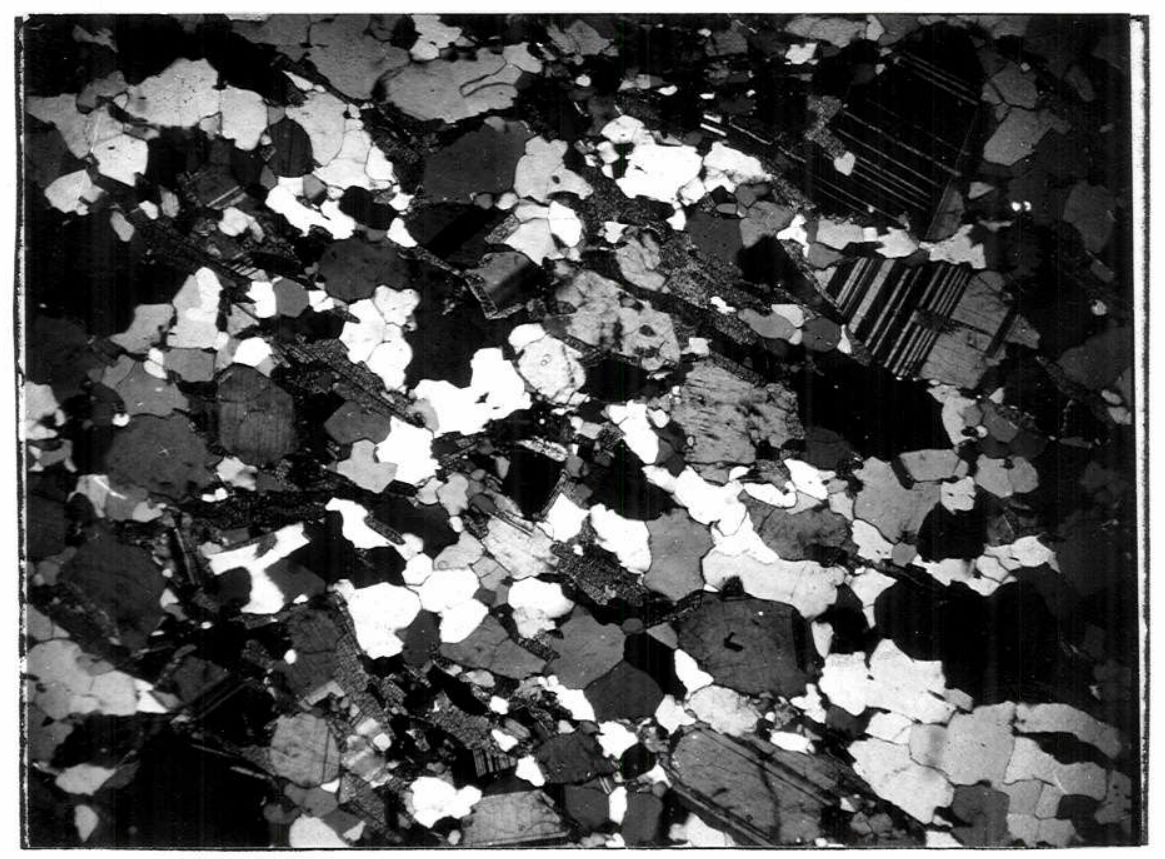

FOTO 12 - Fotomicrografia do estromatito homogêneo tonalitico. O feldspato presente è o plagioclásio (oligo cläsio). Região da Serra do Palmital, a $1 \mathrm{~km}$ da se de da Fazenda da Jaca. Nicois cruzados, $20 x$. 
A faixa de migmatitos homogêneos embrechīticos prōxima ao Rio Jaguari encerra rochas onde a estrutura oftalmītica é tīpica. A rocha tem coloração cinza com felds patos brancos em porfiroblastos de até 5 centimetros de diâa metro (Foto 13 e 14). O neossoma e o paleossoma têm aspecto gnāissico e dispõem-se em bandas concordantes entre si, no interior das quais desenvolvem-se os ocelos elipsoidais.

Na parte mais próxima ao falhamento do Buquira, os porfiroblastos são de plagioclāsio (oligoclásio), e mais raramente de granada. A granulação da matriz varia de média a fina, e os componentes essenciais são o plagio clásio (albita-oligoclásio), quartzo, hornblenda e biotita. os acessórios são moscovita, granada, titanita, zircão, cal cita, epídoto e apatita. Textura poiquiloblástica é observa da nos cristais de plagioclásio, que englobam hornblenda e quartzo. A orientação dos minerais placóides não é uniforme pois encontram-se circundando os porfiroblastos e há mos covitas totalmente desorientadas. Mirmequita e textura em moldura podem estar presentes.

Na parte mais ao sul, próxima ao Rio Jagua ri, os porfiroblastos de granada são mais abundantes e maio res, atingindo atē 8 milīmetros de diâmetro. Dobras ptigmáticas do neossoma são visiveis nos afloramentos.

B.1.4. Migmatitos Homogêneos Embrechiticos e Nebuliticos

As cristas da Serra do Palmital são sustenta das por migmatitos homogêneos de composição granitica a adá mellitica. As estruturas presentes são a embrechītica e nebu litica, sendo raros os tipos bandados. Afloramentos podem ser visitados na estrada que atravessa a parte mediana da serra. 


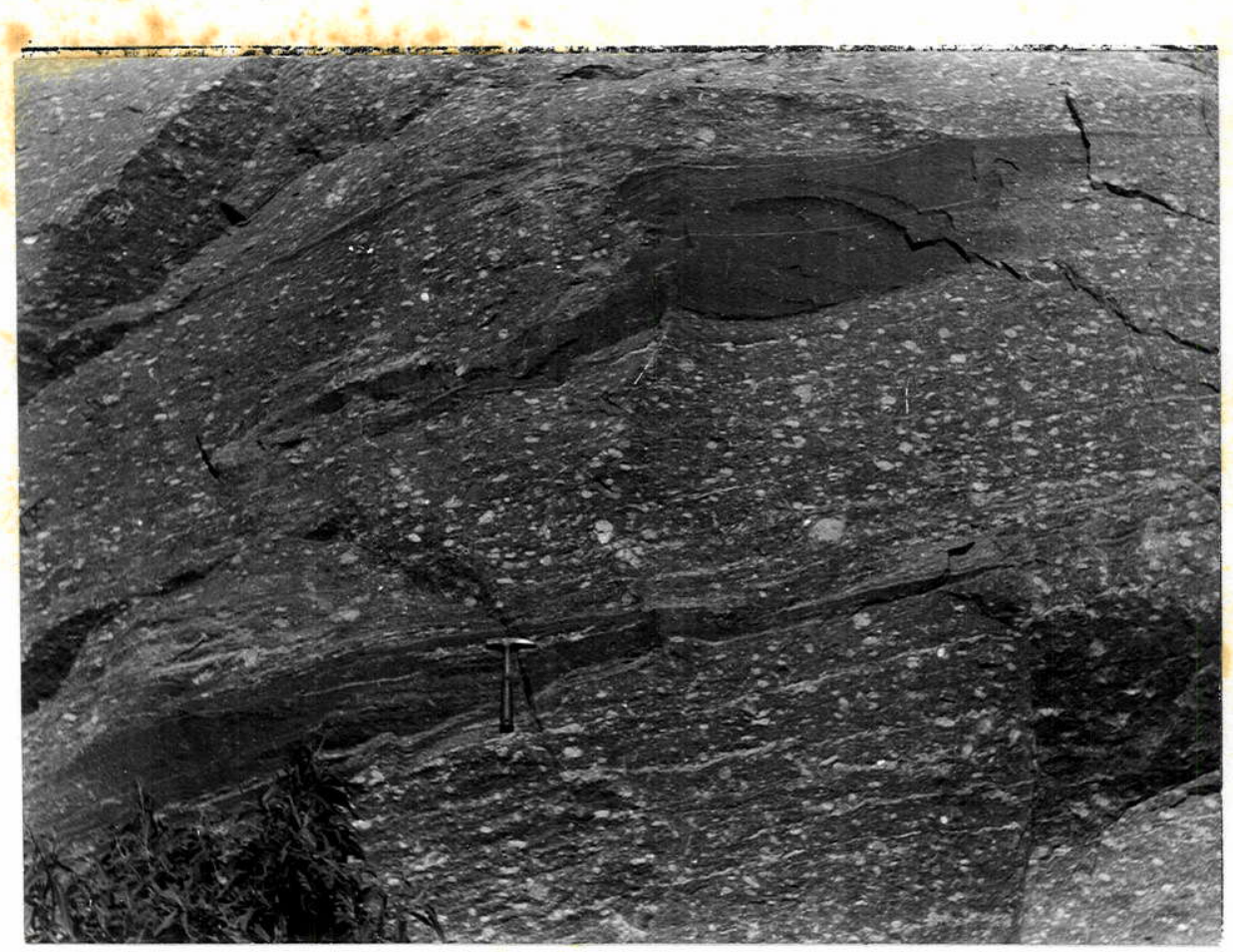

$-33-$

FOTO 13 - Estrutura oftalmítica nos migmatitos homogêneos de composição tonaliftica. As zonas escuras, não afetadas pela feldspatização, são ricas em hornblenda. Pedreira da barragem do Rio Jaguari, a $1 \mathrm{~km} \mathrm{NE}$ do vertedouro de concreto ( $957353 / \mathrm{IG}$ ).

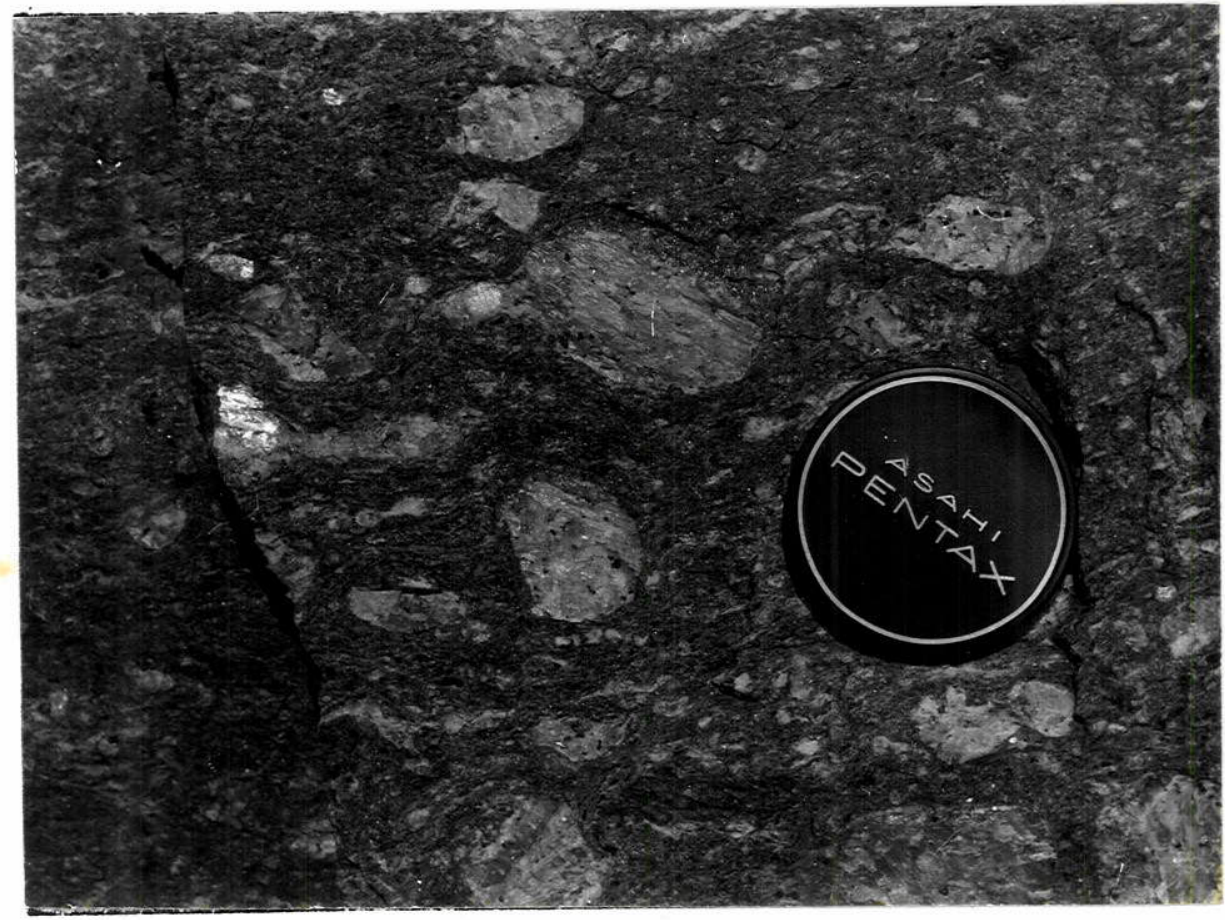

FOTO 14 - Pormenor da foto anterior. Os porfiroblastos de plagioclásio (oligoclásio) contêm diminutos cristais de hornblenda, que também aparece na. matriz. Pedreira da Barragem do Rio Jaguari. 
A presença de microclina na matriz e nos por firoblastos diferencia estes tipos rochosos dos migmatitos homogêneos adjacentes para os quais a passagem ē gradual. A granulação é mais grosseira, a coloração é cinza médio e os porfiroblastos são maiores, alcançando três centīmetros de comprimento dos elipsōides. A mineralogia é a mesma, apenas com o acréscimo da microclina (Foto 15 ).

A orientação das micas é pronunciada, por contornarem os cristais porfiroblásticos. As texturas predo minantes são a porfiroblástica e a gnäissica, com incipiente foliação.

B.2. Rochas Granitóides

o bloco Serra do Jambeiro é constituĩdo, na folha estudada, por rochas granitóides de estrutura oftalmi tica, similares às do bloco são José dos Campos que afloram no vale do Rio Putins.

Os granitóides tipo Serra do Jambeiro são de granulação média a grossa, cor cinza-claro, com texturas gnāissica e embrechítica (oftalmītica) pronunciadas. Os por firoblastos de forma elipsoidal são contornados pelas micas, deformando a foliação e seu tamanho médio é de 2 a 3 milimetros de comprimento, podendo ultrapassar um centíme tro localmente.

A mineralogia essencial é quartzo, microclina e plagioclásio (oligoclásio). Os acessórios mais comuns são biotita, titanita, apatita, zircão, opaco, granada e calcita. Clorita e Sericita podem aparecer como secundārios. As texturas em moldura, mirmequítica e poiquiloblástica fo ram reconhecidas. 0 quartzo tem extinção ondulante, exceto nos cordões alongados, talvez produtos de recristalização. 


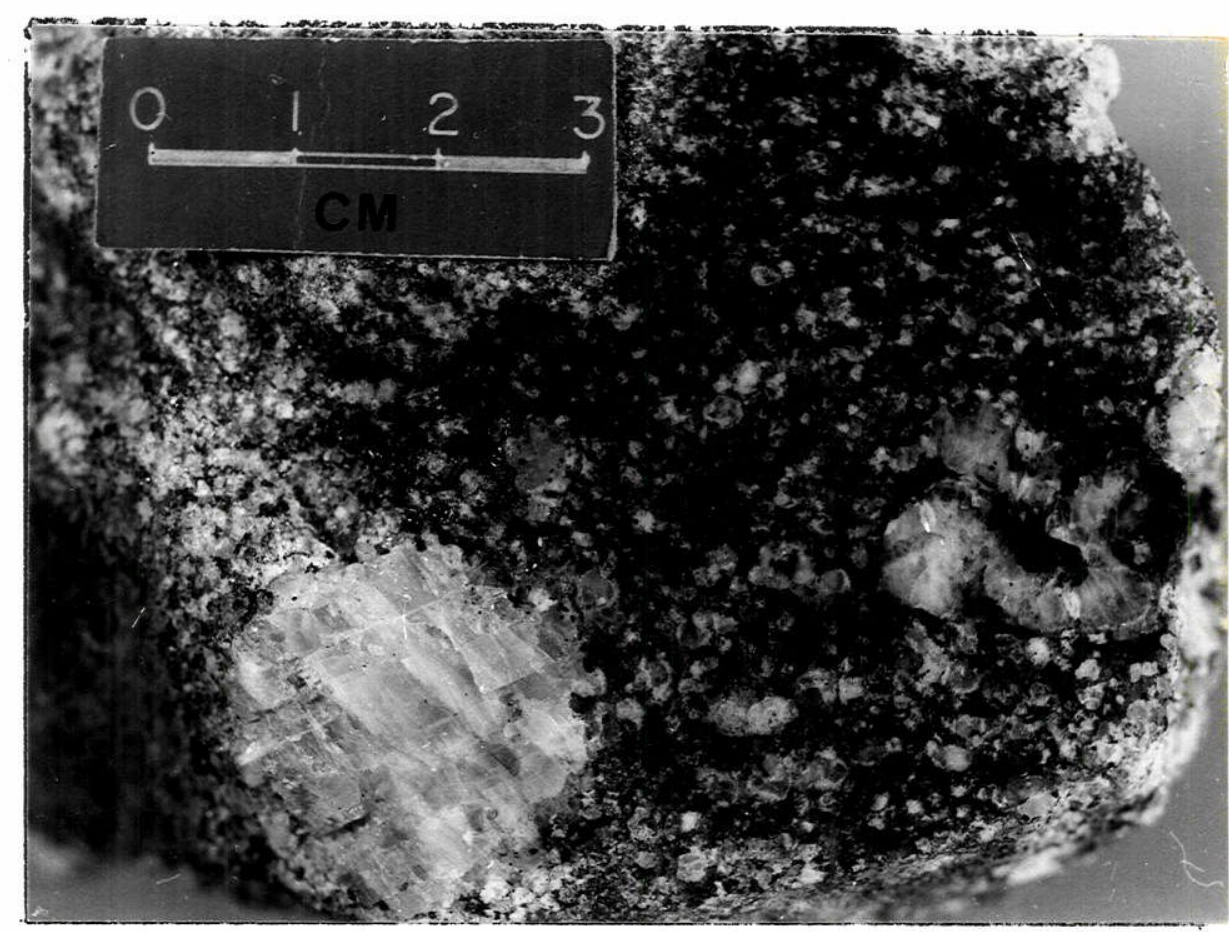

FOTO 15 - Embrechito de composição granítica. A matriz é pouco orientada e se destaca o porfiroblasto de microclina. Fazenda do Gazola, Serra do Pal mital $(150528 / \mathrm{sJ})$. 
$\mathrm{Na}$ pedreira do Serrote, situada alēm dos limites da folha de São José $(204273 / J C)$, verificamos a existência de intercalações de anfibolito e de "boudins" de quartzito.

o caráter parcialmente intrusivo dos corpos de rochas granitóides é indicado pela falta de contatos gra duais para as encaixantes, onde foi possível a observação.

\section{BLOCO BENGALA}

\section{C.1. Migmatitos}

C.1.1. Migmatitos Homogêneos Estromatíticos e Embrechiticos

Estas rochas bandadas ocorrem em uma faixa adjacente à Falha do Rio Jaguari. São separadas dos migmati tos mais evoluídos a sul por estreita zona de falhamento transcorrente.

São rochas de cor cinza médio a claro, granu lação fina a média, com porfiroblastos de feldspato bege es branquiçado. Nas lâminas verifica-se que os porfiroblastos são de microclina ou plagioclásio (oligoclásio), em uma matriz composta de quartzo, microclina e plagioclásio (oligoclásio). Biotita, apatita, opaco, zircão e epīdoto são aces sōrios.

As micas orientam-se segundo a foliação, porém contornam os porfiroblastos. O aspecto bandado é dado pela alternância de faixas mais micāceas de textura gnäissi ca com faixas de texturas granoblästica e porfiroblāstica onde os minerais placóides são mais raros. Mirmequita e tex 
tura em moldura podem ser observadas, assim como a prešença de intercrescimento pertítico na microclina e antipertitico no plagioclásio.

\section{C.1.2. Migmatitos Embrechiticos}

Incluindo diversos fácies, alguns dos quais correspondem aos migmatitos homogêneos bandados, a ārea de migmatitos mais evoluídos situada no bloco Bengala apresen ta afloramentos nas encostas marginais ao Córrego do Bengala e na estrada que do Bairro do Morro Podre leva a São José dos Campos.

Os termos mais homogêneos possuem texturas gnäissica e porfiroblástica nas associações de ortoclásio (opticamente: $X \Lambda A \simeq 80$ e $2 V \simeq 600$ ), plagioclásio (0ligoclāsio) e quartzo. Os acessōrios são biotita, hornblenda, apatita, moscovita, zircão, epídoto e titanita. A clorita, mineral secundārio, é uma peninita. A moscovita é poiquilo blástica, enquanto os porfiroblástos são de microclina e plagioclásio e podem atingir três centỉmetros de diāmetro, numa matriz de granulação média a fina. Não é comum a textú ra em moldura ao redor de porfiroblastos. Os agregados de quartzo e feldspato são granoblásticos (Foto 16).

A textura gnáissica pode estar mascarada pe los porfiroblastos contornados por micas, das quais a biot $\underline{j}$ ta encontra-se muitas vezes cloritizada.

Faixas bandadas homogēneas foram verificadas em afluentes do córrego do Bengala,tanto a sul (022456/ SJ), como a norte (046470/SJ). No afluente a sul (Foto 17), a rocha exibe granada, sillimanita, biotita, quartzo e plagioclásio (oligoclásio), enquanto o feldspato potássico,epi doto e opaco são acessōrios. A sillimanita é idioblástica, 
podendo ser poiquiloblástica com quartzo no interior. A gra nada forma porfiroblastos de até um centīmetro, assim como os de feldspato, estes ūitimos podem estar circundados por textura em moldura. Dobras ptigmāticas, estruturas dobradas e de transposição (Foto 18) foram ainda verificadas nos a floramentos.

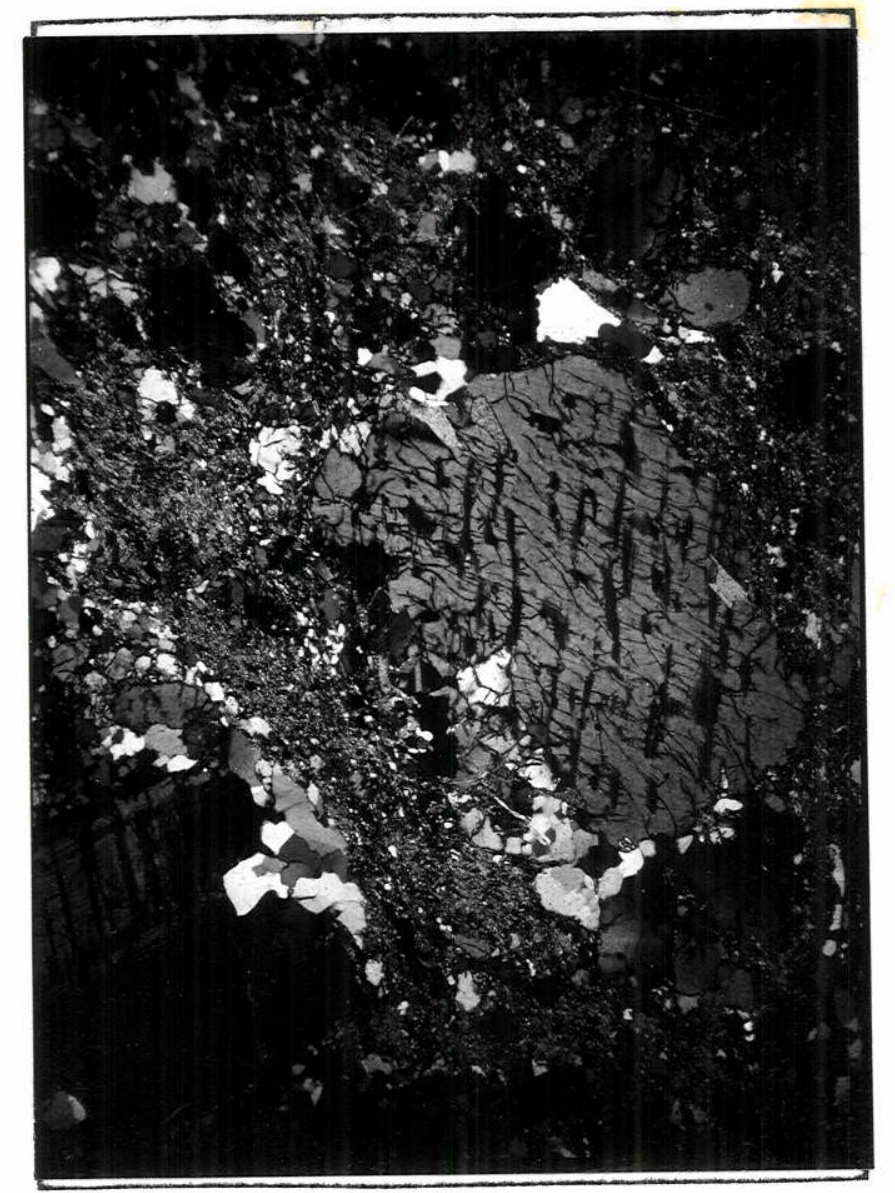

FOTO 16 - Fotomicrografia de embrechito exibindo porfiro blasto de plagioclásio antipertítico rodeado de cristais de quartzo, numa matriz biotitica, bastante orientada. Bairro do Morro Podre, $500 \mathrm{~m}$ a SE do Ribeirão Piúva. Nícois cruzados, $20 x$. 


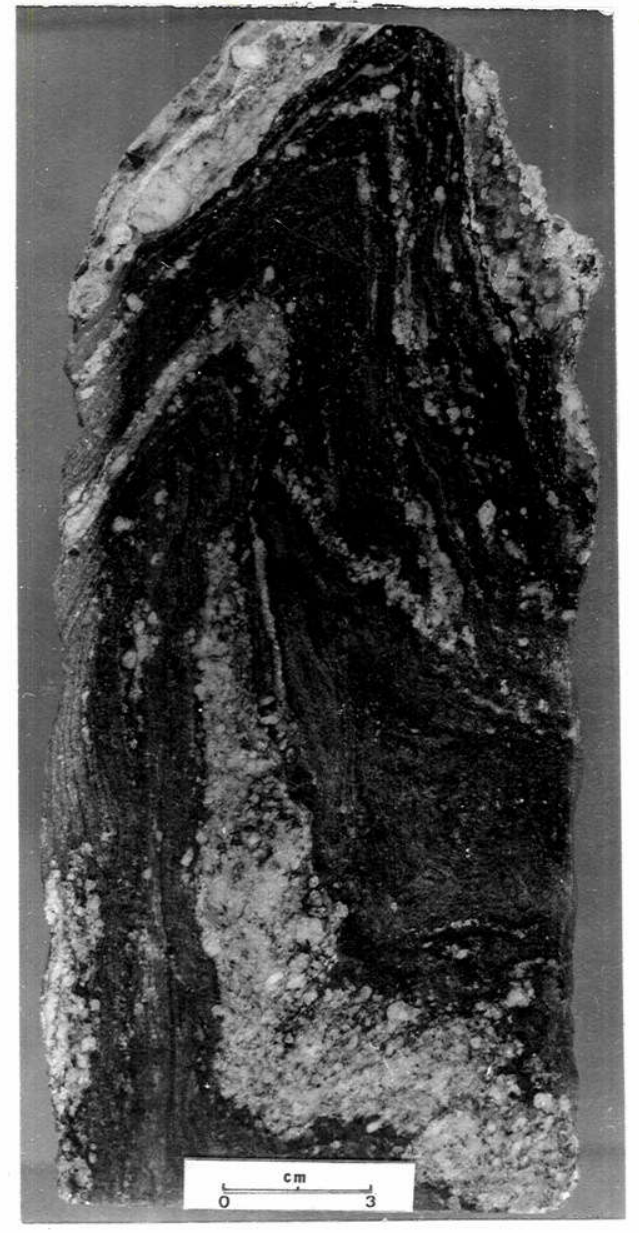

$-39-$

FOTO 17 - Estrutura dobrada em estromati to homogêneo. Nas bandas de neossoma encontram-se numero sos porfiroblastos de microclina. Bair ro dos Freitas, a sul do Cörrego do Bengala (022456/SJ)

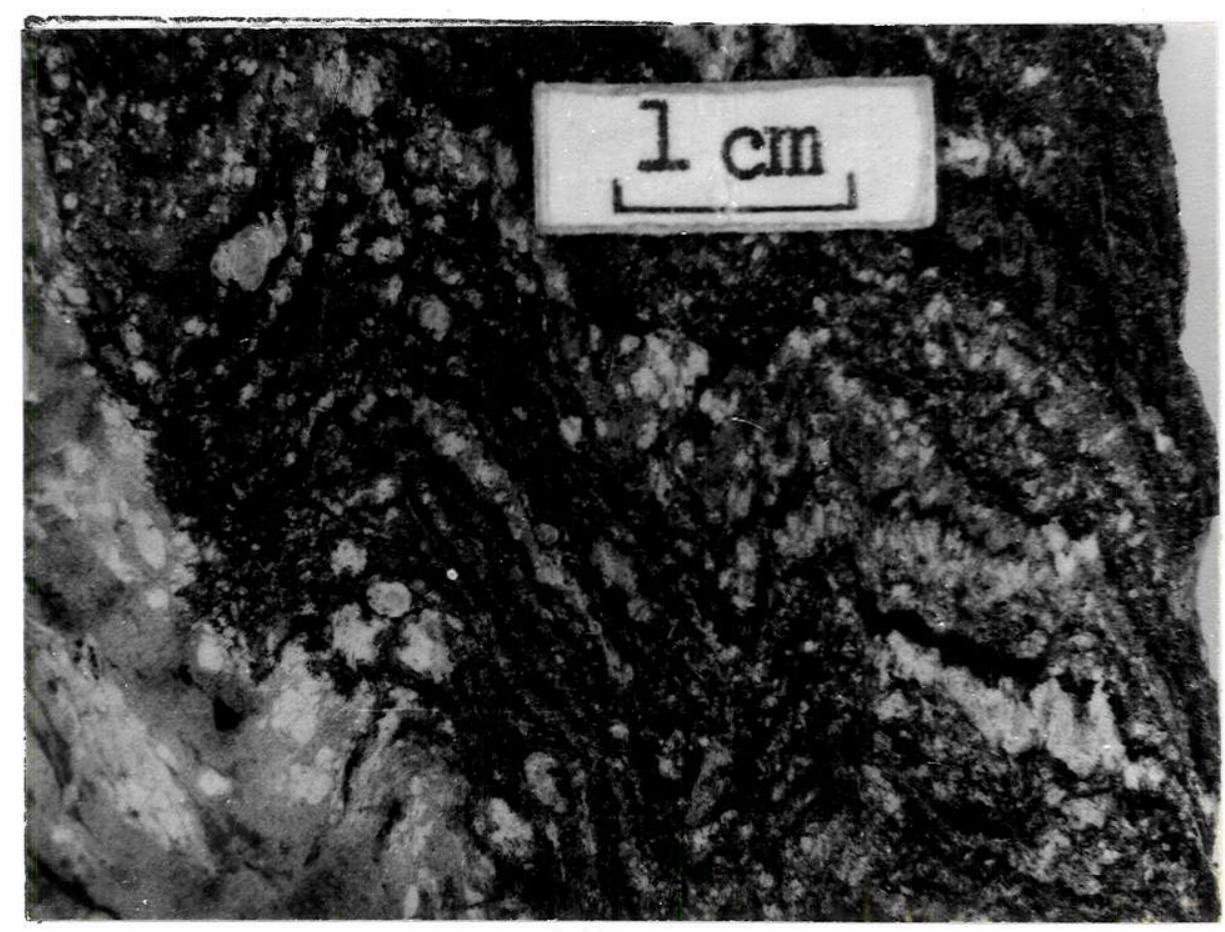

FOTO 18 - Estrutura microdobrada no embrechito com sillima nita e granada, gerada por planos de crenulação muito pröximos. Bairro dos Freitas, a sul do Cör rego do Bengala $(022456 / \mathrm{SJ})$. 


\section{C.2. Granulitos}

São rochas homogêneas, de aspecto maciço a fo liado, com coloração cinza-escura. Encontram-se localmente migmatizadas mostrando então estruturas bandada e venulada.

A granulação é fina a média e os minerais essenciais são o quartzo,clinopiroxênio, hornblenda, plagioclāsio (labradorita) e biotita (Foto 19). A titanita, orto piroxēnio, zircão, apatita, opaco e granada são acessórios e a clorita é secundāria. Os fêmicos apresentam arranjo gra noblástico, enquanto as micas e anfibólios encontram-se sub orientados, dando uma textura gnáissica. Textura em moldura é restrita.

Evidēncias de retrometamorfismo foram obtidas: o piroxênio associa-se a anfibōlio, em alguns cristais com seção de piroxênio. Noutros cristais, manchas de piroxênio restam no interior do anfibōlio. Da mesma maneira, a biotita associa-se ao anfibōlio.

Existem cordões de quartzo (quartzo discóide) sem a extinção ondulante que os caracteriza na matriz, além de deformação de cristais de plagioclásio por planos de cizalhamento.

0 neossoma encontrado nestas rochas restringe se a faixas claras facilmente perceptiveis macroscopicamente. O feldspato potássico, branco ou levemente esverdeado, quartzo e plagiociásio organizam-se em texturas porfiroblás tica e gnáissica, com a orientação dada por bandas de quart zo e alguma biotita. 
$-41-$

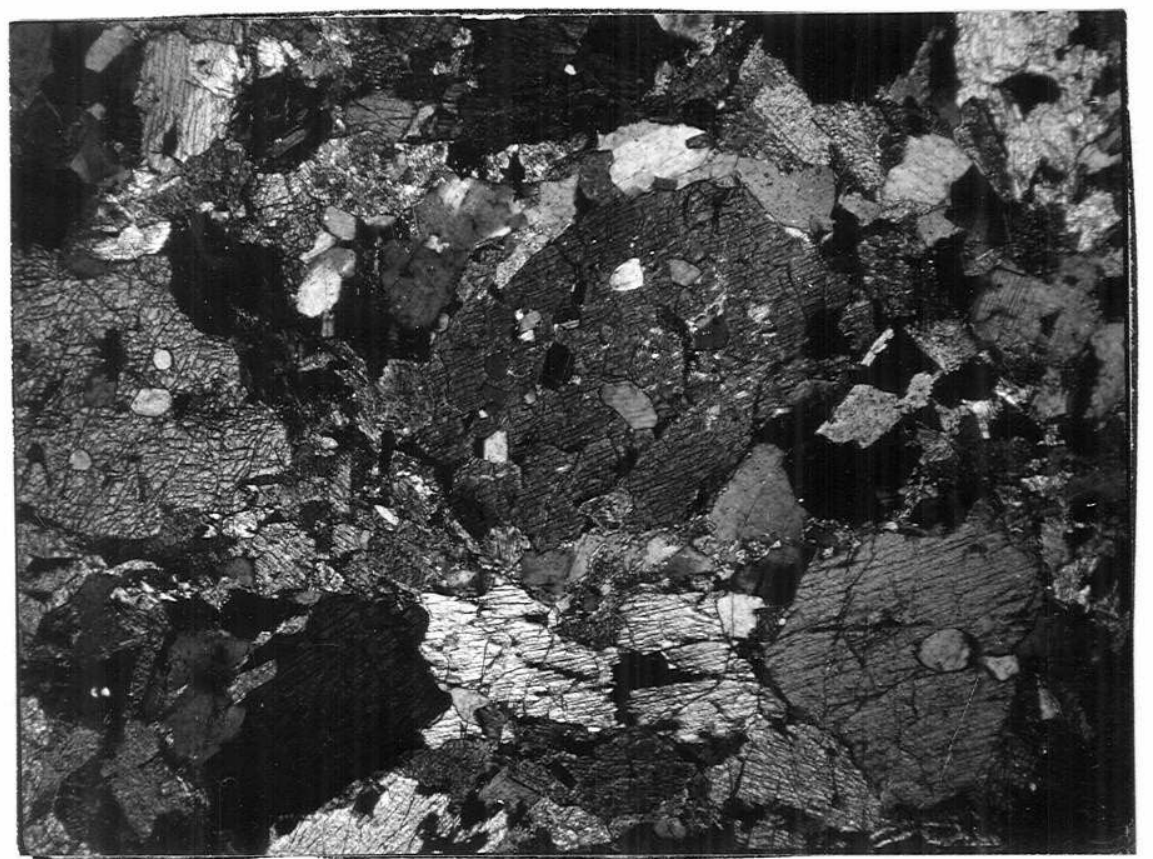

FOTO 19 - Fotomicrografia de granulito com textura poiquilo blästica nos cristais de clinopiroxênio que englo blam grãos de quartzo e de plagiocläsio. Bairro dos Freitas, estrada que leva ao cörrego do Benga la. $(024450 / \mathrm{sJ})$. 
Na ārea estudada vārios falhamentos foram ve rificados no terreno, dentre os quais as zonas de falhamento transcorrente do Rio Jaguari e do Buquira constituem as mais expressivas faixas de milonitização.

A cataclase atingiu de modo relevante os mig matitos homogêneos e rochas quartzíticas, originando faixas onde a moagem foi mais intensa, intercaladas a outras, onde o esmagamento foi menos acentuado. Estas faixas têm espessu ras centimétricas a métricas, somando-se em larguras de cen tenas de metros atē quase $2 \mathrm{~km}$.

As rochas originadas pelo processo dinämico de moagem têm sua mineralogia e estrutura diretamente relacionada à composição mineral da rocha primária e ao grau de destruição sofrido pelos constituintes.

Os termos petrogräficos foram classificados de acordo com a intensidade de milonitização em brechas tectónicas, protomilonitos, milonitos, ultramilonitos e blastomilonitos (Higgins, 1969), dos quais os protomiloni tos e milonitos são os termos mais abundantes.

As brechas tectônicas (Foto 20) representam o início do processo de cataclase, caracterizado pelos crís tais fraturados, atravessados por planos de cizalhamento e com bordos granulados. Nos protomilonitos, a textura em mol dura aparece ao redor de antigos porfiroblastos e é alongada segundo as faixas compostas da farinha resultante do esmagamento de zonas menos resistentes. Nos protomilonitos de rivados de rochas migmatiticas, as micas e o quartzo são os primeiros minerais a serem destruídos. 


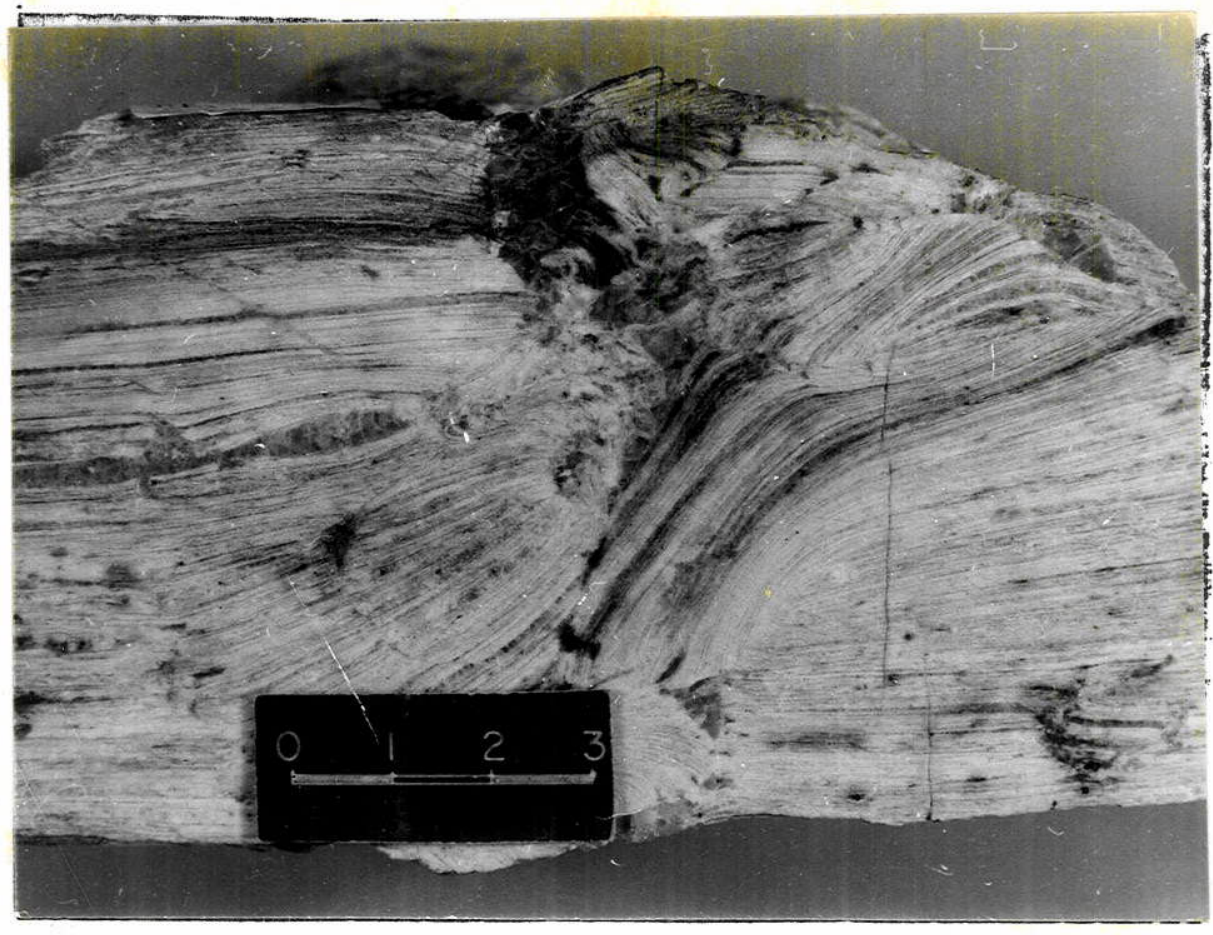

$-43-$

FOTO 20 - Brecha tectônica desenvolvida em rocha quartzíti ca com bandas feldspáticas (microclina) e moscoviticas subordinadas. A presença de quartzo recristalizado é acentuada. Rodovia SP-50, região do Bairro da Agua Soca $(077496 /$ SJ).

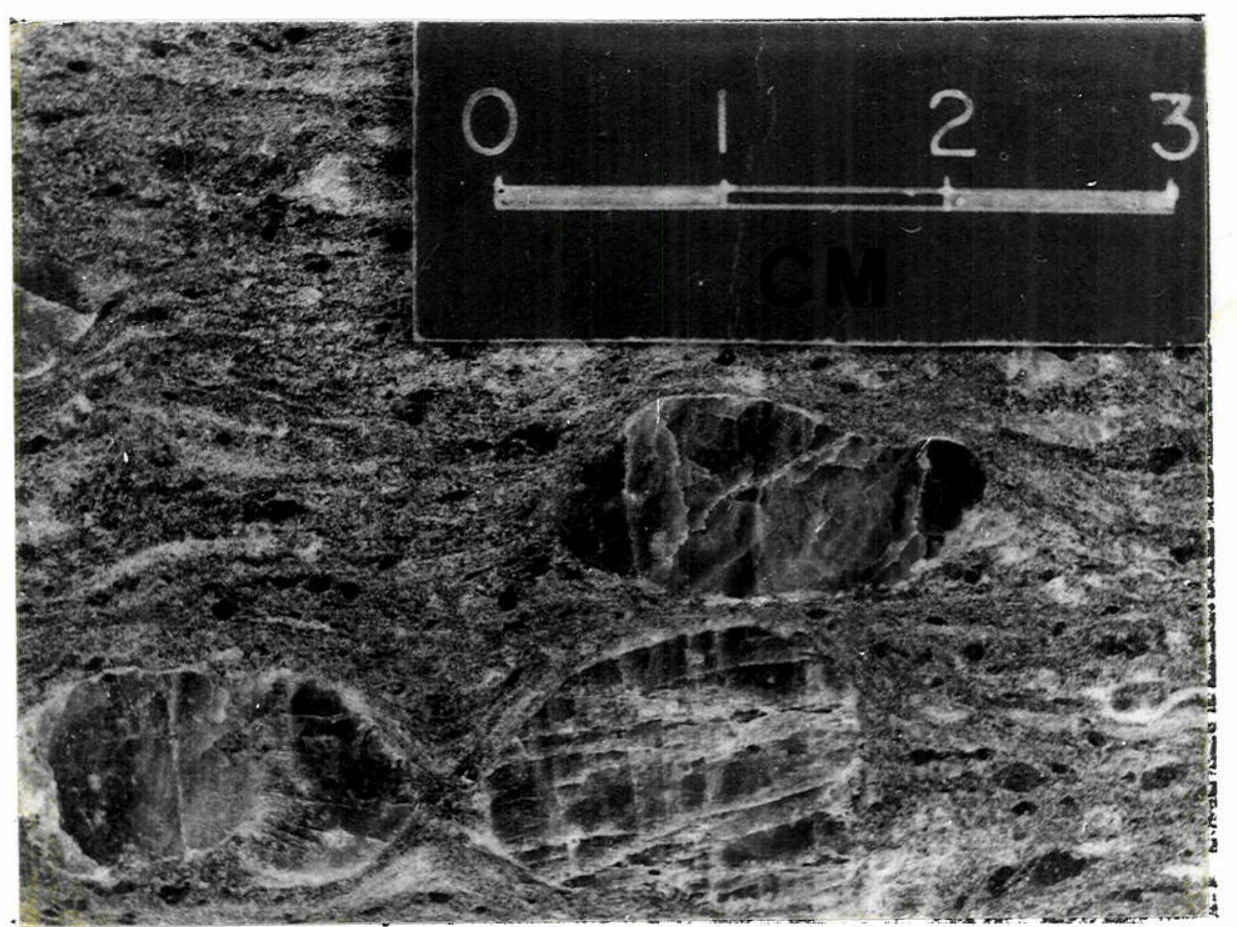

FOTO 21 - Detalhe de protomilonito ocelar que mostra. os porfjroclastos emolduradospor quartzo moído,bran co. Os pontos negros são porfiroclastos de hornblenda. Região da Fazenda Santa Luzia(997395/SJ), estrada Bairro do Caetë-Barragem do Rio Jaguari. 
Bairro dos Freitas e da região da Fazenda Santa Luzia, os minerais presentes são o quartzo, plagioclásio (albita a oligoclásio), biotita e hornblenda, com os acessórios tita nita, apatita, allanita e opaco. A rocha é melanocrātica, cinzenta, com foliação conspícua dada por faixas de mine rais moidos intercalados com zonas de quartzo recristaliza do. Próxima aos porfiroclastos de plagioclásio e hornblenda, a foliação sofre ondulações, contornando-os. A biotita é dividida em minúsculas palhetas que tendem a se orientar segundo a foliação (Foto 21 ).

Os porfiroclastos exibem extinção ondulante, assim como os cristais de quartzo möido. Não apresentando tal característica, o quartzo em cordões forma lâminas milimétricas em espessura, enquanto que os porfiroclástos de forma arredondada ou elipsoidal chegam a ultrapassar trés centỉmetros de diāmetro.

Os protomilonitos ocelares acima descritos são profundamente semelhantes em composição mineralógica e estrutura, aos migmatitos homogéneos embrechiticos da re gião da barragem do Rio Jaguari, situados no Bloco São José dos Campos, o que sugere uma origem a partir destas rochas. O dominio destes protomilonitos na Falha do Buquira éa SW do bairro Ponte do Costinha.

Nas faixas onde é menor a quantidade de oce los de feldspato, as zonas menos afetadas são constituídas de quartzo e feldspato estirados, formando lamelas concordantes com a foliação e com os cordões de quartzo.

Os milonitos (Foto 22) são rochas onde 0 processo de moagem reduziu a uma farinha mais de $50 \%$ dos componentes da rocha, criando uma massa de foliação pronun ciada onde se intercalam grãos e cordões de quartzo recris talizado e fenoclastos de feldspatos (microclina e plagioclāsio) que tendem a sofrer diminuição de tamanho. Os dimi 


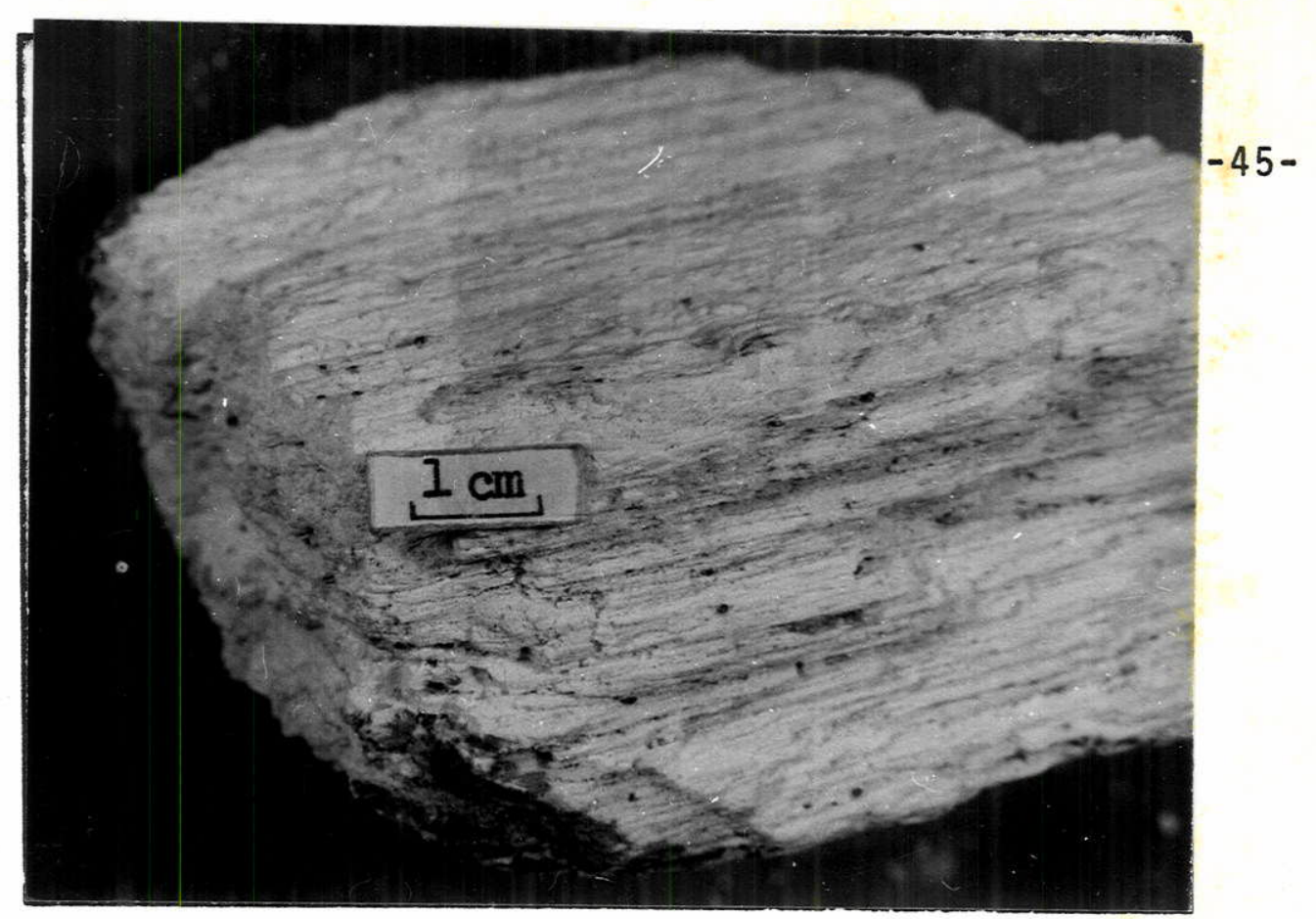

FOTO 22 - Milonito com foliação cataclästica pronunciada. A face superior da amostra é paralela à folia ção e contém numerosas lineações. Bairro do Cae té, $500 \mathrm{~m}$ a NW do Cörrego do Pau-de-Saia(02042W SJ).

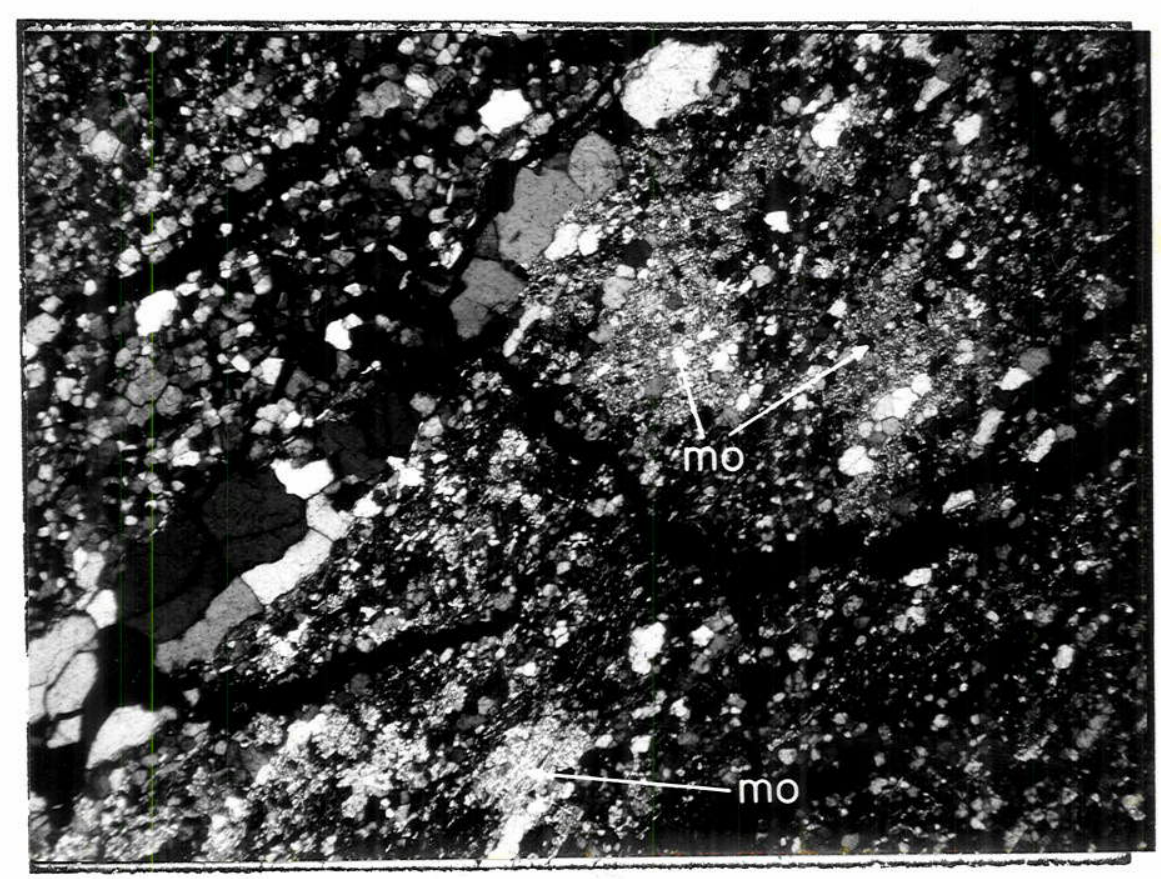

FOTO 23 - Porfiroblastos desorientados de moscovita poiqui loblástica (mo) em milonito parcialmente decomposto. O cordão de quartzo não tem extinção ondu lante e é paralelo à foliação da rocha. Rodovia SP-50, a $1 \mathrm{~km}$ da ponte sobre o Rio Taquari no bairro homônimo. Nícois cruzados, $25 x$. 
nutos cristais de biotita estão muitas vezes cloritizados e os cristais de titanita, opaco e apatita tendem a manter seu pequeno tamanho. Os blastomilonitos são restritos na área, e sua distinção para com os milonitos se faz pela maior intensidade de recristalização do quartzo.

Moscovita porfiroblástica e poiquiloblástica é encontrada englobando cristais de quartzo, dentro da poeira microscópica que constitui os milonitos (Foto 23).

Ultramilonitos que se assemelham a quartzoxistos de granulação muito fina foram registrados em al guns pontos da ārea estudada. Meso e macroscopicamente, os milonitos e ultramilonitos possuem conspícuas lineações in dicativas da movimentação.

Granada e sillimanita não foram encontradas nas zonas de falhamento, à exceção de um afloramento, situado na estrada que leva do Cōrrego Pau-de-Saia à reprêsa do Rio Jaguari (005409/SJ), onde o quartzo e plagioclásio da matriz do milonito estão intensamente fragmentados e recristalizados, aparecendo em lamelas, com pequenos cristais alongados e de bordas muito intimamente interlobadas. os porfiroclastos são de feldspato e granada, enquanto as sillimanitas são idioblásticas a subidioblásticas. Os agre gados de sillimanita, fibrosos, dão uma lineação nas zonas cinzentas da rocha bandada.

No interior das zonas de falhamento foram observados blocos e megablocos de quartzito que ao microscópio não se revelam afetados pela milonitização em grau significativo. São ocasionais os planos de cizalhamento cortando estas rochas, constituídas de quartzo branco a cinza claro, onde ocasionalmente se vêm porfiroblastos de microcitina (Foto 24).

Nos afloramentos, os quartzitos acham-se. 


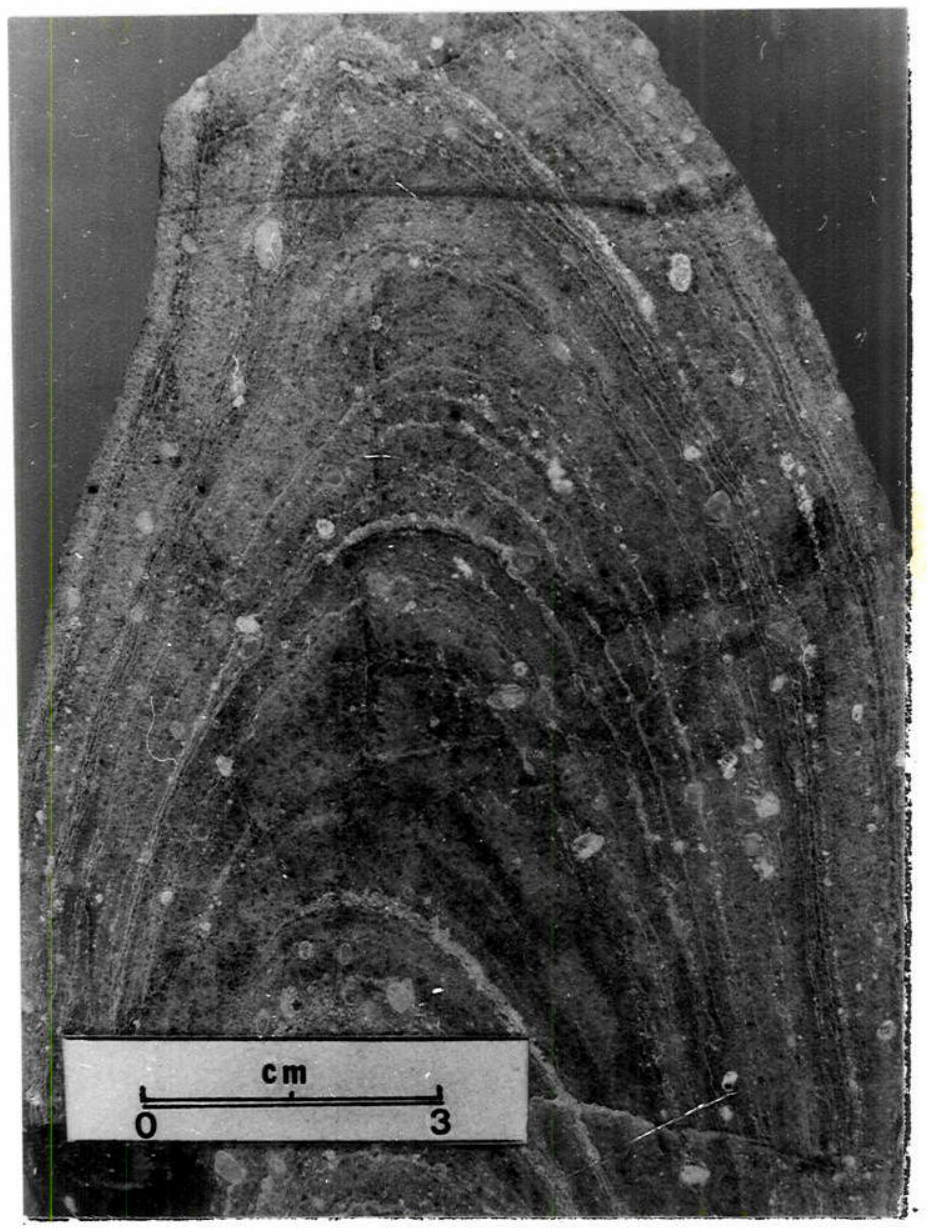

FOTO 24 - Apice de dobra em quartzitos do interior do Falhamento do Buquira. Os por firoblastos de microclina são dispersos e afetam a estratificação reliquiar. Fazenda Santa Maria, $1 \mathrm{~km} a$ sul da SP-50 (081478/SJ). 
configurando āpices de dobras, centimétricas a decamétri: cas, que parecem ter sido preservados como zonas mais resis tentes à cataclase (Foto 24 ).

4. Rochas Intrusivas Bāsicas

Rochas intrusivas aparecem em pontos restritos que na presente escala de mapeamento foram apenas indicados no mapa. Foram encontrados 5 corpos concordantes com a foliação dos metamorfitos encaixantes e que se situam prō ximos à zona de falha do Rio Jaguari ( 2 corpos) ou no interior da zona de falha do Buquira ( 3 corpos), Foto 25.

A granulação é média a fina, em tipos melano cráticos, de cor negra, com pontos brancos de plagioclásio espalhados no interior da rocha. A textura é a ofitica,cons truīda por augita, plagioclásio (andesina), olivina e hor $\underline{n}$ blenda. Os acessórios são biotita e mineral opaco enquanto a clorita é secundāria. Os cristais de piroxēnio e mineral opaco são euhédricos, menores que os de olivina, também eu hedral a subhedral. Os cristais de plagioclásio são subhedrais e por vezes apresentam-se zonados.

\section{Sedimentos Terciārios}

A cobertura sedimentar que assoreou a bacia de Taubatē é composta de duas sequências detríticas (Almeida 1955): a inferior é predominantemente pelitica, destacadamente incluindo camadas de folhelhos pirobetuminosos fossilïferos e de cor geralmente esverdeada, entre camadas maciças de argilas bentoniticas. A formação superior constitui-se de uma associação de conglomerados, arenitos, arcósios, siltitos e argilitos em camadas descontinuas, lenticu lares e interrompidas na vertical (Suguio, 1969). 


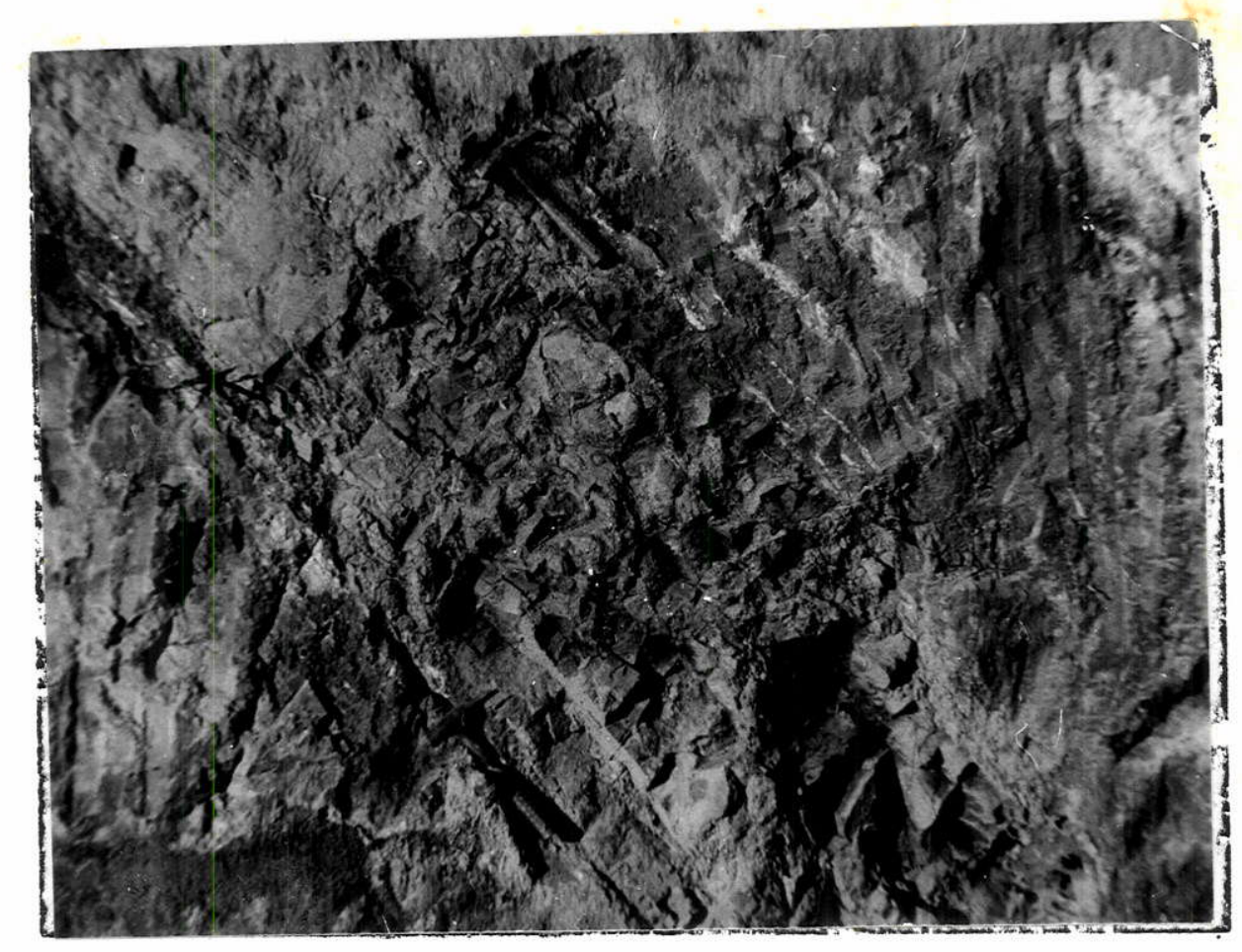

FOTO 25 - "Sill" de diabäsio em milonitos do Falhamento do Buquira. Região da Fazenda Santa Luzia, (995393/SJ) estrada Bairro do Caeté-Barragem do Rio Jaguari. 
Na folha de São José dos Campos não foram re conhecidos sedimentos referíveis à formação inferior, que parece ser subsuperficial, pelo exame de dados de sondagens. A maior parte dos autores admite uma discordância plano paralela separando esta unidade da superior (Almeida, op. cit.). No corte do $\mathrm{km} 333$ da Estrada de Ferro da RFF, entre Taubaté e Pindamonhangaba, a literatura faz referéncia a seixos de sedimentos argilosos da formação basal, no pacote superior.

A formação superior está representada na qua drỉcula (vide Mapa Geolögico) por camadas de sedimentos are no-argilosos de cores pálidas, bege a amareladas, que se al ternam com leitos de argilas de cores também pálidas e variadas: brancas, amarelas, vermelhas, roxas e verdes. $\mathrm{Na}$ maior parte dos afloramentos a argila é avermelhada. Os sedimentos arenosos contêm pequenos seixos de quartzo e quart zito, bolas de argila branca a cinza e cristais de feldspatos agora intemperizados. A matriz é de areia média a fina, e os seixos têm em média 1 a $2 \mathrm{~cm}$, localmente excedendo 5 $\mathrm{cm}$ de diâmetro.

A alternância que se verifica entre as camadas, as cores distintas e a resposta diferencial à erosão emprestam aos afloramentos um aspecto bandado, relativamente uniforme e repetitivo (Foto 26). Ocorrências localizadas de niveis lateriticos irregulares foram encontradas.

Nas bordas setentrionais da Bacia, a sedimen tação se deu em condições mais enérgicas, desenvolvendo con glomerados grosseiros, com seixos, blocos e até matacões de quartzitos, quartzo de veios e rochas granitóides, de um metro de diámetro ou maiores. Os afloramentos onde tais conglomerados estão presentes situam-se no bairro Alto da Ponte e em alguns cortes da estrada que segue a margem norte do Rio Jaguari. 


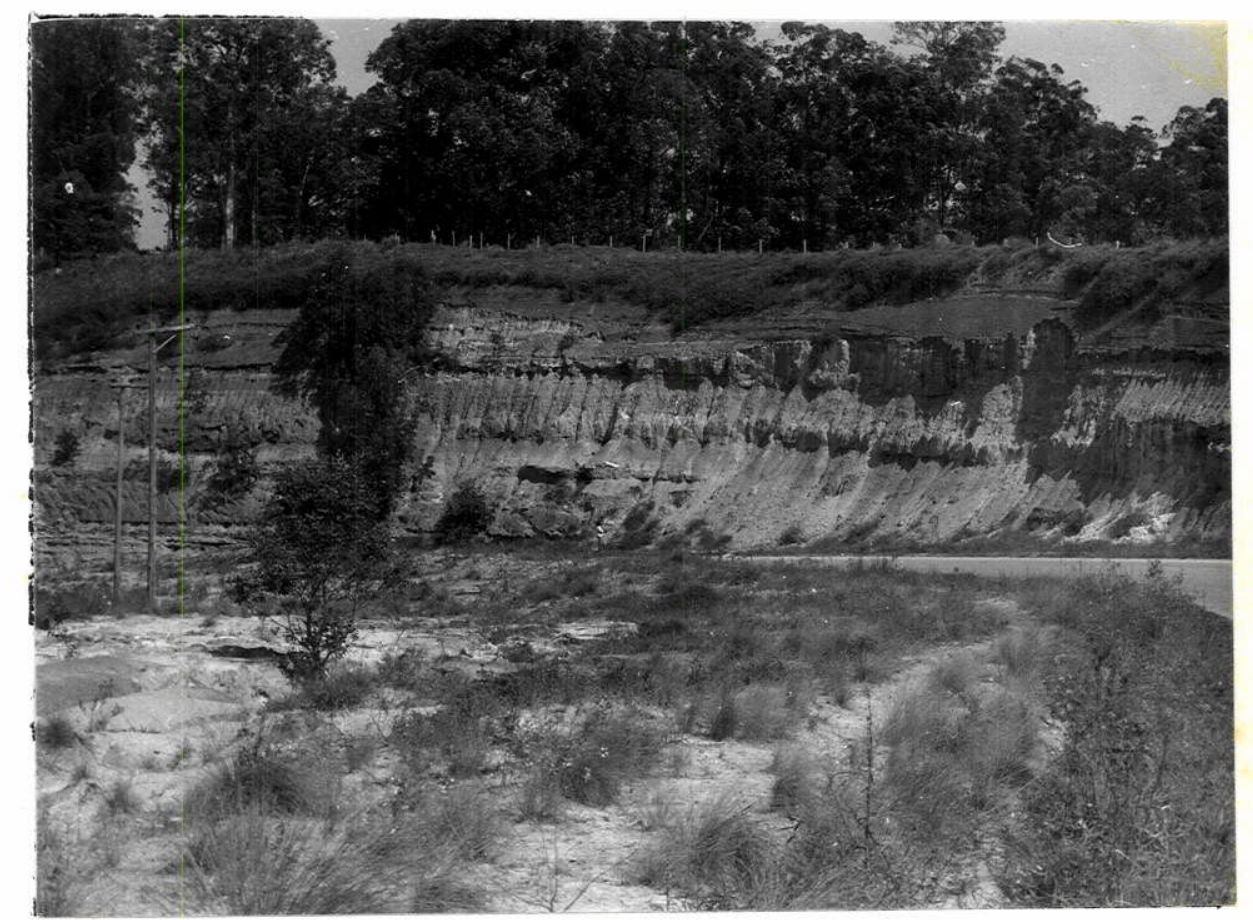

FOTO 26 - Camadas sedimentares da Bacia de Taubaté no Compartimento Paratei. A atuação de processos erosi vos sobre o corte de estrada acentua as diferenças litológicas. Estrada de acesso à Barragem do Rio Jaguari, a $4 \mathrm{~km}$ da Rodovia Presidente Dutra. 
6. Sedimentos Modernos

Os sedimentos quaternārios estão ligados à

rede de drenagem atual, particularmente aos vales dos rios Paraiba do Sul, Buquira e Jaguari (vide Mapa Geológico). Situam-se em niveis de atê 60 metros abaixo dos afloramentos mais elevados dos sedimentos terciārios (Freitas, 1956).

São depósitos inconsolidados silto-argilosos de cores pālidas, bege a amarelados. Incluem localmente blocos de rocha pouco arredondados que se expõem às épocas de chuvas torrenciais pela lavagem e remoção dos finos (Queiroz L.P.de, informação verbal). Distribuem-se em terraços fluviais e de pedimentação (Ab'Saber e Bernardes, 1956).

A região de São José dos Campos acha-se situada na primeira das três regiões sedimentares definidas por Verdade et al. (1961), ao longo do vale do atual Paraíba do Sul. Nessa região os sedimentos são mais finos e aparecem com frequēncia solos ricos em matēria orgānica, localmente formando turfeiras (Verdade e Hungria, 1966). 


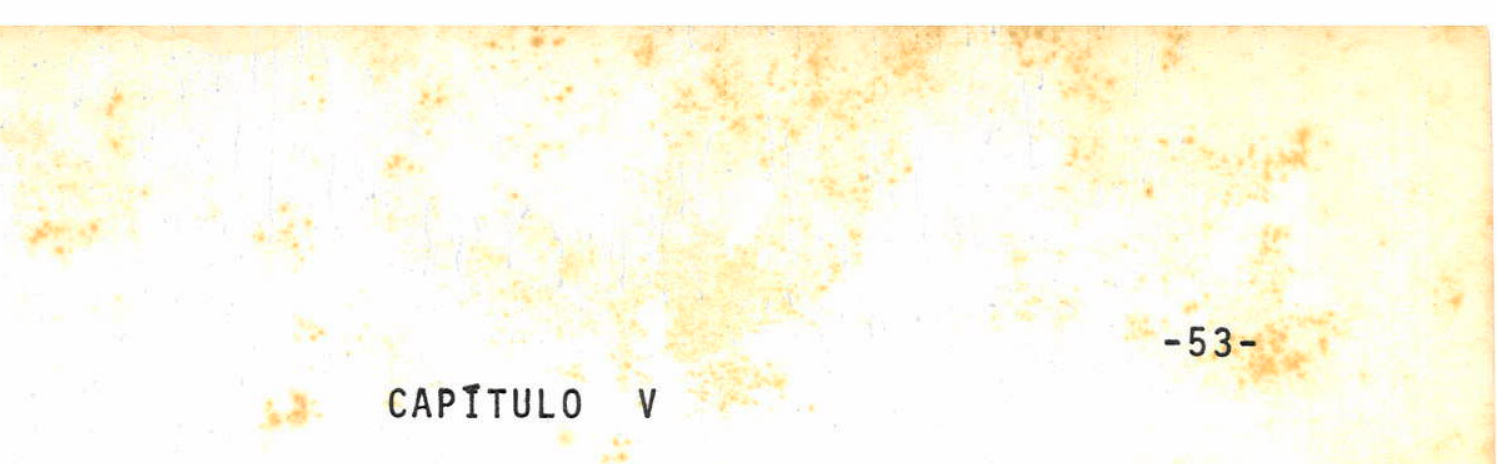

ESTRATIGRAFIA

As sequēncias metamōrficas que constituem o arcabouço geolögico da região Leste do Estado de São Paulo têm sido relacionadas aos Grupos Açungui e São Roque (Pré Cambriano Superior) e ao Complexo Cristalino ou Complexo Gnäissico-Migmatītico.

0 Grupo Açungui não mais tem sido considerado como de natureza essencialmente ectinitica. Rochas migma tîticas foram incluỉdas no Grupo Açungui (Hasui, 1973) com base em semelhanças estruturais, metamōrficas e de magmatís mo entre rochas daquele grupo e do Complexo Cristalino. Esta inclusão permitiu separar dois conjuntos litológicos: o Complexo Ectinitico Pilar e o Complexo Migmatitico Embu (Ha sui, 1975a e 1975b). A concepção parte da premissa de que o "front" de migmatização não tem significado estratigrāfico, representando a passagem para condições mais enérgicas de metamorfismo e feldspatização. Por outro lado, os Grupos Açungui e São Roque apresentam diferenças estruturais que, a despeito das semelhanças litológicas e do sincronismo,não permitem a reunião de ambos em uma só unidade estratigráfica (Hasui, 1975a; Hasui et a1., 1975).

0 Grupo São Roque restringe-se, por conseguinte, ao conjunto de blocos São Roque e o Grupo Açungui ao Conjunto Paranapiacaba (Hasui e Sadowski, 1976), na região a oeste da Capital.

As unidades anteriores a Ciclo Brasiliano constituíram um embasamento ainda mal conhecido na região entre São Paulo e Rio de Janeiro. As rochas do bloco Jundiai e do Conjunto Costeiro seriam, pelo menos em grande. 
parte, prē-brasilianas, presumivelmente pertencentes ao Grupo Paraỉba (Almeida et al., 1973). No domỉnio do Grupo Açungui, nūcleos prē-brasilianos esparsos têm sido reconhe cidos (Hasui e Sadowski, 1976; Melfi et al., 1976).

As datações radiométricas vêm dar apoio às considerações acima, uma vez que no dominio dos conjuntos São Roque e Paranapiacaba as idades pertencem ao intervalo do Ciclo Brasiliano (450-700 m.a.). Na extensão para o Vale do Paraíba, embora faltem estudos específicos que carac terizem a continuidade dos conjuntos acima, existem data ções também pertencentes ao Ciclo Brasiliano (Vandoros e 01iveira, 1969; Minioli, 1971; Wernick et a1., 1976). As rochas do Bloco Jundiaí e do Conjunto Costeiro são mais an tigas (Hasui e Hama, 1972; Wernick et al.,op.cit.).

Na folha de São José dos Campos são encontra das rochas referỉveis ao Grupo Açungui e rochas mais antigas. A distribuição dessas rochas é condicionada pelo padrão de blocos justapostos descrito em capitulo anterior.

Nos blocos Terra Boa, Monteiro Lobato, São José dos Campos e Serra do Jambeiro as rochas ectiniticas e migmatîticas pertencem ao Grupo Açungui. Evidências de evolução polifásica serão apresentadas adiante.

As rochas mais antigas têm seu dominio no bloco Bengala onde foram mapeados granulitos afetados por migmatização e retrometamorfismo que parecem relacionar-se ao Grupo Paraỉba. A inexistência de datações radiométricas na folha de São José dos Campos impede a confirmação de tal hipōtese.

No bloco Monteiro Lobato as rochas ectiniticas encontram-se no interior de grandes estruturas sinformais, passando gradualmente para migmatitos cada vez mais evoluídos em direção ao nūcleo das feições culminantes. 0 
bloco São José dos Campos exibe um padrão semelhante, com variações litológicas mais rāpidas, onde as exposições de ec tinitos não são mapeáveis na presente escala de trabalho.

Na região do Bairro do Morro Podre e em alguns pontos do Falhamento Transcorrente do Buquira foram en contrados "sizls" de diabásio onde o plagioclásio presente $\bar{e}$ a andesina.

$\mathrm{Na}$ região do Litoral Norte do Estado, Freitas (1976, p.103) agrupa estas rochas básicas, que ali ocorrem sob forma de diques, num ciclo magmático compreendido entre 104 e $130 \mathrm{~m} . \mathrm{a}$. , com base em datações fornecidas por Amaral et al (1966), Vandoros (1966), Melfi (1967) e Minioli et al (1971).

Os sedimentos que preenchem a Bacia de Taubaté são separados em termos de depósitos antigos e modernos. os depósitos antigos são englobados sob a denominação Grupo Taubaté (Mezzalira, 1962), subdividido em duas formações (Almeida, 1957): a basal é a Formação Tremembé, separada por discordância da Formação Superior. Esta última foi cognominada por Moraes Rego (1933b) de Formação São Paulo, numa extrapolação baseada na litologia e no pressuposto de que as bacias de São Paulo e Taubaté estivessem unidas no passado.

A evolução das duas bacias foi independente, embora em sincronismo, conforme demonstram Ab'Saber (1957b) e Hasui et al (1976), por critērios geomorfológicos e estru turais, respectivamente. Por conseguinte, o nome formação São Paulo não é adequado.

Em 1969, Ab'Saber, considerando uma discordān cia plano-paralela encontrada nos espigões entre os rios Ja guari e Paraíba do Sul, subdividiu a Formação Superior em duas outras formações: a Formação São José dos Campos e a 
Formação Parateī-do-Meio, juntando-as à Formação Tremembé, para compor o Grupo Paraíba do Sul (Ab'Saber, 1969 a).

Carneiro et al (1976) preferem manter a denominação Grupo Taubaté "por prioridade e para evitar confusão do nome Paraíba do sul com o da unidade pré- Cambria na (Ebert, 2957)". Considerando que a discordância mencionada por Ab'Saber não havia sido reconhecida nem em āreas prōximas (Titarelli, 1975), estes autores preferiram manter a Formação Superior indivisa, adotando o nome Formação Caçapava. A formação é bem exposta nos cortes ao longo da Via Dutra.

Os niveis de terraceamento e de sedimenta ção em vārzeas atuais desenvolveram-se após o assoreamento da Bacia, de tal modo que não são englobados na denominação Grupo Taubaté. São denominados genericamente de depós $\underline{i}$ tos quaternārios. 
CAPITULO VI

\section{MAGMATISMO}

A atividade ĩgnea estā representada na área

por:

1. Rochas básicas, metamorfizadas em anfibolitos e metabas $\underline{i}$ tos, em corpos restritos (Fig.3).

2. Rochas granitóides de natureza sintectōnica:

Estas rochas apresentam-se intimamente asso ciadas a migmatitos evoluídos no núcleo de estruturas culmi nantes e são principalmente granitos orientados, aos quais se subordinam tipos porfiroblásticos e sem orientação.

No maciço do Roncador, maior corpo granitóide da ārea, a natureza sintectōnica das rochas é denunciada pe la foliação, pela forma alongada do corpo e por uma feição de contatos parcialmente transicionais, conforme a classifi cação de Marmo (1971). A existência de contatos abruptos e de tipos litológicos porfiroblásticos de foliação incipiente ou até inexistente vem favorecer a idéia de que se trata de corpo sintectonico para-autóctone no conceito de Read (1957), possuindo contatos parcialmente intrusivos mas sem efeitos de metamorfismo de contato.

3. Pequenos "sizzs"de diabásio, na região do Bairro do Morro Podre, na região da Falha do Buquira (Foto 24) e da região da Fazenda São Sebastião.

$\vec{A}$ evolução do Ciclo Brasiliano estariam relacionadas as rochas metabásicas, afetadas por metamorfismo regional, e os corpos granitóides sintectonicos para-autóctones. Os "sizls" de rochas básicas estão vinculados à Reativação Wealdeniana da Plataforma Sul-Americana (Almeida 1967). 


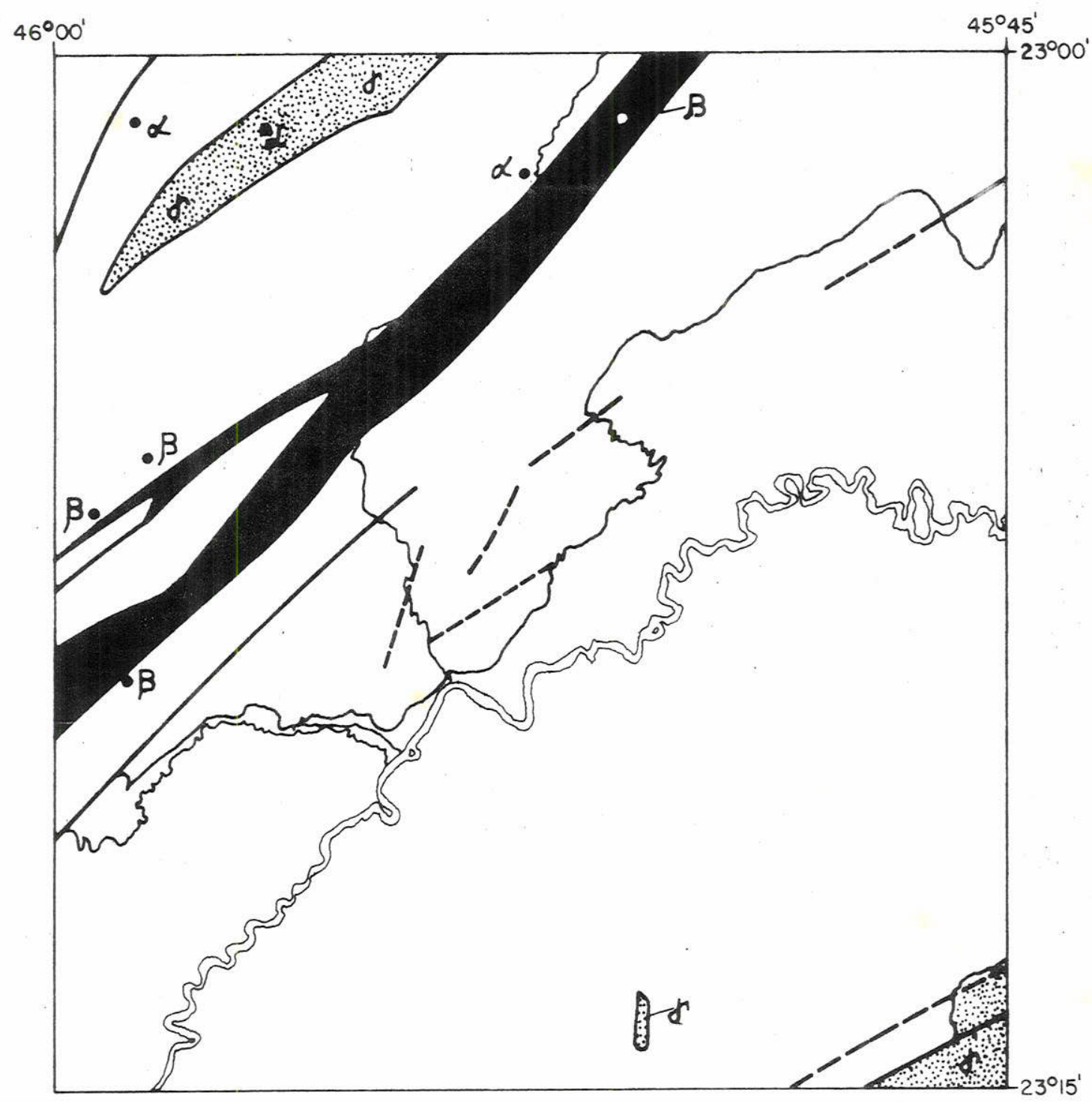

- $\beta$ Sills de diabásio

Rochas granitóides sintectonicas em corpos para-autoctones

- $\alpha$ Rochas básicas, metamorfisadas

Fig.3-LOCALIZAÇÃO DOS AFLORAMENTOS DE CORPOS MAGMÁTICOS MAPEADOSNA QUADRICULA DE SÃO JOSÉ DOS CAMPOS 
CAPITULO VII

METAMORF ISMO

Nos blocos Monteiro Lobato e Terra Boa o meta morfismo regional deu-se no fácies xisto verde a anfibolito, originando, no bloco Monteiro Lobato, desde filitos até mig matitos cujo paleossoma tem associações minerais compati veis ao fácies anfibolito.

No bloco são José dos Campos as assembiéias minerais são referíveis ao fácies anfibolito, enquanto que no bloco Bengala desenvolveram-se paragēneses correspondentes ao fácies anfibolito e granulito. Paragēneses de desequilibrio foram constatadas nas associações de biotita-clorita, hornblenda-biotita, piroxēnio uralizitado e plagioclá sio saussuritizado.

0 metamorfismo dinâmico que se desenvolveu após o início do metamorfismo regional está associado aos falhamentos transcorrentes que separam os blocos tectōnicos.

Considerando o aumento progressivo da intensi dade do processo, as brechas tectônicas representam um está dio inicial da sequência, em que se desenvolvem flexões de planos de clivagem e de lamelas de geminação, fraturas nos cristais, granulação em seus bordos e fragmentação dos cris tais de micas. Uma etapa seguinte é a representada pelos protomilonitos, onde a fragmentação dos cristais de biotita e quartzo é acentuada, a textura em moldura é conspícua ao redor dos fenoclastos de feldspato e hornblenda e a foliação da rocha está claramente perceptĩvel.

Nos milonitos, a massa moida representa uma parcela considerável da rocha, imersos na qual os fenoclas- 
tos tendem a diminuir de tamanho e a desaparecerem. A folia ção da rocha está bem desenvolvida e, por estiramento ou fricção de cristais, surgem lineações nos planos de folia ção, paralelas entre si e à direção de movimento. Nos estāgios finais, os ultramilonitos constituem-se em rochas finas, de granulação submicroscópica e foliação pronunciada. os acessórios ainda relativamente intactos nos milonitos, titanita, apatita e epídoto, jā passam a sofrer moagem. Recristalização de quartzo em grãos e cordões paralelos aos planos de foliação é efeito de temperaturas elevadas existentes nos últimos estágios do processo dinâmico.

A ocorrēncia de porfiroblastos poiquiloblásti cos de moscovita é generalizada por toda a área, afetando inclusive os blastomilonitos. Esta blastese foi já reconhecida mais a Oeste por Coutinho (1972) e Rideg (1974), parecendo tratar-se de um fenómeno regional. Os porfiroblastos não apresentam orientação preferencial, talvez traduzindo cristalização sob condições estáticas. 
O intervalo de tempo que separa as ūitimas ma nifestações do Ciclo Brasiliano dos fenōmenos relacionados à Reativação Wealdeniana da Plataforma pode ser tomado como re feréncia para se separar, com fins de abordagem, as estruturas presentes na região em duas categorias distintas no tempo: as estruturas próprias do embasamento e as estruturas re lacionadas à Reativação da Plataforma.

\section{Estruturas do Embasamento}

A estratificação reliquiar é observāvel nos filitos do bloco Monteiro Lobato atravēs da alternāncia de lâminas ou camadas milimétricas a centimétricas de constitui ção metapelîtica com outras, de composição mais quartzosa. Nas rochas migmatíticas, camadas de quartzitos e quartzitos calcossilicáticos, em geral interrompidas, denunciam a estra tificação reliquiar. Algumas bandas de composição, cores ou granulometria diferentes entre si podem ainda servir para ca racterizā-1a.

A xistosidade, no conceito de orientação planar de minerais placóides ou prismáticos e de agregados de grãos (Billings, 1954), é aqui entendida como correspondente às foliações plano-axial de Whitten (1966), à clivagem de fluxo e à clivagem ardosiana de outros autores (Hobbs et al, $1976)$.

Em rochas filiticas do bloco Monteiro Lobato e em alguns āpices isolados de dobras de quartzitos da re gião da zona de falhamento do Buquira, encontramos xistosida 
de plano-axial atravessando a estratificação reliquiar no ápice das dobras. Nas demais unidades rochosas, esta feição é mais rara, já que as dobras são configuradas pela estrati ficação, pela xistosidade e pelo bandamento metamōrfico, pa ralelos entre si. o bandamento metamōrfico é aqui entendido como a intercalação de bandas de neossoma concordantes com a xistosidade nos migmatitos.

Esta feição de dobras deformando a xistosidade levou Hasui (1973) a considerar uma primeira fase de dobramento gerando dobras isoclinais recumbentes com xistosidade plano-axial e transposição intensa. Em uma segunda fase, a superposição criaria dobras de planos axiais subverti cais.

O dobramento da segunda fase gerou dobras de dimensões centimétricas a métricas, visiveis nos afloramentos. São dobras cilindricas, de planos axiais subverticais, com eixos subhorizontais. Regionalmente, os perfis destas dobras são fechados a isoclinais, caracterizando uma geometria da classe 3 de Ramsay (1967), onde os āpices são espes sados e os flancos, adelgaçados. Os quartzitos (Foto 27) e migmatitos estromatíticos (Foto 28) ilustram bem esta situa ção. Localmente, as dobras apresentam perfis abertos, desenhando ondulações mais suaves. Tal é a situação encontrada nos migmatitos estromatíticos da parte NE da Serra do Palmi tal.

Boudinage de camadas quartziticas e rochas calcossilicatadas é comum no interior de migmatitos de paleossoma xistoso. Apices isolados de dobras destas rochas de natureza mais competente são mais raros. São ápices intrafoliais gerados na primeira fase do dobramento e isolados por um fenōmeno de transposição.

Em àmbito regional, dobras maiores foram reconhecidas pelas gradações entre termos ectiniticos e migma 


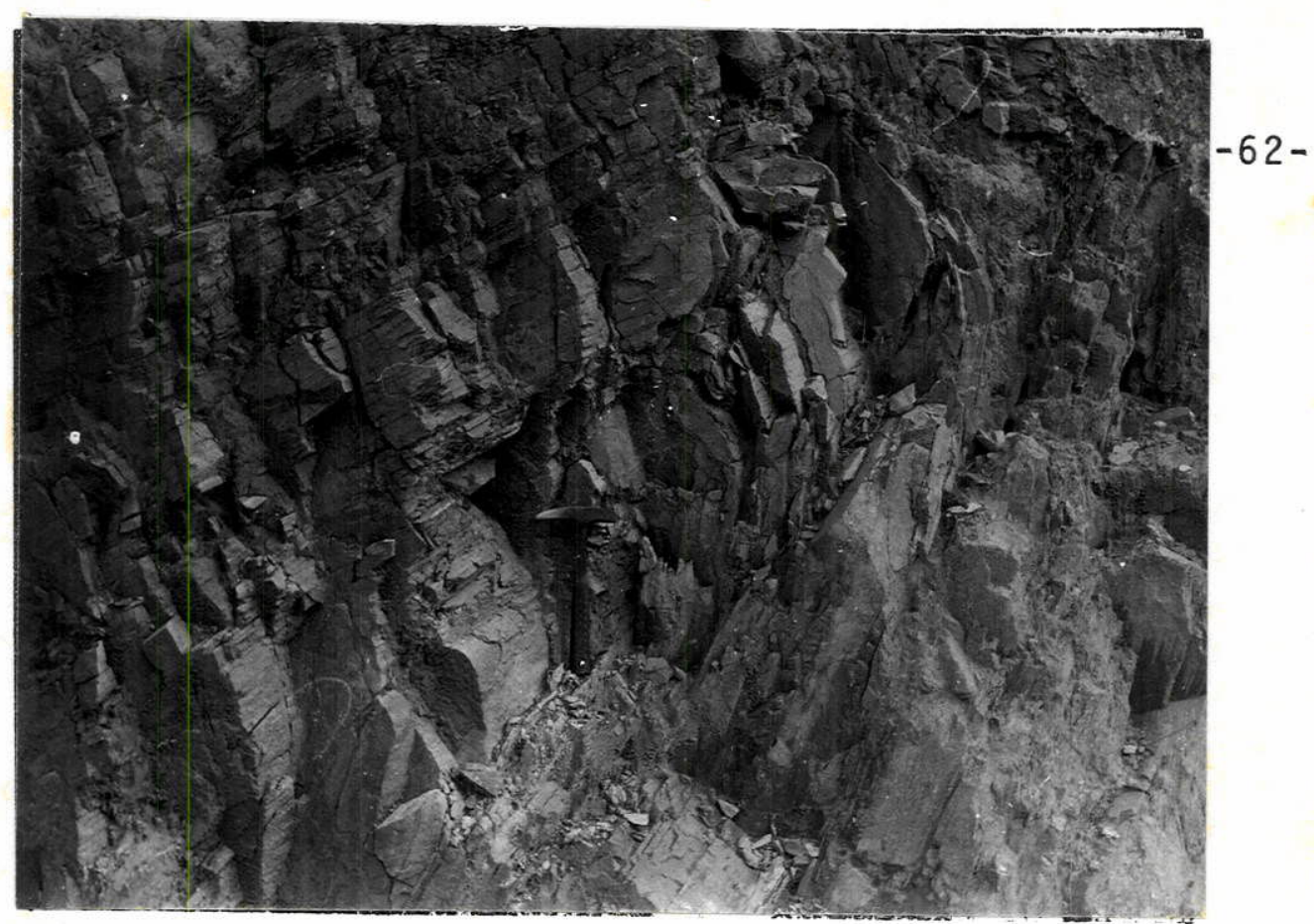

FOTO 27 - Dobra fechada anisópaca em quartzito do Bloco Ben gala exibindo espessamento de äpice. Notar a exis tência de intenso fraturamento transversal ao eixo da dobra. Bairro Ponte do Costinha, a $1 \mathrm{~km} \mathrm{da}$ SP-50. $(040468 / \mathrm{SJ})$.

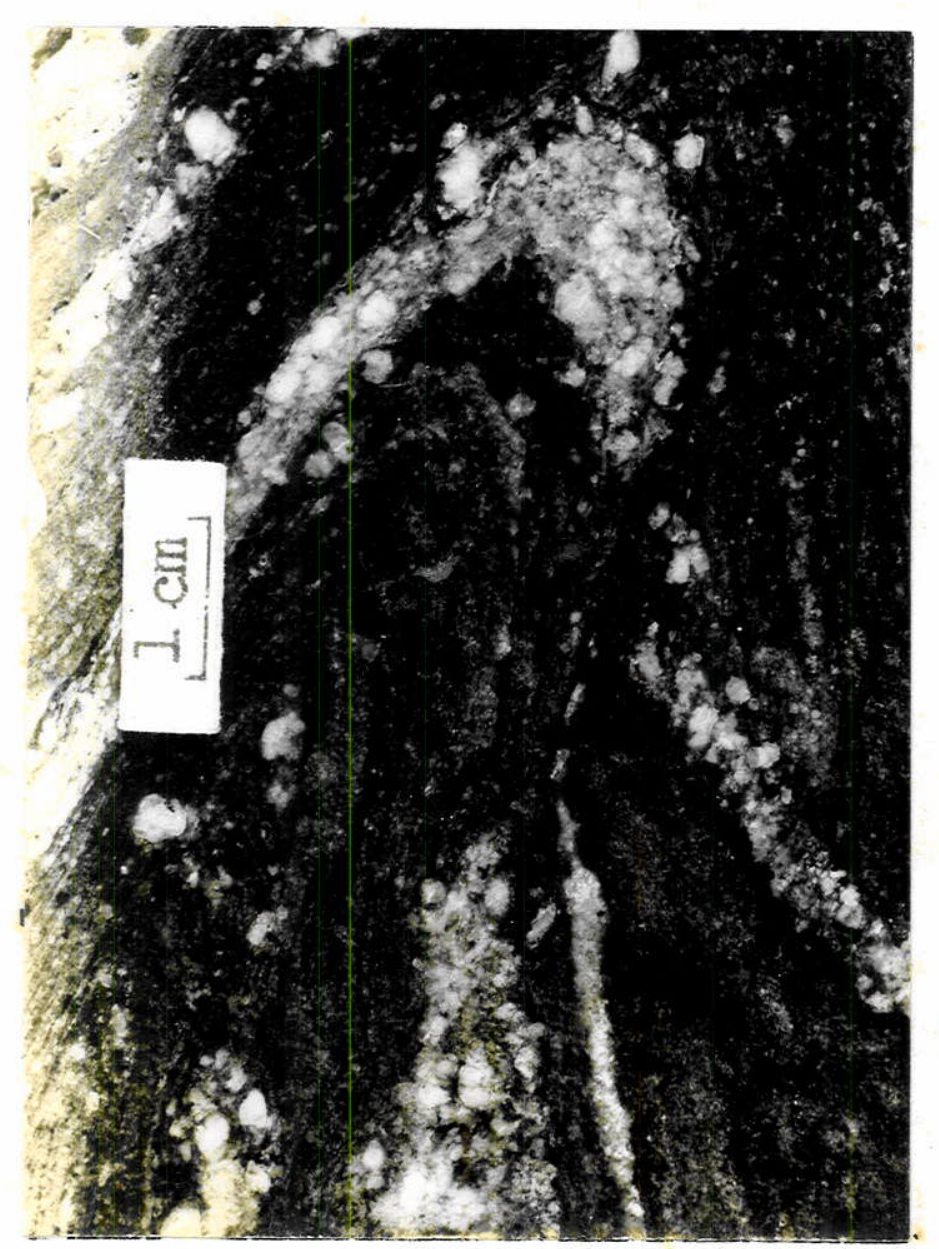

FOTO 28 - Pormenor da foto 17. Dobra cerrada anisōpaca em migma tito homogêneo do blo co Bengala. A banda de neossoma dobrada (centro da foto) sofreu estricção e boudinage. Bairro dos Freitas, a sul do Cör rego do Bengala. 
$-63-$

tîticos. As feições antiformais apresentam um aumento da in tensidade de migmatização das bordas para o nūcleo, com transições desde rochas estromatíticas heterogêneas para migmatitos bandados homogéneos até atingir os migmatitos em brechiticos ou de estruturas mais complexas no nūcleo. Nas faixas sinformais, a situação é inversa, com os migmatitos dando lugar, em direção ao nūcleo das grandes estruturas, a rochas ectniticas.

No bloco Monteiro Lobato tal situação é mais clara, por encontrarmos trés zonas sinformais separadas por duas, de estrutura antiformal. De sul para norte, temos 0 sinclinōilo do Morro Podre, a antiforma da Ägua Soca, o sin clinōrio do Rio Turvo, a antiforma do Roncador, e a sinforma do Rio do Peixe. Nesta última, não se observam os merguIhos para o núcleo em ambos os lados da estrutura sinclinorial, talvez devido ao falhamento Monteiro Lobato, que trun ca seu flanco noroeste.

No Sinclinōrio do Rio Turvo, dobras reversas fechadas nos estromatitos dos cortes da estrada Agua Soca Rio do Peixe (048525/SJ) têm planos axiais inclinados e sub paralelos aos mergulhos do bandamento metamórfico que apontam para o centro da estrutura.

No bloco São José dos Campos, a principal fei ção antiformal reconhecida situa-se na região da Serra do Palmital. Dobras de plano axial inclinado para fora da estrutura foram observadas em alguns pontos dos flancos.

Estruturas de crenulação e transposição são visiveis nos ectinitos e migmatitos. Os planos de cisalha mento que se desenvolvem ondulam e deformam a xistosidade, chegando a transpō-la inteiramente, como è o caso de um sinclinal em xistos, na região do Bairro do Juarez (989519/ SJ). Neste afloramento, em ambos os flancos da dobra, os mergulhos da xistosidade são convergentes e, aproximando-se 
$-64-$

do nūcleo da estrutura, surgem planos de crenulação chegando a desenvolver uma nova "xistosidade" no ápice do sinclinal.

Esta evolução não é tão completa nas demais āreas, onde se constata a presença de microlittons milimétrị cos separados por planos de cisalhamento nos quais a xistosidade é deformada em ondulações sigmoidais, indicativas do sentido da movimentação.

No tocante ãs estruturas disruptivas, as faThas transcorrentes são as feições mais expressivas da ārea estudada e o seu arranjo configura os blocos tectōnicos des critos anteriormente. A intensidade do processo de moagem é variāvel no interior das zonas de cataclase, gerando muitas vezes uma foliação conspícua, em planos que mergulham gera 1 mente para SE ou então são verticais.

Lineações nos planos de foliação, originadas pelo processo dinâmico, são paralelas à direção de movimentação e inclinam-se em geral para NE. Sua origem está ligada ao deslocamento relativo de alguns grãos minerais mais resistentes criando estrias nas superfícies formadas por ma terial moído.

No falhamento transcorrente do Buquira, a foliação mergulha sistematicamente para SE, alcançando valores de atē 450 de mergulho. (v.Foto 25). As lineações podem atingir até 20 ọ de inclinação para NE (Foto 29).

0 rejeito destas falhas e o sentido de movimentação não puderam ser observados no campo. Na falha do Buquira, contudo, um argumento favorável a um possível deslocamento dextral parece-nos ser a disposição dos protomilonitos ocelares muito semelhantes em cor, granulação, composição mineralógica e estrutura, aos migmatitos embrechîti cos que sustentam a barragem do rio Jaguari. Os embrechitos 
foram mapeados atē a região do bairro do Caeté e os protomilonitos ocelares são constatados para nordeste, atē os afloramentos do bairro Ponte do Costinha, na luz da falha. Ainda não se dispõe de dados acerca da existência e locali zação de rochas embrechïticas equivalentes no bloco norte da falha do Buquira.

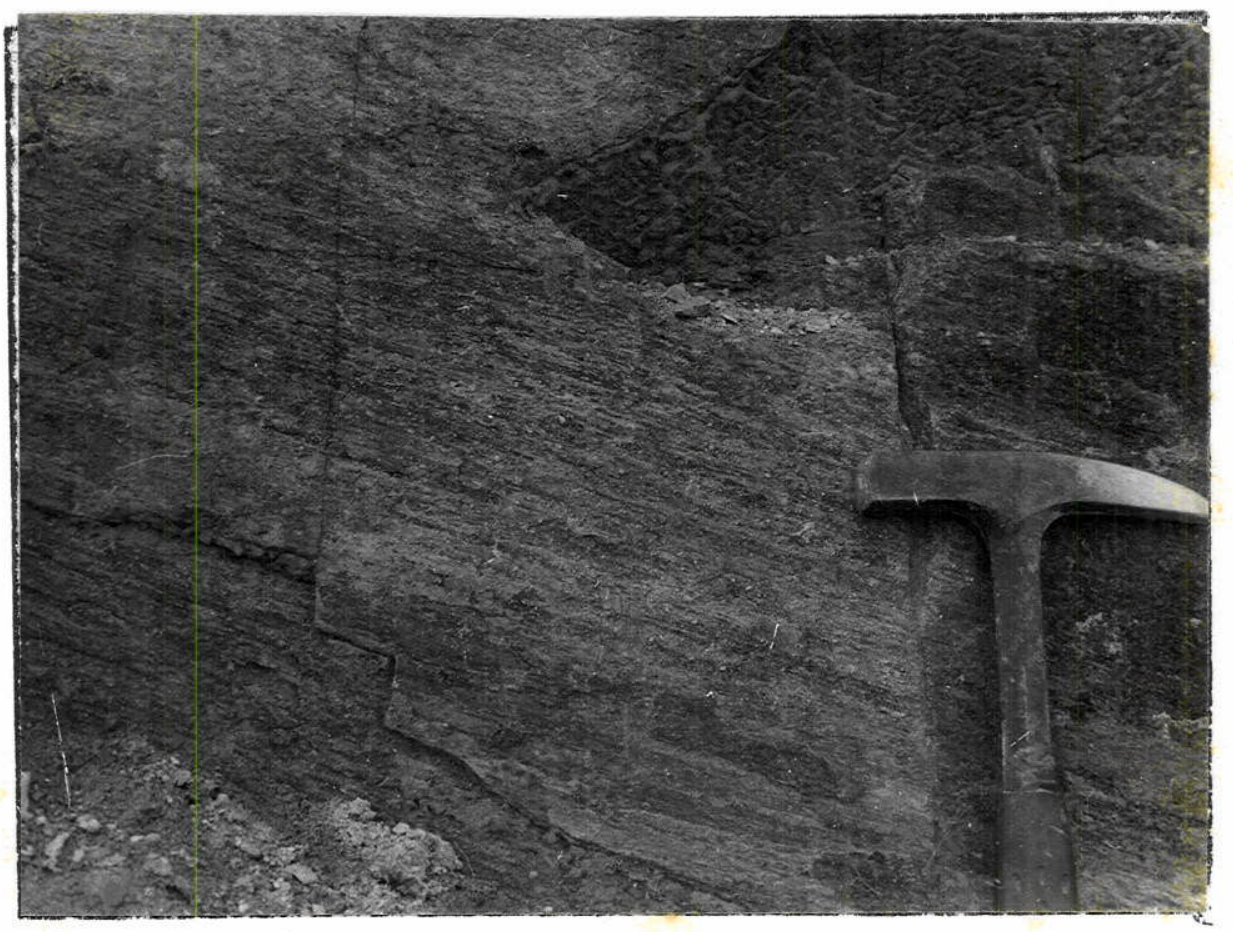

FOTO 29 - Lineações na zona de falhamento do Buquira,contidas em plano de foliação subvertical dos milo nitos. O conjunto é cortado por pequenas juntas. Bairro da Agua Soca, proximidades da ponte so bre o Rio Buquira. (076497/SJ). 
0 Mapa de Lineamentos Fotogeológicos (em ane xo) foi construỉdo segundo descrevemos na página 4 , cons 1 derando exclusivamente aqueles lineamentos relacionados ao traçado de cursos d'água. O conceito de lineamento é contudo, mais amplo, entendendo-se todas as feições retilineas da superfície da Terra que aparecem nas fotos aéreas como linhas distinguĩveis por sua tonalidade (Ricci e Petri, 1965). As causas destes lineamentos podem ou não estar rela cionados aos caracteres estruturais do terreno.

Dois padrões gerais de lineamentos destacamse na folha estudada: um deles desenvolve-se sobre os sedimentos da Bacia de Taubatē e o outro, sobre as rochas do em basamento metamōrfico. Neste segundo caso,as relações dos lineamentos para com as estruturas presentes foram -objeto de anālise estrutural em domīnios homogêneos especificamente definidos com base na regularidade de orientação das 1 inhas e nas condições de afloramento das rochas.

As āreas homogēneas foram escolnidas sobre os principais blocos tectónicos e falhas transcorrentes da ārea, conforme indicado na Fig.4, de modo a permitir a determinação dos padrões de orientação preferencial das juntas e da foliação das rochas e um exame adequado das relações entre os sistemas de juntas e outras estruturas presen tes.

Os diagramas obtidos são do tipo $\pi$, em estereograma de SCHMIDT-LAMBERT, representando as projeções das normais aos planos no hemisfērio inferior da esfera de refe rência (Figuras de 5 a 10 ).

Os blocos unitārios à direita dos diagramas foram construīdos segundo o método descrito por: Ruhland (1973), com base nos sistemas preferenciais de juntas, à exceção da ārea 1, onde consideramos também a foliação. As representações foram feitas em diagrama de SCHMIDT-LAMBERT, 


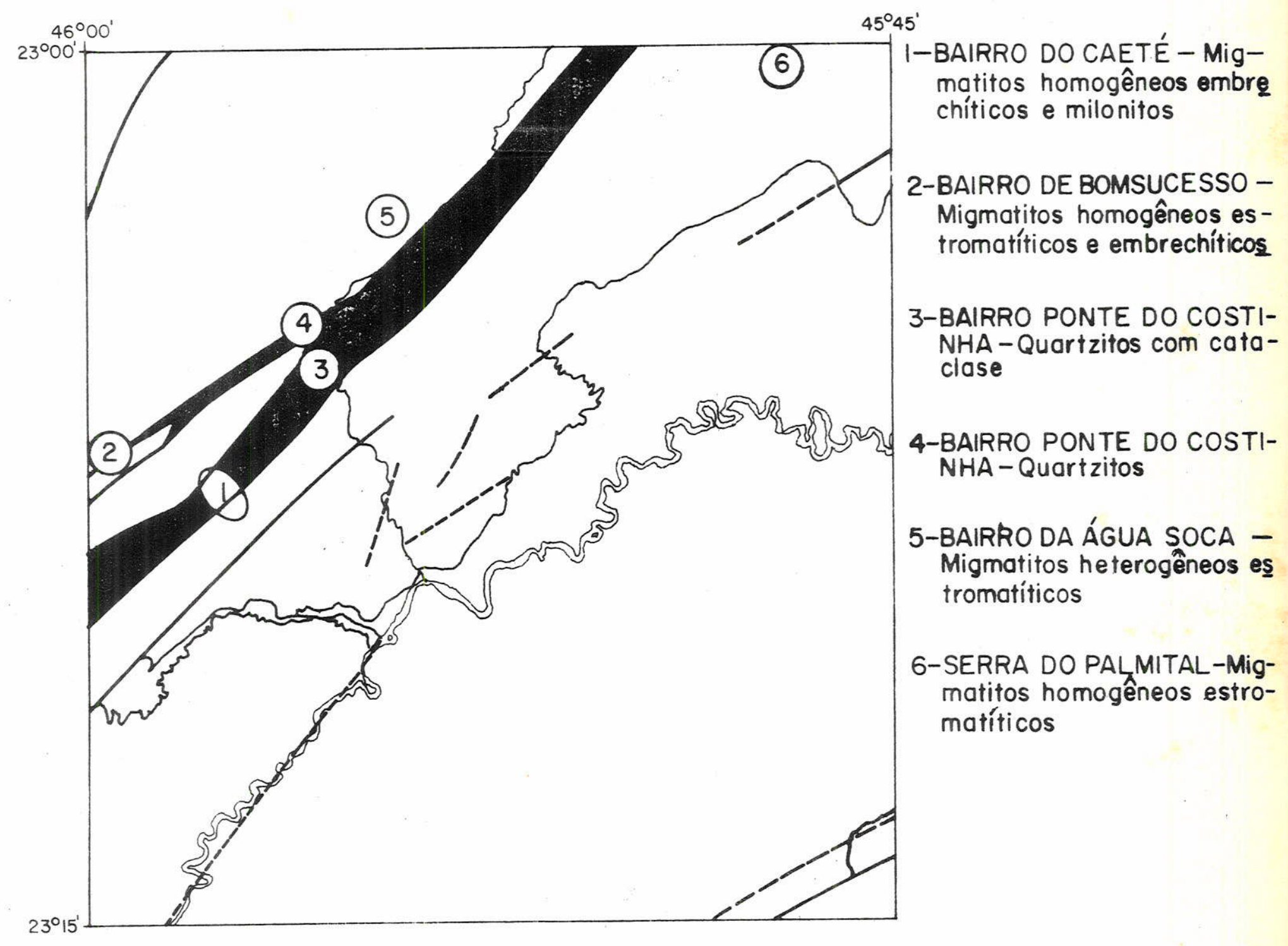

Fig.4-DOMÍNIOS HOMOGÊNEOS ESCOLHIDOS PARA ANÁLISE DO PADRÃO GEOMÉTRICO DE JUNTAS. 
hemisfërio inferior de referēncia, de tal modo que a forma dos blocos é determinada por:

1. interseções entre os sistemas de planos.

2. relação entre os espaçamentos médios de plaños de um mesmo sistema.

Para facilidade de compreensão dos blocos $\underline{u}$ nitārios, deve-se lembrar que a projeção estereográfica em hemisfério inferior admite, por definição, o observador si tuado acima do diagrama, no polo norte da esfera. Os blo cos unitários, por sua vez, são construīdos com arestas e faces paralelas, rebatidas para o plano horizontal, o que implica necessariamente num observador situado acima do diagrama, no infinito. Esta dualidade de sistemas de proje ção deve ser considerada para observação dos blocos.

Pela observação dos diagramas $\pi$ das figuras 5 a 10 constatamos que nas āreas de 1 a 5 há dois ou trēs sistemas predominantes subverticais e um ou dois subhorizontais. Na ärea 6 hä maior dispersão de polos porēm o padrão ainda é mantido. A foliação è subvertical em todas as äreas, exceto na ārea 6 , como se verifica no exame dos dados da tabela 1 , onde são fornecidos tambēm os valores médios obtidos para os sistemas preferenciais de juntas.

$\mathrm{Na}$ ärea 1 , o fraturamento das rochas ē mais intenso nos milonitos da Zona de Falhamento do Buquira, mas a orientação das fraturas é constante ao se passar para os migmatitos do Bloco São José dos Campos (Fig.5). Dos dois sistemas subtransversais à foliação, um é vertical e outro subhorizontal. Um terceiro conjunto é obliqquo.

$\mathrm{Na}$ ärea 2, o espaçamento entre as juntas é maior (Foto 30) e muda a orientação dos sistemas preferen ciais (Fig.6), que englobam dois conjuntos obliquos à folia ção e um subhorizontal subtransversal. O sistema subtrans- 


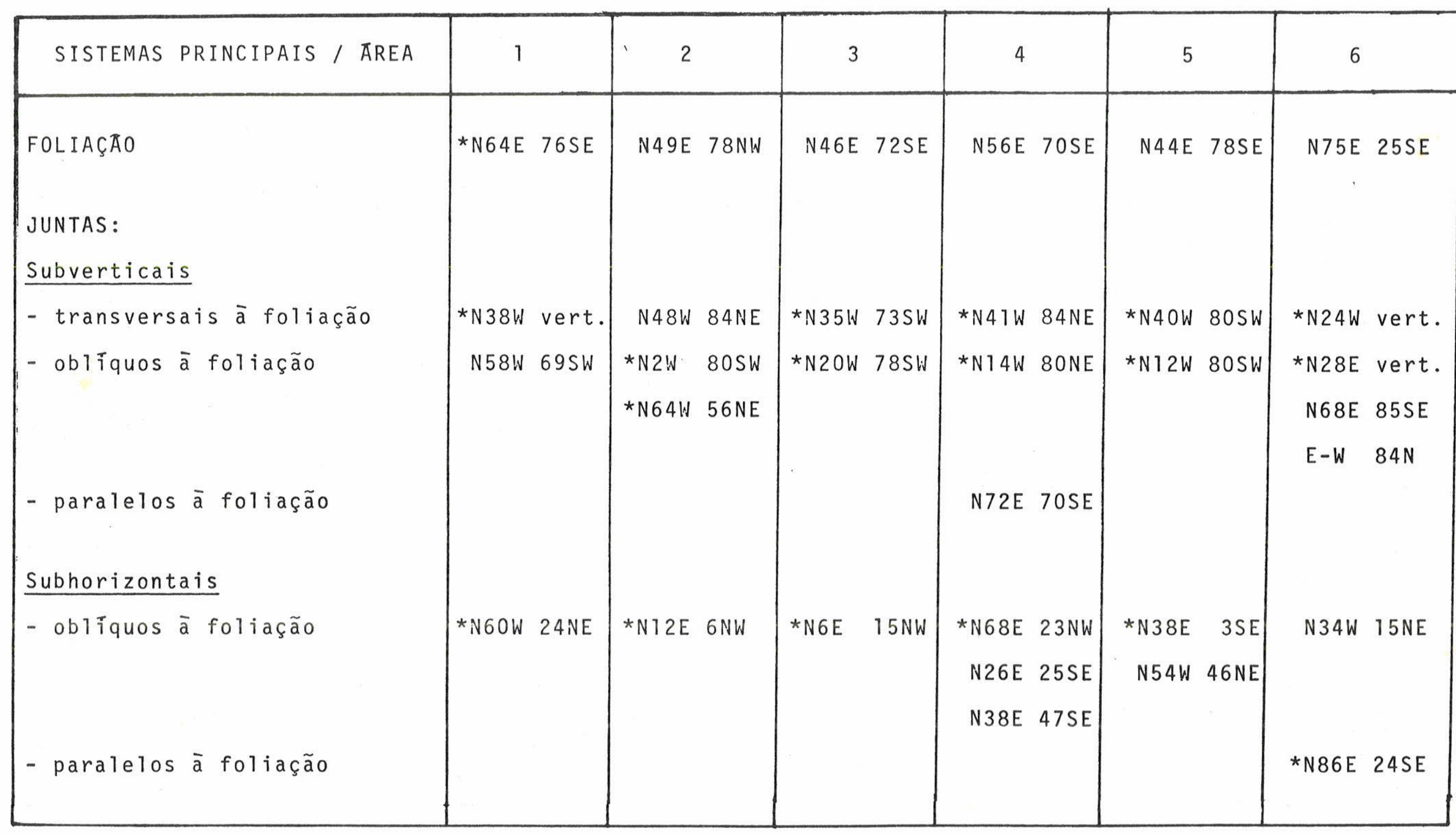

* sistemas considerados para a construção dos blocos unitarios

TABELA 1 - ATITUdes dOMINANTES dAS JUNTAS E SUAS RELAÇZES PARA COM A FOLIAÇAO 


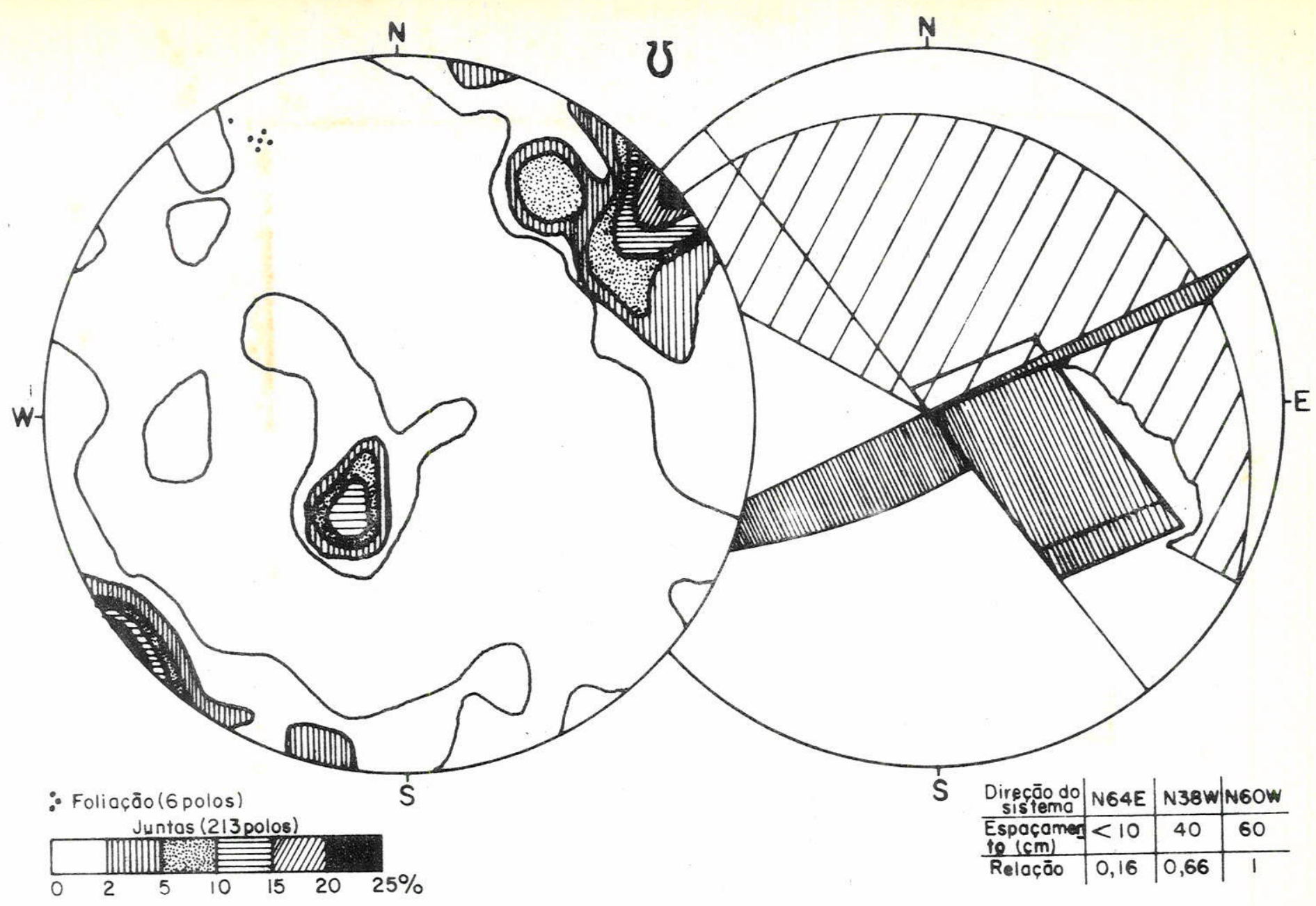

FIG. 5 -DIAGRAMA $\pi$ DE JUNTAS E FOLIAÇĀO NA ÁREAI. O BLOCO UNITÁRIO À DIREITA RESULTA DOS SISTEMAS PRINCIPAIS DE JUNTAS E FOLIAÇÃO. DIAGRAMA DE SCHMIDT-LAMBERT, HEMISFÉRIO INFERIOR DA ESFERA DE REFERÊNCIA.

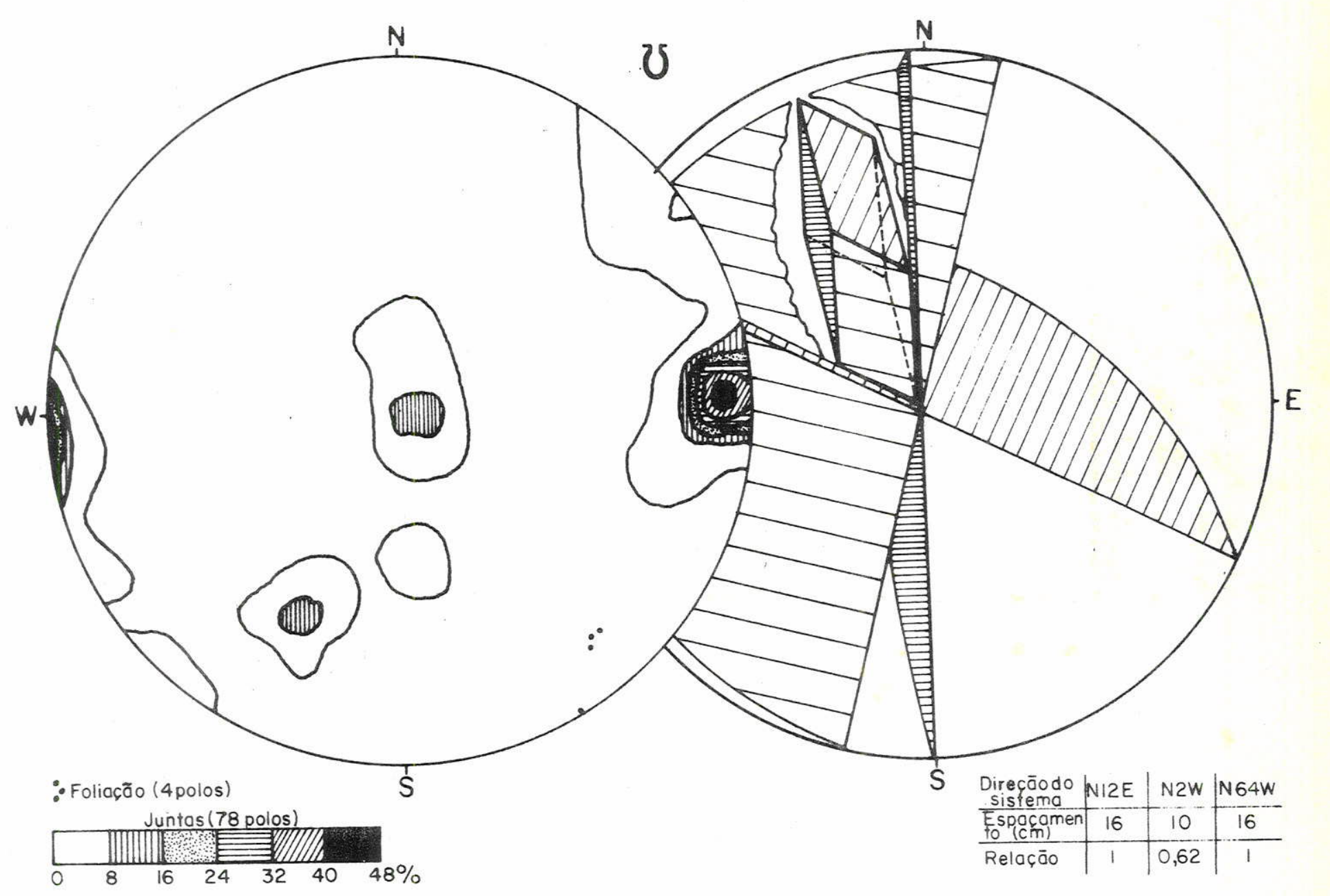

FIG. 6 - DIAGRAMA $\pi$ DE JUNTAS E FOLIAÇĀO NA ÁREA2. O BLOCO UNITÁRIO À DIREITA RESULTA DOS SISTEMAS PRINCIPAIS DE JUNTAS. DIAGRAMA DE SCHMIDT - LAMBERT, HEMISFÉRIO INFERIOR DA ESFERA DE REFERÊNCIA. 


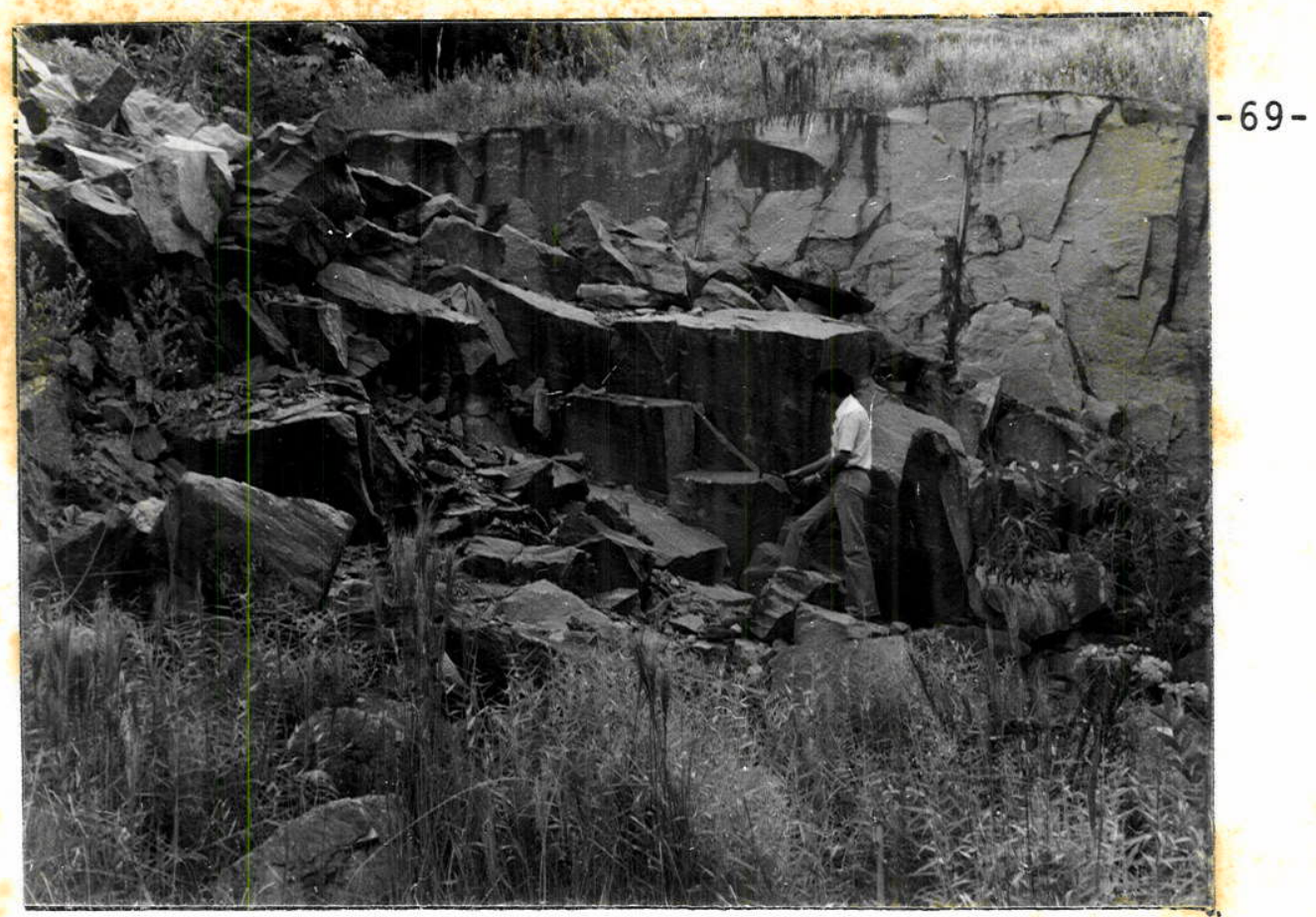

FOTO 30 - Pedreira no estromatito homogêneo do Bloco Mon teiro Lobato. Os planos do bandamento metamórfico são paralelos ao plano da foto e são cortados por juntas subhorizontais e subverticais quase perpendiculares entre si. Bairro do Bonsucesso, margem direita do R.Turvo ( $979448 / \mathrm{sJ})$

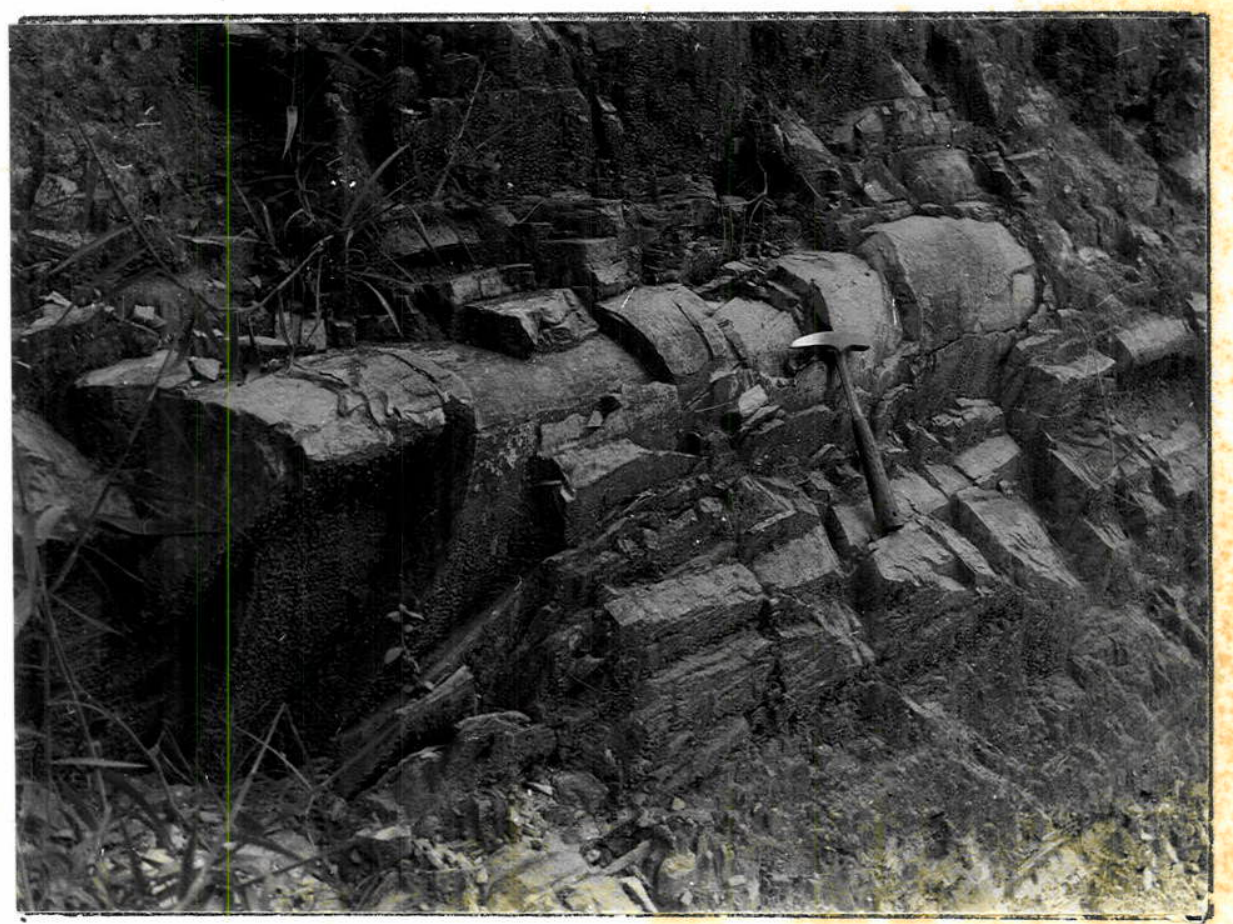

FOTO 31 - Sistemas de juntas cortando uma antiforma em quart zitos. A incipiente xistosidade estä em posição plano-axial. A dobra da foto 28 situa-se nesté mes mo corte de estrada. Bairro Ponte do Costinha, a $1 \mathrm{~km} \mathrm{da} \mathrm{SP-50} \mathrm{(040468/SJ).}$ 
versal subvertical teve frequência menor que $8 \%$, de sorte que não se destaca no diagrama.

A ärea 3 é situada no interior da zona de falhamento transcorrente, e as medidas foram feitas em rochas quartzîticas cataclasadas. O fraturamento é bastante intenso e a orientação das fraturas obedece a um padrão mais complexo que nas demais äreas, com maior dispersão dos polos (Fig.7). Os sistemas preferenciais incluem: um subvertical e subtransversal à foliação, um sistema oblīquo subvertical e outro obliquo subhorizontal. Os dois ūitimos acham-se associados a outros de menor expressão, res ponsāveis pela dispersão de polos constatada.

0 afloramento estudado na ārea 4 compõe -se de uma sequência de äpices de dobra anisōpaca em quartzitos, que apresentam notáveis sistemas de juntas (Foto 31 ). Dos trēs grupos subverticais, um é transversal à foliação, outro é obliquo, e o terceiro é subparalelo (Fig.8). Os sistemas subhorizontais variam em orientação.

Na área 5, hā dois sistemas oblīquos à foliação, dos quais um é subvertical; hā um sistema horizontal; e um quarto sistema, subvertical e subtransversal à foliação.(Fig.9).

A ärea 6 conta com um sistema vertical obliqquo à foliação, um vertical transversal e um sistema subhorizontal paralelo à mesma. Também verifica-se uma certa dispersão de polos (Fig.10).

Em todas as áreas, portanto, constatamos até três sistemas de juntas subverticais, um dos quais ē subtransversal à foliação. A geometria dos sistemas sugere que este seria de partição e os outros dois conjuntos, obli quos à foliação, de cisalhamento. Sadowski (1974, p.88) re laciona ainda um sistema subhorizontal a juntas de alívio e mostra um sistema paralelo aos planos axiais do ūitimo 


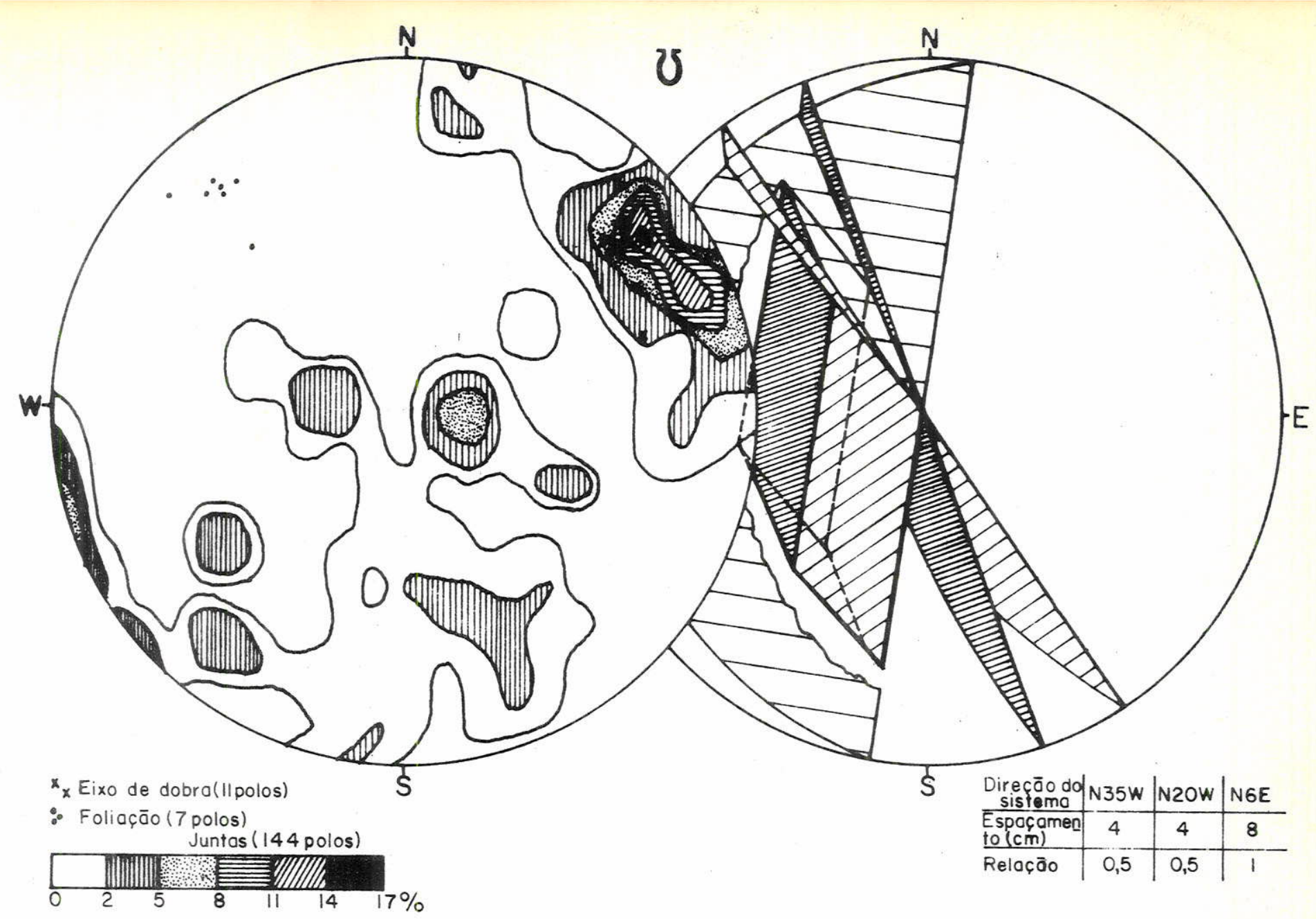

FIG.7 -DIAGRAMA $T$ DE JUNTAS E FOLIAÇĀO NA ÁREA 3.0 BLOCO UNITÁRIO Á DIREITA RESULTA DOS SISTEMAS PRINCIPAIS DE JUNTAS. DIAGRAMA DE SCHMIDT - LAMBERT, HEMISFÉRIO INFERIOR DA ESFERA DE REFERENCIA.

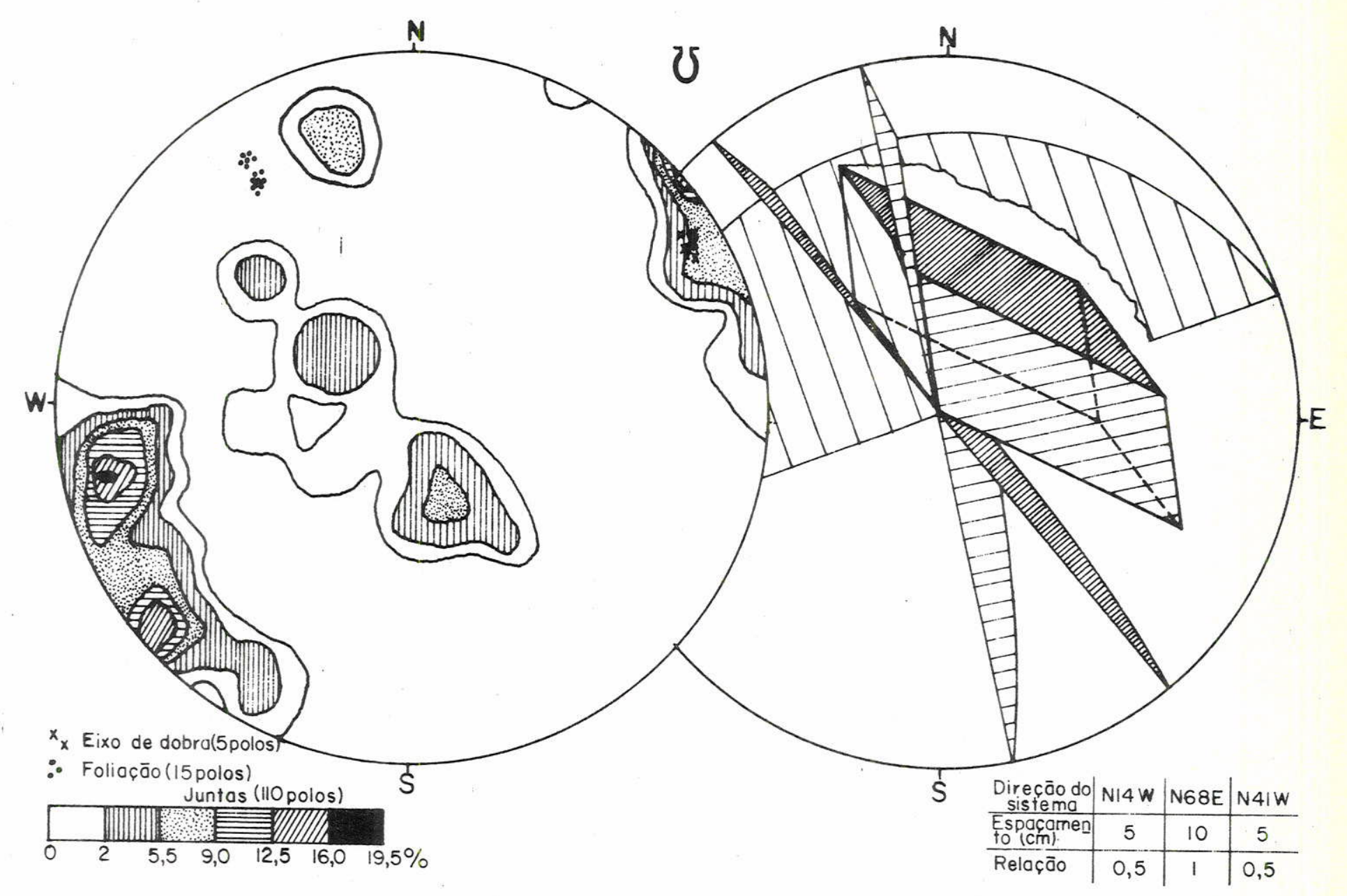

FIG.8 -DIAGRAMA $\pi$ DE JUNTAS E FOLIAÇĀO NA ÁREA4. O BLOCO UNITÁRIO À DIREITA RESULTA DOS SISTEMAS PRINCIPAIS DE JUNTAS. DIAGRAMA DE SCHMIDT - LAMBERT, HEMISFÉRIO INFERI OR DA ESFERA DE REFERÊNCIA. 


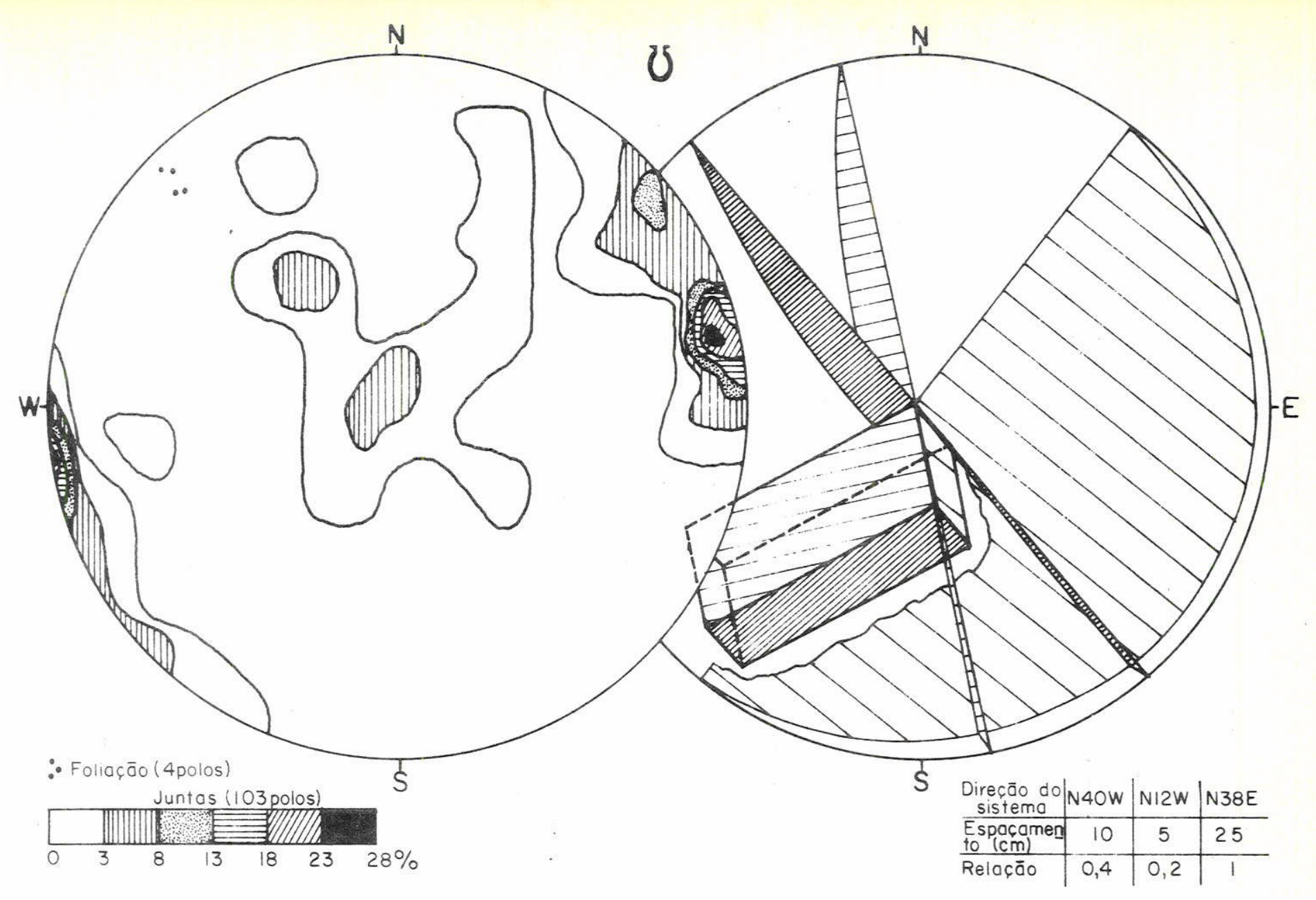

FIG. 9 -DIAGRAMA $\pi$ DE JUNTAS E FOLIAÇĀO NA ÁREA 5. O BLOCO UNITÁRIO À DIREITA RESULTA DOS SISTEMAS PRINCIPAIS DE JUNTAS. DIAGRAMA DE SCHMIDT - LAMBERT, HEMISFÉRIO INFERIOR DA ESFERA DE REFERÊNCIA.

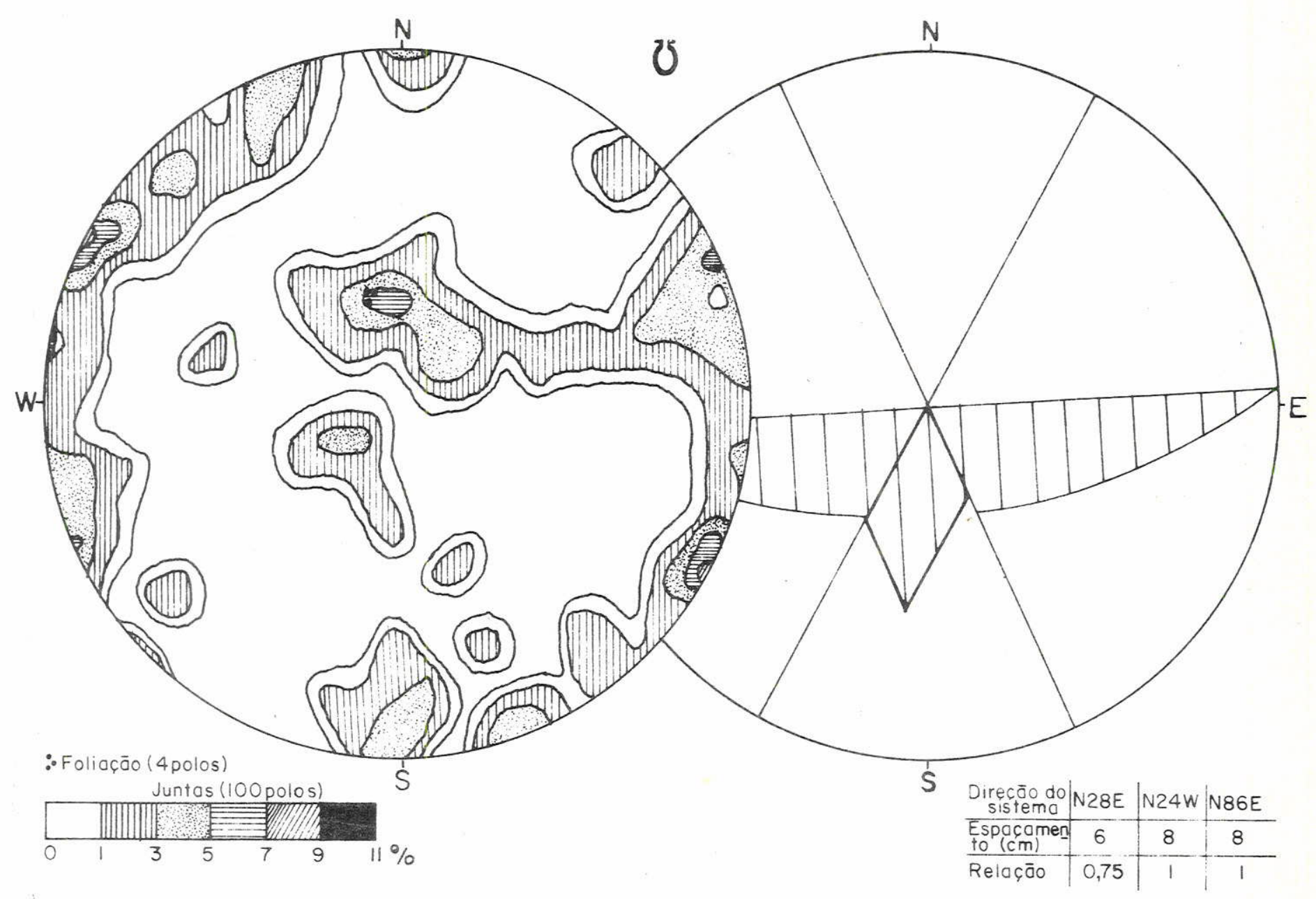

FIG. IO -DIAGRAMA $\pi$ DE JUNTAS E FOLIACĀO NA ÁREA 6. O BLOCO UNITÁRIO Á DIREITA RESULTA DOS SISTEMAS PRINCIPAIS DE JUNTAS. DIAGRAMA DE SCHMIDT - LAMBERT, HEMISFÉRIO INFERIOR DA ESFERA DE REFERENCIA. 
dobramento ou da transposição. Atribui tal distribuição sim ples de juntas em uma área polideformada a um comportamento rígido dos maciços apenas nas fases finais de deformação.

$\mathrm{Na}$ extrapolação destes resultados para o Mapa de Lineamentos Fotogeológicos vemos que os sistemas de juntas subverticais e a foliação têm grande importância no traçado da rede de drenagem.os longos coletores têm seu cur so encaixado paralelamente às direções da foliação e dos eixos do dobramento, enquanto seus numerosos tributários re fletem a orientação dos sistemas de juntas, particularmente o sistema de partição. Os pequenos cursos d'água que, sulcando as vertentes menores procuram aqueles tributários, acompanham novamente as direções de fraqueza dadas pela foliação e por "sets" menores de juntas e pequenas falhas 1on gitudinais.

A comparação entre os blocos unitários revela que, à exceção da ārea 1, onde se considerou a foliação, todos têm uma forma que tende à prismätica de base sublosan gular, com variações na posição espacial e no tamanho, consequência das diferentes orientações e espaçamentos das jun tas. Esta constância na forma dos blocos, seja em āreas a fastadas dos falhamentos transcorrentes ou em áreas no seu interior, é indīcio de que as juntas não se formaram contem poraneamente aos fenômenos de milonitização.

Considerando as rochas regionais e as rochas afetadas pela cataclase, dentro de uma mesma ārea homogênea como na ārea 1 , ou em āreas homogēneas próximas, como nas āreas 3 e 4 , verificamos inexistirem fortes contrastes no padrão de orientação.

Estes fatos vêm dar apoio à idēia de que as juntas foram as ūitimas estruturas brasilianas a se formar na ārea, cortando indistintamente todas as unidades litologicas presentes, inclusive os produtos de milonitização. 


\section{Estruturas Relacionadas à Reativação da Plataforma}

Os movimentos gerados pela Reativação Wealde niana (Almeida, 1967) condicionaram o aparecimento de intrú sões bāsicas, falhas de gravidade, reativações de falhas antigas e consequentes deslocamentos de blocos. 0 graben do Paraíba do Sul, que contēm a Bacia de Taubaté, desenvolveu se sob estas condições tectônicas.

As intrusões bāsicas não foram ainda datadas por meios radiométricos, mas parece-nos plausivel a sua ligação aos episódios iniciais de movimentação e reativação de falhas antigas. Formam estruturas concordantes, "sizzs" tabulares e estreitos da ordem de decímetros a poucos metros. O diaclasamento é paralelo às paredes nas bordas e transversal a elas no núcleo. A ocorréncia das manifesta ções é nas proximidades da Falha do Rio Jaguari e no interior da Zona de Falha do Buquira.

A reativação de falhas antigas foi verifica da pela existência, nos planos de foliação dos milonitos, de estrias de atrito acompanhando o mergulho dos planos e seccionado as lineações subhorizontais anteriores. Isto caracteriza uma segunda fase de movimentação, normal ou inversa, afetando as falhas do Bom Retiro e do Buquira (Fig.11).

As falhas geradas durante o Estágio de Reati vação não são do mesmo tipo. Correspondem a vārias superfīcies e planos de cisalhamento prōximos, subparalelos e anas tomosados, compondo zonas de disjunção a que chamaremos, pá ra simplificar, de falhas.

São as falhas do Parateĩ, Palmital, São Josē e do Rio Comprido, descritas por Carneiro et al (1976).

0 mapa da figura 11 abrange uma ārea da ba- 
Fig.ll-A BACIA DE TAUBATÉ (ENTRE JACAREI E CACAPAVA)

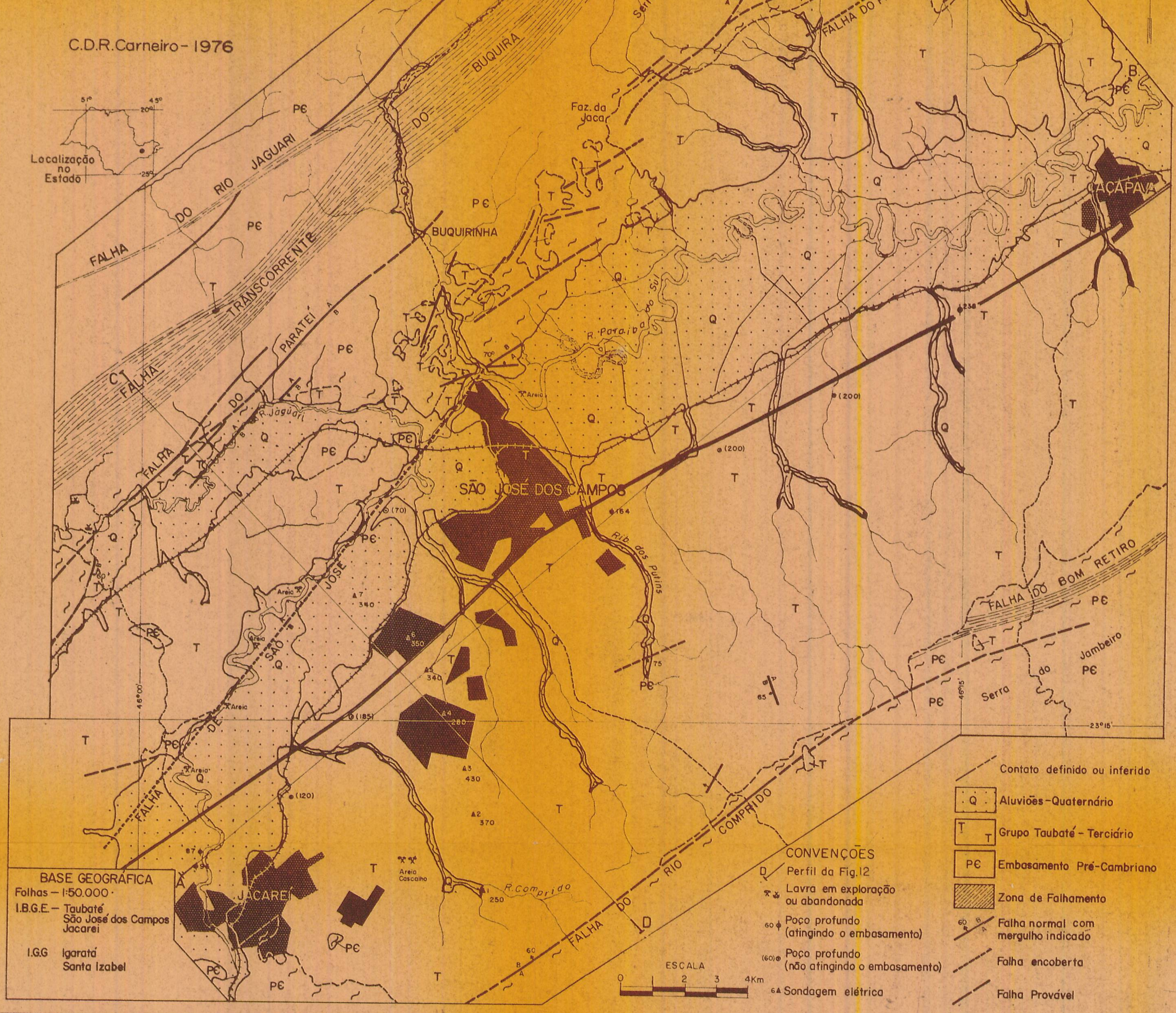


cia maior que a da folha de São Josē dos Campos, de modo a permitir um exame mais adequado da estrutura da Bacia. Da sua comparação com o esquema de compartimentação tectônica apresentado, emerge que a bacia se instalou em um substrato constituído pelo bloco são José dos Campos e por uma parte marginal do bloco Serra do Jambeiro.

Os falhamentos transcorrentes, embora possam ter controlado parcialmente a movimentação de blocos, parecem exercer influência secundāria na delimitação da Ba cia. As falhas do Parateí e do Palmital limitam os sedimen tos a norte, enquanto as do Rio Comprido e do Bom Retiro os limitam a sul. A falha de São José caracteriza uma segmentação na unidade sedimentar, de vez que isola e condiciona a evolução de dois compartimentos distintos do graben: os Compartimentos Parateí e Jacareí (Carneiro et al., 1976 ).

Nos perfis da figura 12 constatamos lque 0 Compartimento Parateí tem seu embasamento adernado para NW, com maiores espessuras provavelmente para este lado, en quanto que a SE o embasamento se expõe em janelas junto à falha de São José.

o Compartimento Jacareī é segmentado por uma falha subsuperficial, que se estende por Jacareí e Caçapava, em dois subblocos, suavemente adernados para NW. As espessuras de sedimentos são maiores neste sentido.

Os dados de sondagens profundas assinalam uma subcompartimentação longitudinal da depressão, com zonas mais profundas situadas entre Jacareí e São Josē dos Campos e entre esta cidade e Caçapava (Fig.12). De fato,ex posições do embasamento existem no interior da bacia, como o afloramento no Rio Putins e o do Bairro do Menino Jesus, em Caçapava. 


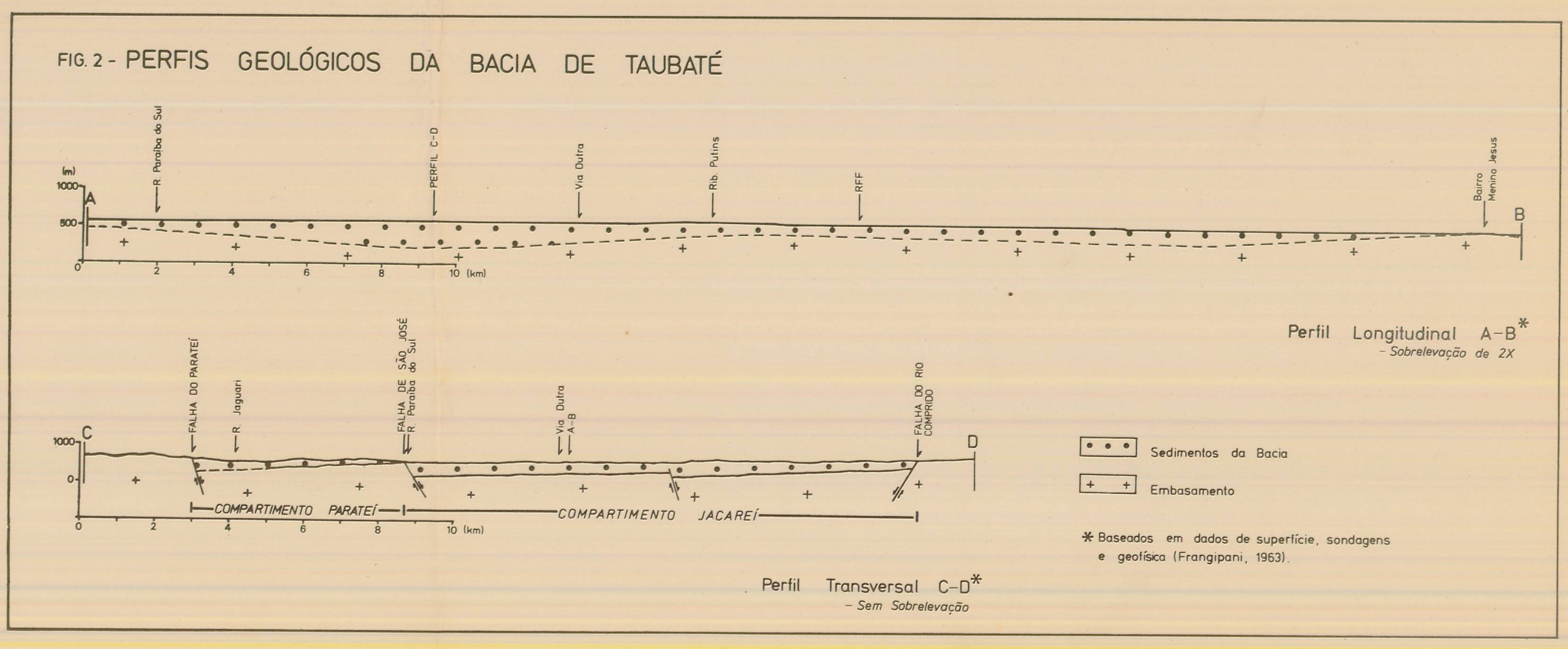


Falhas nos sedimentos são verificadas em vārios locais, como na região dos Bairros Pernambucano e Alto da Ponte (Foto 32), em São José dos Campos. As falhas são geralmente normais, às vezes com antitéticas ou conjugadas associadas. Podem ser localmente inversas, talvez representando falhas conjugadas associadas a outras, de caráter nor mal.

Falhas cortando pequenas manchas de sedimen tos aparecem na rodovia SP-50 e na Zona de Falha do Buquira. Naquela, o corte de estrada expõe um trato sedimentar adernado para NW que tem, na sua extremidade setentrional, uma falha normal N30E subvertical (Foto 32). Na região da Fazenda Santa Luzia, sobre a Falha do Buquira, uma mancha de sedimentos terciārios é profundamente cortada por planos de falha subverticais e muito prōximos. 


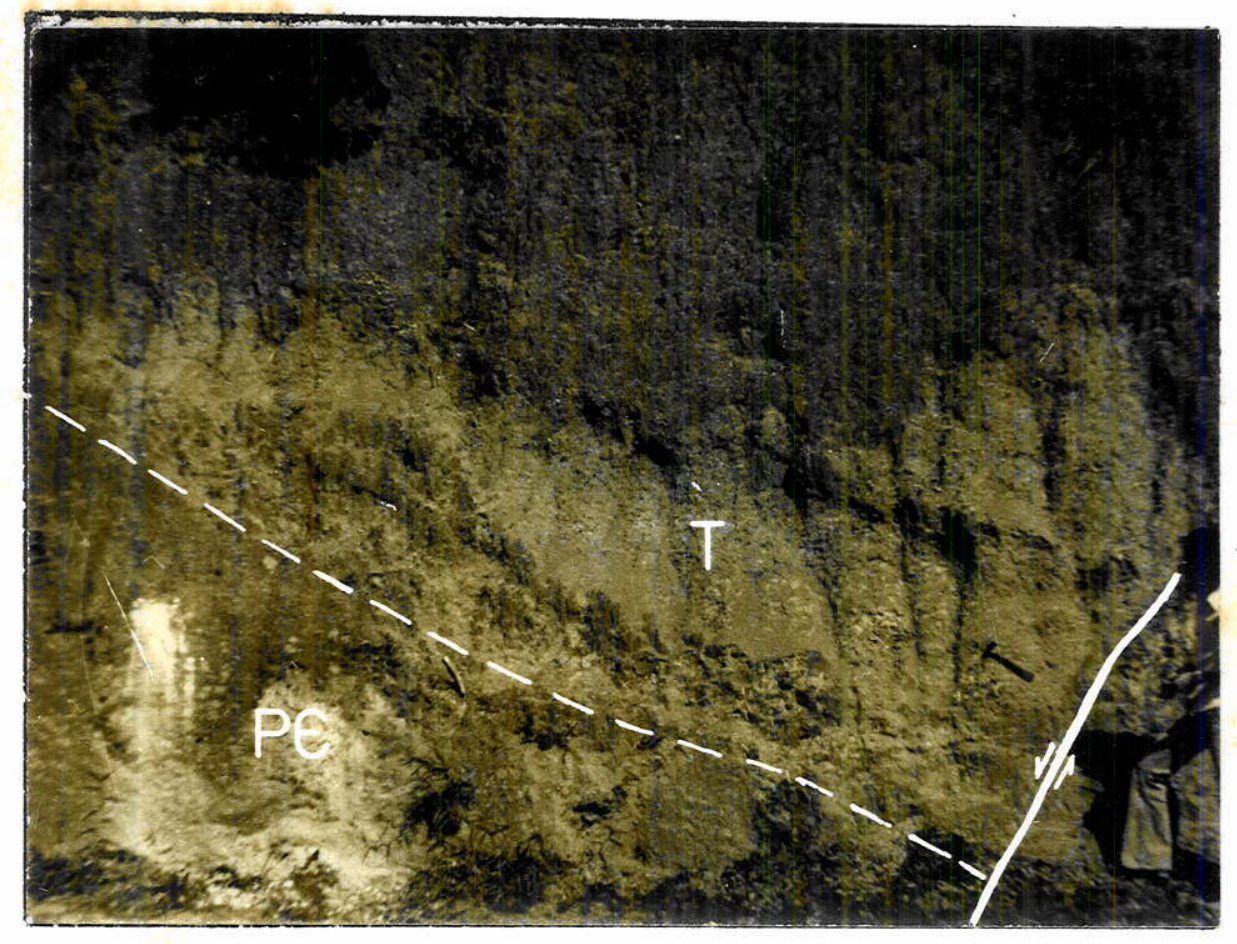

FOTO 32 - Camadas de sedimentos da Bacia adernadas para NW e embutidos por falha nos migmatitos do Bloco São José dos Campos. Rodovia SP-50, a $2,5 \mathrm{~km} d a$ Ponte sobre o Rio Paraíba do Sul (071410/SJ). 
CAPITULO IX

GEOMORFOLOGIA

No conjunto de fatores que determinam as for mas atuais do relềvo, é relevante a participação das litolo gias e das estruturas condicionando o modelado topográfico. 0 propósito destas breves notas é apresentar alguns dados sobre as formas predominantes do relevo na quadricula e a influência do substrato rochoso em sua escultura.

Situada inteiramente na Provīncia Geomórfica do Planalto Atlāntico (Almeida, 1964), a folha estudada encontra-se no domīnio das Zonas do Médio Vale do Paraíba e da Serra da Mantiqueira definidas por aquele autor. A primeira zona é desmembrada na subzona dos Morros Cristalinos e na subzona da Bacia de Taubaté, enquanto a segunda zona acha-se representada tão somente pela sua subzona 0cidental. A figura 13 delineia os limites entre estas zonas e subzonas, com base na descrição fornecida por Almeida (op.cit.), e em nossas observações.

A descrição destas zonas geomorfológicas encontra-se, detalhada, na obra de Almeida (1964). Destacamos aqui as observações de interesse para a quadrícula estudada, englobando os novos dados que coletamos na presente pesquisa.

1. Zona do Médio Vale do Paraíba

Ocupa cerca de $58 \%$ da folha estudada, e é re presentada pelas subzonas dos Morros Cristalinos e da Bacia de Taubaté. 
Fig. 13 -ESBOÇO DAS ZONAS FISIOGRÁFICAS NA ÁREA ESTUDADA

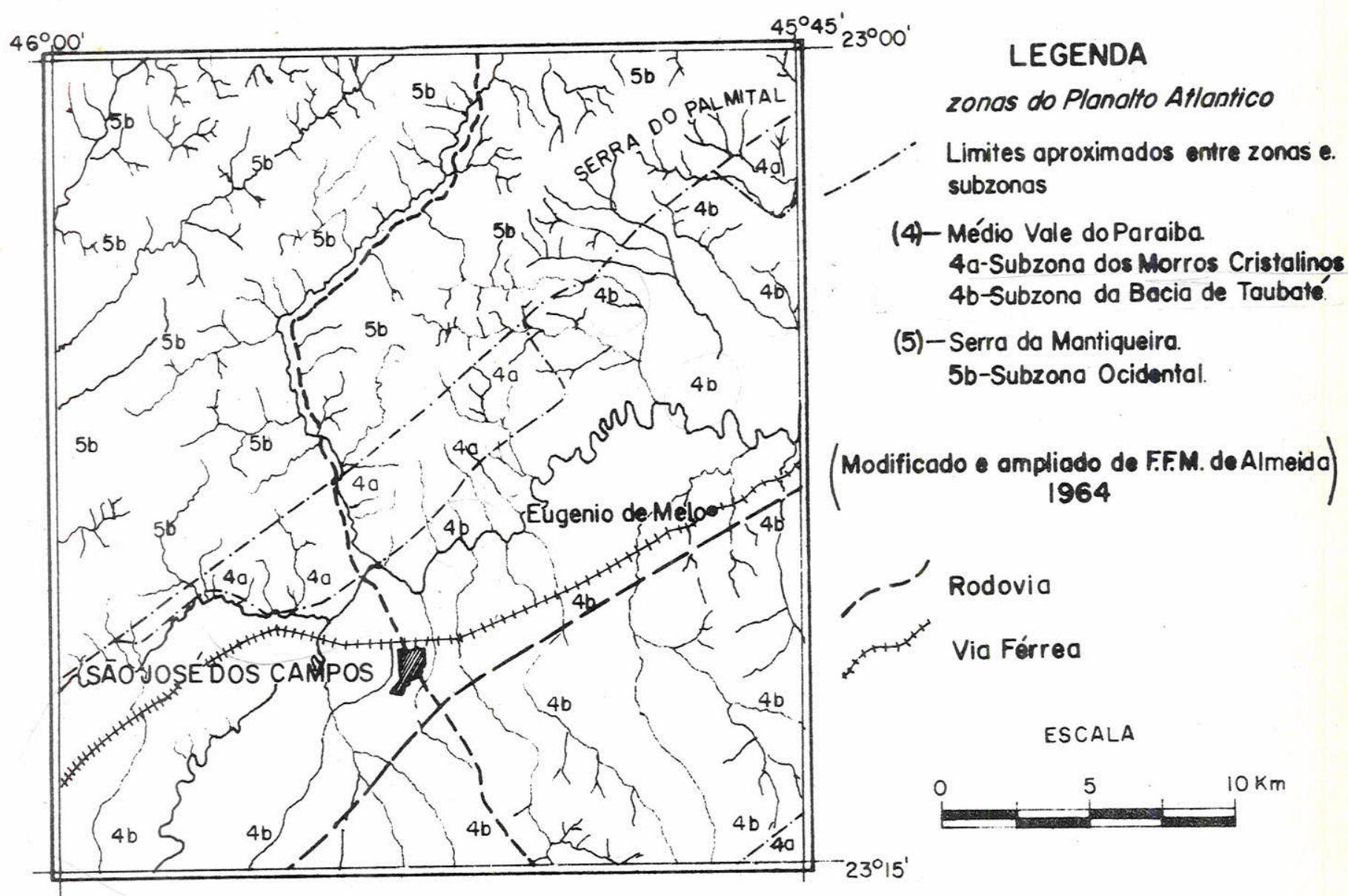


Esta subzona, no sentido adotado originalmen te, corresponde às paisagens de "mar de morros", profundamente esculpidas pela drenagem, que se instalou sob o controle das estruturas e da litologia.

Ao procurar os rios Jaguari, Buquira e Para ba, os coletores d'água principais desenvolvem curvos traça dos na maior parte de seus percursos, contrastando com o padrão retilíneo e paralelo com que se estendem seus tributários menores, refletindo particularmente o sistema de jun tas subtransversais à foliação.

Os morros são de modesta altura, com desni veis em geral menores que $200 \mathrm{~m}$ sobre o fundo dos vales. Man chas irregulares de sedimentos terciārios no tôpo ou nas en costas destas elevações são dispersas pela região a norte do Rio Paraíba (vide Mapa Geológico). As formas topogrāficas resultantes possuem um perfil suavizado, de tôpo levemente achatado onde se instalam, por vezes, pequenas depres sões circulares. Este tipo de feição é mais comum nas chapa das da subzona da Bacia de Taubaté.

\section{B. SUBZONA DA BACIA DE TAUBATE}

A faixa sedimentar apresenta, na sua porção central, relevo de baixas e extensas chapadas, às quais se associam, nas partes marginais, amplas colinas de perfis pouco inclinadas e suave convexidade.

A chapada de São José dos Campos, que Almeida (1964) aponta ser a mais extensa da Bacia, é caracteriza da por Medeiros e Ab'Saber (1969) como "uma espécie de tabu leiro de planalto, embutido na grande depressão tectônica regional". E atravessada por rios e córregos que buscam o 
Paraíba a NW, orientação em que o prōprio tabuleiro exibe um suave pendor, atribuĩvel à inclinação das camadas que 0 sustentam Almeida (op.cit.) indica cotas de $600 \mathrm{~m}$ em São José dos Campos, que atingem $695 \mathrm{~m}$ rumo a SE. Na carta topo gräfica estudada, cotas de $585 \mathrm{~m}$ e $710 \mathrm{~m}$ são estabelecidas para pontos situados respectivamente nas porções NW e SE da chapada.

Os rios e cōrregos que cortam a chapada formam calhas aluviais longas e achatadas, em desniveis que em geral não excedem $100 \mathrm{~m}$ do topo dos morros. Os perfis são maduros e hā uma tendência ao alargamento das cabeceiras por erosão remontante, que vai desfazendo as formas tabulares em colinas muito recortadas. Nestas porções as vertentes das chapadas são profundamente festonadas, com frequentes vestīgios de antigas boçorocas.

Na borda SE da Bacia, Ab'Saber (1956) assina la a existência de uma depressão periférica, observada na estrada de São José dos Campos a Paraibuna.

A porção sedimentar, no compartimento Parateî, no prolongamento que da várzea do Rio Paraỉba avança rumo à Serra do Palmital e em zonas mais restritas junto aos limites SE da Bacia, caracteriza-se por uma paisagem de amplas colinas de perfis suavizados que muitas vezes exibem topo convexo e vertentes suavemente cóncavas, herdadas de antigas boçorocas. Localmente, a constituição repetitiva das camadas chega a emprestar ao relevo o aspecto de disfar çados degraus que se delineiam em traços aproximadamente ho rizontais nas encostas.

As vārzeas atuais são amplas e sua largura a tinge atē $6,1 \mathrm{~km}$ na altura da Faz. Monte Alegre, excedendo de 4 vezes a largura de sua faixa de meandros. A continuida de das vārzeas maiores é apenas quebrada na região do Bair-ro Santana, em São José dos Campos, onde a largura da faixa 
aluvionar não supera $500 \mathrm{~m}$.

Niveis de terraços em testemunhos isolados são apontados por Ab'Saber (1969a) dos quais os baixos ter raços encontram-se em cotas de 3 a $8 \mathrm{~m}$ acima de nível da planỉcie de inundação.

2. Zona da Serra da Mantiqueira

A. SUBZONA OCIDENTAL

De acordo com Almeida (1964), esta subzona corresponde, na zona da Serra da Mantiqueira, ao "fronte $e$ rodido do bloco de falha "s incluindo "grande área cujo re levo resulta da profunda escultura do planalto sul-mineiro, não só pelos rios da bacia do Ṗaraíba émo da do Tietê".

A importāncia da erosão diferencial no modelado do relevo é cuidadosamente descrita por aquele autor, que atribui às serras do Palmital e do Buquira o cará ter de elevações testemunhas, "que o recuo erosivo das grandes escarpas vem abandonando".

Ăquela descrição cabe ressaltar mais uma vez o importante papel assumido pelas feições estruturais como juntas, falhas e planos de foliação, descritos em capítulo anterior e que conduzem ao aparecimento de um pa drão de drenagem paralelo e subretangular.

Ao papel das estruturas soma-se o efeito condicionante das litologias, posto que as zonas mais baixas são sustentadas por rochas heterogêneas, xistosas, ao passo que as elevações são suportadas por rochas mais homo gêneas. As maiores altitudes na folha estudada se encontram nesta subzona, sobre as serras do Palmital e do Ronca 
dor e na região do Morro do Jacu. No alto da primeira, uma espēcie de platô desfeito em morros situa-se acima dos 900 metros de altitude, enquanto nas duas ūltimas hā vestígios de erosão do nūcleo das antiformas, criando depressões em forma de anfiteatros, com vertentes bastante recortadas pe la drenagem, num arranjo subdendritico.

A drenagem encaixou-se de modo notāvel,alar gando seus vales onde a resistência oferecida era menor, e formando depósitos aluvionares relacionados a nīveis de ba se locais. Estes depōsitos são autēnticos patamares no per curso dos riachos e cōrregos, logo sucedidos de cachoeiras a juzante (Fotos 33 e 34 ). Na região da Serra do Palmital, 5 destes patamares foram reconhecidos, sucessivamente a co tas abaixo de $900,740,700,660$ e $580 \mathrm{~m}$. Investigações geomorfológicas futuras poderão vir a explicar sua gēnese.

Na região da Falha do Buquira, merece ser assinalada a distribuição não uniforme dos terraços aluvio nares. Longos soalhos aluviais cortam a faixa cataclástica, e são deixados por tributārios da margem esquerda do Rio Buquira. Em virtude da baixa resistência oferecida pelos milonitos, a inexistência de tais assoalhos na margem di reita estaria explicada, mas não se pode descartar a hipótese de uma reativação moderna do falhamento, elevando o bloco a NW e possibilitando a intensificação da erosão. De fato, na região do bairro da Āgua Soca todos os tributários que de NW procuram o Buquira desenvolvem cachoeiras nos ūitimos $200 \mathrm{~m}$ de seus percursos. 


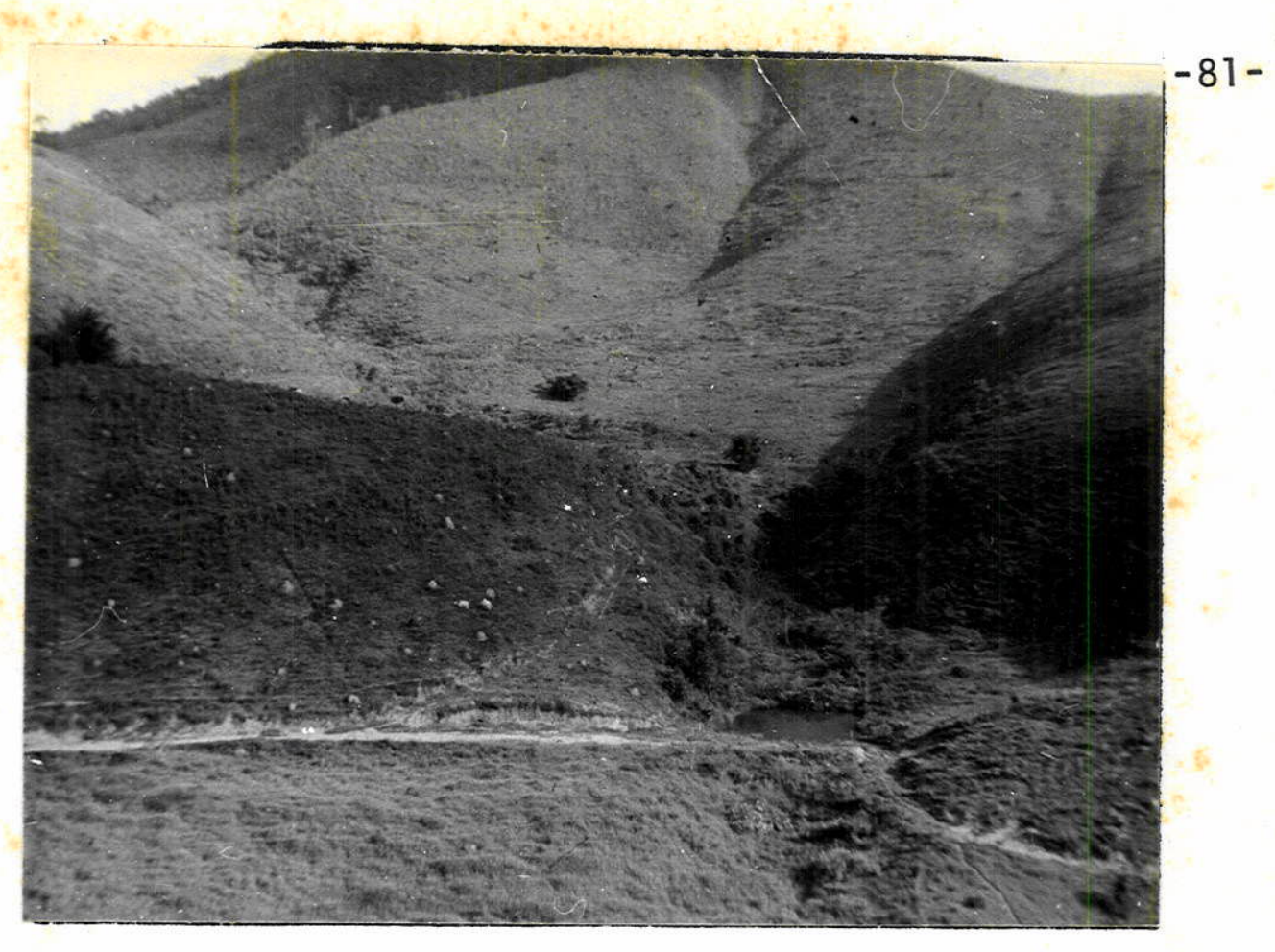

FOTO 33 - Patamar a meia encosta, sucedido de corredeiras no curso d'ägua a juzanteginstalada em migmati tos do Bloco Monteiro Lobato. Bairro do Juarez $(994514 / \mathrm{SJ}), 1,5 \mathrm{~km}$ a SE das margens do Rio do Peixe.

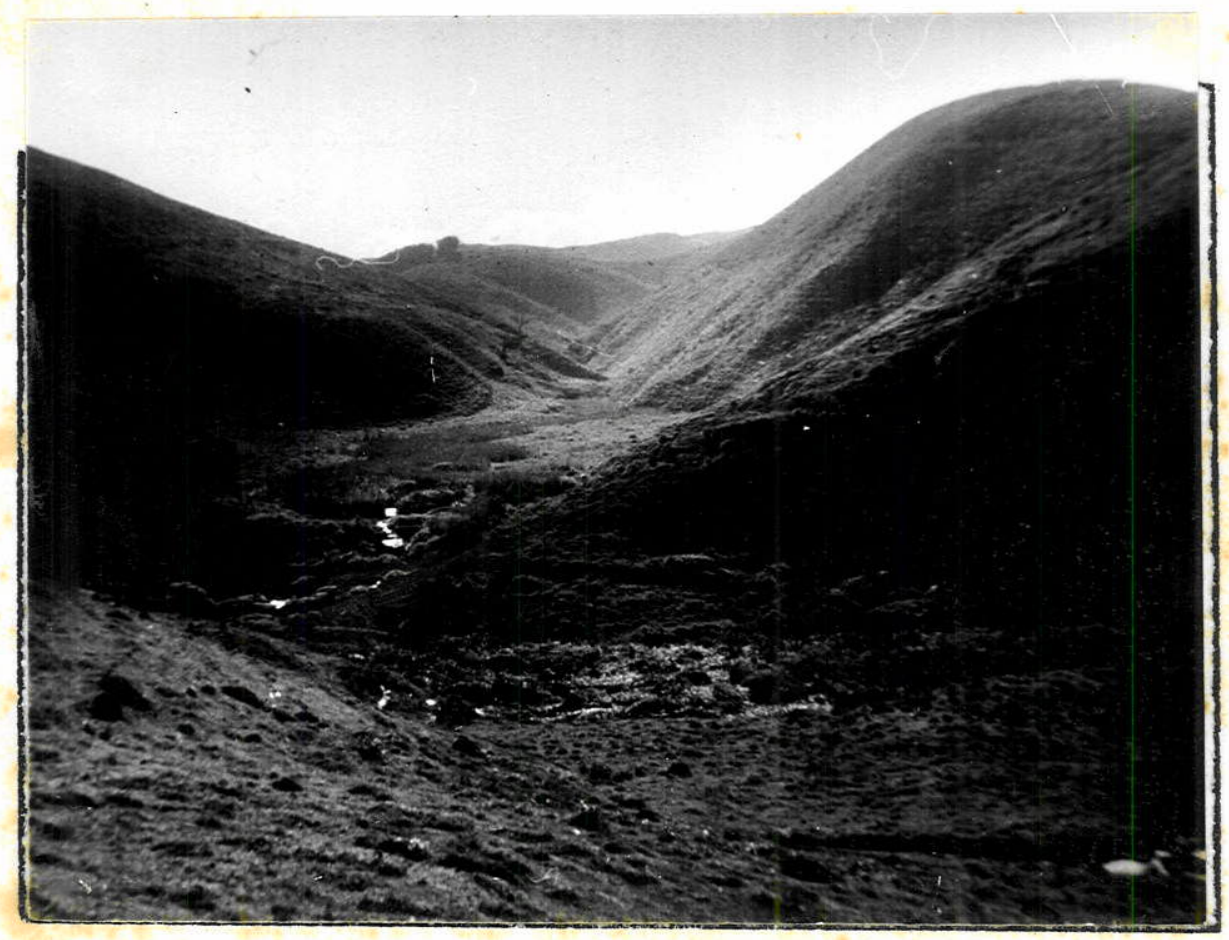

FOTO 34 - Patamar no relevo instalado sobre rochas cataclästicas da falha do Buquira. Depósitos aluvionares formam-se a montante das pequenas ca choeiras. Região da Fazenda Santa Luzia, estrá da Bairro do Caetë-Barragem do Rio Jaguari, $997395 /$ SJ. 
Não foram encontrados na literatura dados so bre ocorrēncias de minerais metālicos dentro dos limites dá folha estudada. A extração de minerais não metālicos consiste principalmente em portos de areia e pedreiras, embora existam numerosas olarias em atividade e algumas pequenas lavras de caulim abandonadas.

Os portos de areia (Foto 35), encontram- se espalhados em ambas as margens do Rio Paraíba aumentando de número nas proximidades de São José dos Campos. A areia do fundo do canal do rio é retirada por meio de dragas e separa da granulometricamente em silos ou peneiras inclinadas. 0 ma terial obtido é considerado de boa qualidade, pelo baixo teor em argilas. E utilizado na indústria de construção civil, inclusive em estruturas de concreto. Dados sobre produção e reservas atualizados não são disponīveis.

As pedreiras são de pequeno porte e em sua maioria encontram-se abandonadas. Nas pedreiras em atividade o material extraído é utilizado para calçamento, e as princi pais são a situada a norte do bairro do Morro Podre e na região do bairro Ponte do Costinha. Na primeira, ē explorada $\underline{u}$ ma rocha embrechītica, bastante foliada, de granulação média e porfiroblastos róseos de microclina. A facilidade com que a rocha se parte em placas favorece o seu uso como material de calçamento (vide Foto 30 ). A segunda pedreira, recentemen te instalada (1974), aproveita o quartzito de uma lente embu tida nos milonitos da Falha do Buquira. A rocha é bastante fraturada, com sistemas de juntas bem pronunciados, que fac $\underline{i}$ litam sua quebra em material de cascalho, usado como lastro para as estradas de terra da região. 


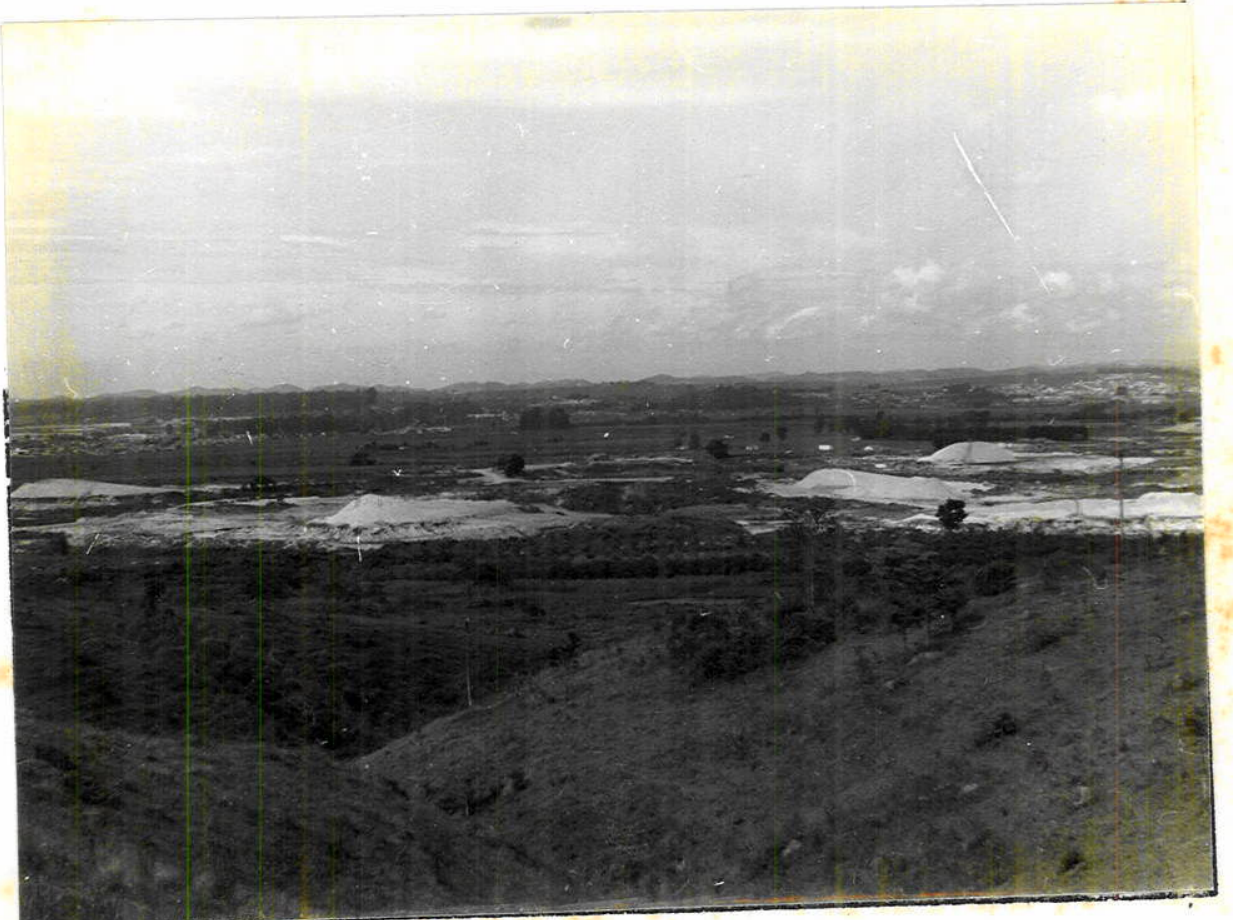

FOTO 35 - Portos de areia na värzea do Rio Paraíba. As cons truções urbanas à direita da foto (ao fundo) fazem parte da cidade de Jacarei. Pela estrada de acesso à barragem do rio Jaguari, a $3 \mathrm{~km} \mathrm{da} \mathrm{Via}$ Dutra. 
As maiores nedreiras abandonadas localizamse nas encostas da Serra do Palmital, onde se extraiu brita dos migmatitos homogêneos, na Fazenda São Sebastião e na região do bairro do Pedreguiho. Esta ūltima foi explora da pela fábrica da Providro em Caçapava.

A extração de caulim foi feita em a 1 guns pontos na quadricula, onde se retirou o material de bolsões de neossoma mais possantes. A pequena lavra abandonada situada no bairro Alto da Ponte é a maior delas.

Finalmente, cumpre lembrar a existência de numerosas olarias explorando os sedimentos de aluviões modernos para a fabricação de tijolos. Situam-se todas nas várzeas associadas aos Rios Buquira e Jaguari e alguns de seus tributários. A estimativa de uma produção global é di ficultada pelo grande nümero delas. 
A evolução geológica da ārea iniciou-se provavelmente com os episódios vinculados ao Ciclo Transamazónico, representados na quadrícula de modo ainda incerto, pe los granulitos do Bloco Bengala. A falta de datações radiométricas nestas rochas impede conclusões seguras a respeito.

Seguiram-se os fenômenos relacionados ao $\mathrm{Ci}$ clo Brasiliano e à Reativação Tectónica da Plataforma, que são aqui resumidos como segue:

1. Sedimentação geossinclinal: Os pacotes sedimentares que constituem os grupos São Roque e Açungui foram depositados provavelmente em sulcos geossinclinais distintos, con forme propuseram Hasui et al (1975), explicando que a si tuação atual é devida aos movimentos regmagênicos posteriores.

2. Magmatismo básico: A atividade magmática que se manifestou sofreu a ação do metamorfismo regional, de tal sorte que relaciona-se à fase de sedimentação geossinclinal, contemporaneamente ou logo após seus estāgios finais.

3. Metamorfismo regional: Ocorreu em fácies anfibolito nos blocos são José dos Campos e Bengala e em fácies xisto verde a anfibolito nos blocos Monteiro Lobato e Terra Boa. A sua ação foi contemporānea à primeira fase do dobramento principal, posto que a migmatização e o redobra mento afetaram metamorfitos já desenvolvidos. A xistosidade do tipo plano-axial é ainda observada localmente. 
4. Dobramento: Afetou as rochas da quadricula estudada em duas fases que se distinguem em termos de seus efeitos, mas que provavelmente não se separaram de muito no tempo. O dobramento da primeira fase teria gerado dobras isoclinais ou cerradas, recumbentes e intensamente transpostas, que estão representadas nos afloramentos pelas dobras intrafoliais portando xistosidade plano axial. A segunda fase é o dobramento principal, responsável pelas dobras da xistosidade e do bandamento dos migmatitos observadas nos afloramentos e pelas estruturas regionais culminantes e deprimidas. Tal feição de redobramento é comum em outras regiões, conforme assina laram Hobbs et al (1976).

5. Migmatização: Ocorreu durante ou logo após o metamorfís mo regional e a primeira fase de dobramento e transposi ção acima citada. Como os migmatitos estão frequentemen te dobrados, este episódio deu-se antes da segunda fase do dobramento. A existência de migmatitos mais evoluídos no núcleo das estruturas antiformais é devida à situação estrutural criada pela segunda fase de dobramento.

6. Magmatismo sintectónico: Rochas de natureza granitóide com caráter sintectónico se associam aos migmatitos mais evoluidos. Os dois corpos maiores têm contatos par cialmente discordantes, dando uma feição de granitos pa ra-autóctones.

7. Crenulação e transposição: A diminuição da intensidade dos fenómenos termo-tectónicos deu ensejo aos eventos de crenulação e transposição de estruturas, que afetaram as sequências ectiniticas e migmatiticas, criando localmente, dobras de cizalhamento. Estas dobras representam uma terceira geração na evolução dos dobramentos. 
8. Retrometamorfismo: Fenômenos de retrometamorfismo afetaram as rochas da área, particularmente as rochas granulí ticas do bloco Bengala. A cronologia relativa aos demais eventos não foi estabelecida.

9. Falhamentos transcorrentes e metamorfismo dinâmico: A ação dos movimentos regmagénicos parece ter se iniciado de modo precoce na evolução da faixa dobrada, interessan do ao intervalo de tempo que se estende do final do do bramento principal até os ūitimos movimentos havidos no Ciclo Brasiliano. As deformações deram-se de modo espasmōdico, afetando litologias diversas e produzindo rochas tipicas do metamorfismo dinâmico, submetidas a fenômenos de recristalização até mesmo posteriores ao movimento.

10. Sistemas de juntas: Os sistemas de juntas desenvolveramse no encerramento movimentos regmagēnicos e afetaram todas as rochas constituídas até então, de modo generali zado. Representam as ültimas estruturas formadas no Ciclo, sucedidas pela fase ortoplataformal.

11. Intrusões básicas: Apōs a consolidação da Plataforma Sul Americana, ao final do Ciclo Brasiliano, a Reativação Tectōnica que se iniciou no Mesozóico afetou a ārea, for mando pequenos corpos intrusivos concordantes de rochas básicas, nas cicatrizes deixadas pelos falhamentos trans correntes ou proximidades.

12. Falhamentos de gravidade e formação do Graben: Falhas de gravidade instalaram-se em tempos oligocénicos a pliocênicos, originando deslocamentos de blocos. Estas movimen tações criaram as feições que compõem o Sistema de Rifts da Serra do Mar (A1meida, 1976).

Na região estudada, parte da Bacia de Taubaté acha-se representada, condicionada por diversos falhamentos de gravidade que mostram evidéncias de uma evolução epi- 
-sódica, acompanhando a sedimentação terciāria e prosseguindo após seu término. Falhas transcorrentes foram reativadas e os últimos deslocamentos ocorridos são responsāveis por um basculamento de blocos e pelo aparecimento de deforma ções nos pacotes sedimentares.

13. Sedimentação recente: Os fenómenos mais recentes registrados na ārea são os relacionados ao aparecimento das formas de relevo atuais e à sedimentação aluvionar moderna, que ocupou os fundos de vales dos rios paraiba, Jaguari e Buquira, bem como de alguns de seus tributá rios. Fases nesta evolução têm sido reconhecidas, atravēs dos níveis de terraços deixados pela drenagem. 
A folha de São Josê dos Campos encerra litologias representativas de pelo menos dois importantes episó dios da evolução geológica da porção Sudeste da plataforma Sul-Americana: o Ciclo Brasiliano e a Reativação Wealdeniana. A existēncia de um núcleo pré-brasiliano foi admitida, o que depende de estudos futuros para comprovação.

Tendo em vista a exposição de resultados pre cedente, podemos resumir as principais conclusões:

1. As falhas transcorrentes que cortam a folha permitem uma abordagem em termos de blocos tectónicos que apresentam aspectos contrastantes entre si. São eles os blocos Terra Boa, Monteiro Lobato, Bengala, São José dos Campos e Serra do Jambeiro.

2. As rochas ectiniticas e migmatiticas presentes nos blocos exibem gradações entre si e vinculam-se ao Grupo Açungui, correspondendo às litologias englobadas pelo Complexo Ectinitico Pilar e pelo Complexo Migmatitico Em bu (Hasui e Sadowski, 1976), respectivamente.

3. As rochas granuliticas foram tentativamente correlaciona das ao Grupo Paraíba, e sua distribuição é restrita ao bloco Bengala. As rochas migmatiticas deste bloco mostram algumas caracteristicas de metamorfismo de alto grau.

4. As gradações entre os tipos litológicos, suas relações estruturais e os critérios de intensidade de migmatização evidenciam a existência de grandes estruturas sinfor 
mais e antiformais. Esta disposição é mais clara no bloco Monteiro Lobato.

5. Os corpos granitóides sintectōnicos alojam-se no interior de feições antiformais e são classificados como para-autōctones, no conceito de Read (1957), abrangendo uma diversidade de tipos petrográficos e exibindo associação intima com migmatitos evoluỉdos.

6. O metamorfismo regional deu-se em fācies xisto verde a anfibolito, à exceção do bloco Bengala, onde atingiu o fäcies granulito.

7. A evolução geológica regional è semelhante à descrita por Hasui e Sadowski (1976) para o Conjunto de Blocos Pa ranapiacaba, na região a oeste da cidade de São Paulo.

Do quadro evolutivo a que chegamos, ressaltam os seguintes fatos:

a) A segunda fase de deformação foi a principal e gerou as dobras do bandamento dos migmatitos, a maioria das dobras observadas nos afloramentos e as feições antiformais e sinformais reconhecidas. As dobras mesoscópicas apresentam geralmente espessamento de āpices e baixo ângulo inter-flancos, refletindo condições de Nivel Estrutural Inferior (Mattauer, 1973).

b) As falhas transcorrentes apresentam tipos litológicos que refletem, pelo grau de moagem e recristalização,a intensidade variāvel da milonitização no interior das faixas. Não são falhas de rejeito puramente direcional, posto que contēm ineações indicativas de uma significativa componente vertical.

c) As juntas relacionam-se aos eventos finais da evolução da faixa dobrada e parecem ter-se formado ao final dos movimentos regmagēnicos e após as movimenta- 
ções de massas granitōides.

8. As manifestações mesozóicas e terciārias associam-se ao efeito tracional da Reativação Wealdeniana da Plataforma, quando foram gerados falhamentos de gravidade e reativadas falhas antigas.

9. A Bacia de Taubaté é constituĩda pelos compartimentos Pa rateí e Jacareí; neste $\bar{u} 1$ timo, as espessuras encontradas são maiores.

10. Das duas formações sedimentares que constituem o Grupo Taubaté, apenas a formação Caçapava está exposta na região de São José dos Campos. Os sedimentos foram afeta dos por tectonismo, mesmo apōs a sedimentação.

11. A evolução da rede de drenagem atual e do relevo está fortemente condicionada pelas litologias e, particularmente na porção Pré-cambriana da folha, pelas estruturas presentes. 
0 mapa geolōgico da folha de São Josē dos Campos (SF-23-Y-D-II-1) foi elaborado em escala 1:50.000 e è apresentado neste trabalho, onde se descreve a geologia da folha e se reconstitui sua evo lução geológica, com particular interesse ao Pré-Cambriano.

A folha abrange āreas de sedimentos pertencentes à Bacia de Taubatē e de rochas de seu embasamento. Este ūltimo é caracteristicamente cortado por zonas de falhamento transcorrente que separam as litologias em blocos tectônicos distintos. As rochas regionais são filitos, xistos, quartzitos, migmatitos de tipos diversos e rochas granitóides, bem como granulitos expostos em um núcleo restrito. Pela inexistência de datações radiométricas, estes granulitos foram correlacionados tentativamente ao Grupo Paraíba, enquanto as demais rochas perten cem ao Grupo Açungui (Ciclo Brasiliano).

Algumas litologias exibem passagem gradual e estão dispostas em grandes feições antiformais e sinformais, reconhecidas a travēs de variação de intensidade de migmatização e de estruturas menores associadas. 0 dobramento regional, em escala mesoscópica, afetou a xistosidade das rochas e o bandamento dos migmatitos, criando dobras de āpices espessados. Os movimentos regmagênicos geraram rochas cataclásti cas de tipos variados, desde protomilonitos até milonitos, ultramilonitos e blastomilonitos. As litologias são indistintamente cortadas por sistemas de juntas que foram objeto de anālise visando determinar os padrões geométricos e suas relações para com as demais estruturas.

A reativação Meso-cenozōica da Plataforma conduziu ao aparecimento de "siızs" de diabāsio, de falhas de gravidade e reati vações de falhas antigas. Os sedimentos da Bacia de Taubatē depositaram se em depressão tafrogênica relacionada ao Sistema de Rifts da Serra do Mar, reconhecendo-se na folha de São José dos Campos dois compartimentos da mesma separados por falha. Os sedimentos foram afetados por tectonismo ainda apōs a sua formação. A geomorfologia atual estā intimamente relacionada às litologias e estruturas reconhecidas. Os recursos minerais em exploração consistem de materiais para construção, basicamente pedreiras e portos de areia. 
A diversas pessoas e Instituições queremos ex pressar a nossa mais profunda gratidão, por terem contribuĩdo para a realização do presente estudo.

O Professor Doutor Yociteru Hasui foi o dedicado orientador, efetiva e sistematicamente, de todas as eta pas do trabalho.

0 CNPq - Conselho Nacional de Desenvolvimento Científico e Tecnolögico concedeu-nos Auxỉlio de Pesquisa pa ra as atividades de campo e Bolsa de Pesquisa para a fase f $\underline{\underline{j}}$ nal de elaboração.

O Professor Doutor Josē Moacyr Vianna Coutinho, o Professor Doutor Vicente A.V.Girardi e o Professor Doutor Jacques Delhal nos auxiliaram em estudos ao microscópio petrogräfico.

O Professor Doutor Georg R.Sadowski, durante a elaboração do trabalho e a preparação do texto final, manteve conosco proveitosas discussões.

Ao Professor Doutor Evaristo Ribeiro Filho de vemos o cuidadoso preparo das fotomicrografias.

0 então aluno do 30 ano do Curso de Geologia do IG, Sr. Geraldo Luiz Nunes Gusso e o colega geölogo Ginal do A.Cruz Campanha acompanharam-nos durante os trabalhos de campo.

0 IPT - Instituto de Pesquisas Tecnológicas, do Estado de São Paulo S.A., atravēs do chefe do Agrupamento de Geologia Geral, Geólogo Waldir Lopes Ponçano, deu-nos 
inestimāvel apoio. A desenhista, Srta. Mirna Mongini Ferra cini e aos técnicos Sr.otāvio Martins e Waldomiro de 01 iveira, devemos a qualidade artīstica do Mapa Geológico fi-
nal.

A Administração do Instituto de Geociências da Universidade de São Paulo ofereceu o suporte material e os meios para a realização da presente pesquisa. Ao pessoal técnico-administrativo do IG devemos grande contribui ção, particularmente às seguintes pessoas: Sra. Melany. T. Isauk e Claudio Hopp, pela confecção das seções delgadas; Sr. Pedro Gennari Filho, pelo desenho dos grāficos e ilustrações; Sra. Claudete Salinas Franzosi, pela cuidadosa da tilografia dos originais; Sr. Jaime de Souza Marcos, pela confecção das fotografias; Sr. Jaime Alves Silva e à equipe do Setor Grāfico, pela impressão e montagem final do
texto. 


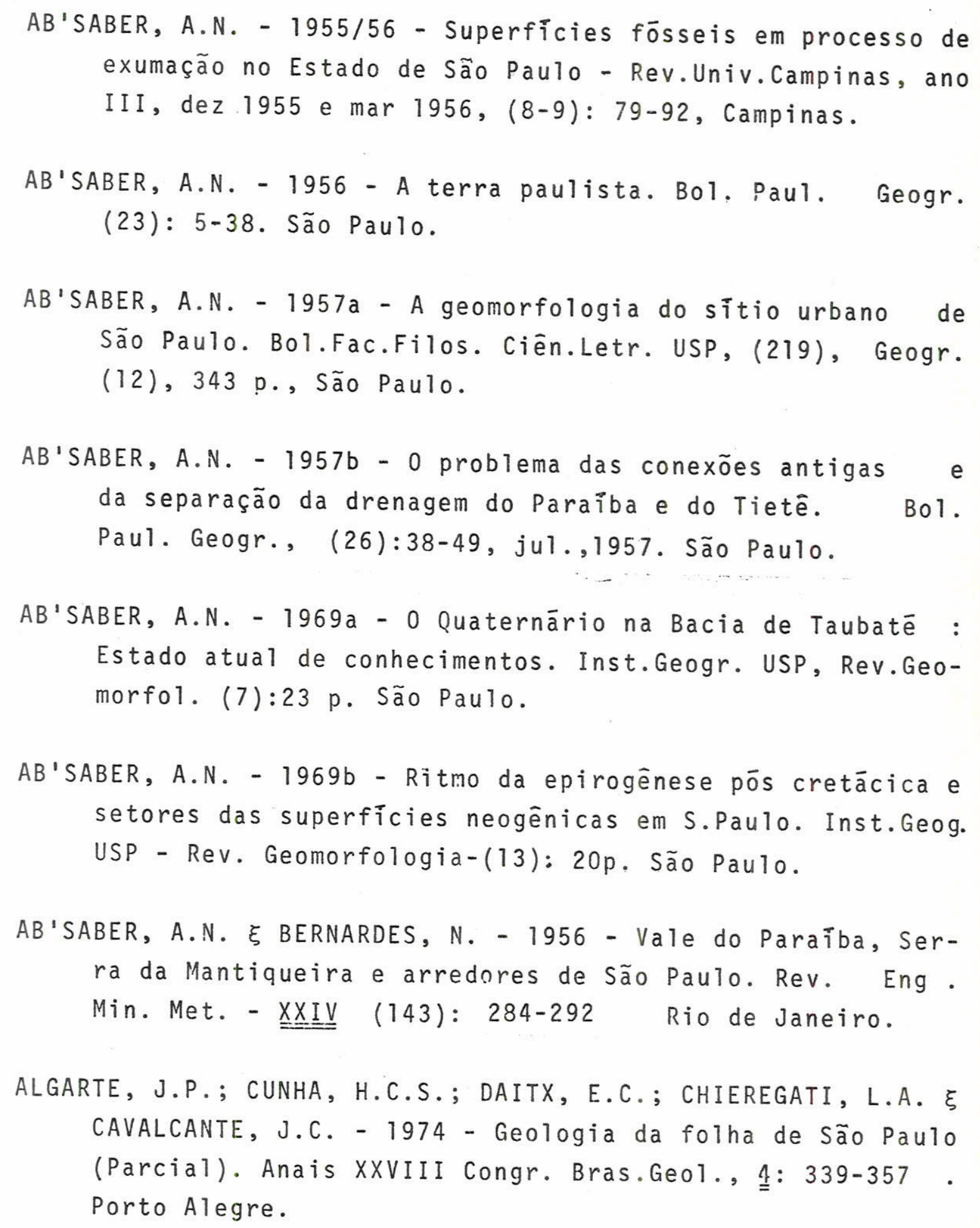


ALMEIDA, F.F.M.de - 1955 - As camadas de São Paulo e a Tectónica da Serra da Cantareira. Soc. Bras.Geol., Bol. (2): $23-40$.

ALMEIDA, F.F.M.de - 1957 - Vale do Paraíba - in Relat.anual do Diretor, DGM-DNPM, pp.90-91, 1958 - Rio de Janeiro.

ALMEIDA, F.F.M. de - 1964 - Fundamentos Geológicos do Re levo Paulista. in Geologia do Estado de S.Paulo. ReleIGG. (41): 167-263. São Pau1o.

ALMEIDA, F.F.M. de - 1967 - Origem e evolução da plataforma Brasileira. Div. Geol. Miner. DNPM, Bol. (241): $36 \mathrm{p}$. Rio de Janeiro.

ALMEIDA, F.F.M. de - 1969 - Diferenciação Tectônica da Plataforma Brasileira. XXIII Congr. Bras. Geol., Anais, ll:
29-46. Salvador.

ALMEIDA, F.F.M.de - 1976 - The system of continental rifts bordering the Santos Basin. Intern. Symp. on Contin. Margins of Atlantic Type. An.Acad. Bras. Cienc., 48 (supl): 15-26, Rio de Janeiro.

ALMEIDA, F.F.M. de ; AMARAL, G.; CORDANI, U.G. $\xi$ KAWASHITA, K. - 1973 - The Precambrian evolution of the South Ame rican Cratonic Margin South of the Amazon River. In the Ocean Basins and Margins (ed.Nairn, A.E. -Stehli, F.G.); Plenum Publ.Co., l : 411-446 - New York - pg.96.

ALMEIDA, F.F.M. de; HASUI, Y. $\xi$ BRITO NEVES, B.B. de - 1976 The Upper Precambrian of South America. Bol. IG., Inst. Geoc. USP, 7: 45-80, São Paulo.

ALVES, F.R. - 1975 - Contribuição à geologia da Região de Salesōpolis - Guararema, S.Paulo. Inst. Geoc. USP - Te se (inédita), 136p. 
AMARAL, G.; CORDANI, U.G.; KAWASHITA, K. $\xi$ REYNOLDS, J.H.1966 - Potassium-argon dates of basaltic rocks from Southern Brazil. Geoch. et Cosm. Acta, 30 (2):159-189 oxford.

BEURLEN, K. - 1950 - Alguns restos de crustāceos decāpodes de āgua doce fōsseis no Brasil. An. Acad. Bras. Ciên., XXI (4): 453-456, Rio de Janeiro.

BILLINGS, M.P. - 1954 - Structural Geology - 2a. ed., Pren tice Hall Inc., 514 p., New York.

BJORNBERG, A.J.S.; GANDOLFI, N. G PARAGUASSU, A.B. - 1965Novas observações sobre a tectōnica moderna do leste de São Pau1o. Rev. Eng. Min. Met. - XLI (244):137-140 Abri1-1965, Rio de Janeiro.

BRANNER, J.C. - 1918 - Geologic Map of Brazil. Bull. Geol. Soc. Amer., 29. Versão portuguesa pelo Autor, 1918 (B.S.G).

CARNEIRO, C.D.R. - 1974 - o precambriano na região do Vale do Paraỉba. Semin., Curso de Pōs-Graduação, Inst.Geoc. USP, $21 p$. (inēdito).

CARNEIRO, C.D.R.; HASUI, Y. $\xi$ GIANCURSI, F.D. - 1976 - EStrutura da Bacia de Taubaté na região de São José dos Campos. XXIX Congr. Bras. Geol., Res. Trab., pp. 221223. Belo Horizonte. Idem, Anais (no prelo).

CASTER, K. $\xi$ MENDES, J.C. - 1952 - in Du Toit, A.L. (1952) Comparação geológica entre a Amērica do Sul e a Āfrica do Sul. Div. Geol. Miner., DNPM, 179 p., Rio de Ja neiro. 
CAVAlCANTE, J.C. $\xi$ KAEFER, L-Q. - 1974 - Geologia da folha de Santos (parcial). Anais XXVIII Congr. Bras. Geol., 4: 227-245, Porto Alegre.

COLTRINARI, L. - 1975 - Contribuição à geomorfologia da re gião de Guaratinguetá-Aparecida. Sērie teses e Monog. Inst.Geogr., USP. (17): 156p. São Paulo.

CORDANI, U.G.; DELHAL, J. $\xi$ LEDENT, D. - 1973 - Orogenēses Superposēes dans le Précambrien du Brésil Sud-Oriental (Etats de Rio de Janeiro et de Minas Gerais). Rev. Bras. Geoc., $\underline{\underline{3}}(1): 1-22$, São Paulo.

CORDANI, U.G.; COIMBRA, A.M.; BOTTURA, J.A. $\xi$ RODRIGUES, E.D.M. - 1974 - Geologia da região de Cruzeiro e Cachoeira Paulista e sua importância na interpretação da evolução tectōnica do Vale do Paraíba. Rev. Geol i Cien. Tecn., CEPEGE, (6): 9-30. São Paulo.

Coutinho, J.M.V. - 1972 - Petrologia do Pré-Cambriano em São Paulo e arredores. Bol.IG., Inst.Geoc.USP. 3: 5-99, São Paulo.

DELHAL, J.; LEDENT, D. $\xi$ CORDANI, U.G. - 1969 - Ages Pb/U, $\mathrm{Sr} / \mathrm{Rb}$ et $\mathrm{Ar} / \mathrm{K}$ de formations métamorphiques et graniti ques du sud-est du Brésil (Etats de Rio de Janeiro et de Minas Gerais). Ann.Soc.Geol. Belgique, 吕: 271-283.

DERBY, O.A. - 1895 - A denominação Serra da Mantiqueira, Rev. Inst. Hist. e Geogr. S.Paulo, (1):3-15, São Pau10 .

EBERT, H. - 1957 - Beitrag zur Giiederung des Prákambriums in Minas Gerais - Geo1. Rundschau, 45 (3): 471-521.

EBERT, H. - 1967 - A estrutura Pré-Cambriana do Sudeste de Minas Gerais e äreas adjacentes-Bol.Paran.Geoc.(26): 42-45 - Curitiba. 
EBERT, H. - 1968 - Ocorrências da fácies granulítica no Sul de Minas Gerais e em āreas adjacentes, em dependência da Estrutura Orogēnica: Hipōteses sobre sua Origem.An. Acad. Bras. Ciênc., $\underline{\underline{40}}$ (supl.): 215-229, Rio de Janeiro.

FLORENCE, G. ॄ PACHECO, J. - 1907 - Notas geológicas sobre o Rio Tietē - Exploração do Rio Tietê. Com. Geogr.Geol. S.Paulo, Fölio p. 9-15, São Paulo.

FLORENCE, G. छ PACHECO, J. - 1929 - Carta geológica do Estą do de São Paulo. Com. Geogr. e Geol. (SP), 1:2.000.000 São Paulo.

FRANCO, R.R. छ VANDOROS, P. - 1966 - Determinações de idades de granitos da Região de Mogi das Cruzes, São Pau10, pelos métodos Potāssio/Argōnio e Rubỉdio/Estrôncio An. Acad. Bras. Ciēn., $\underline{\underline{38}}$ (2): 289-292, Rio de Janeiro.

FRANGIPANI, A. - 1963 - Idēías sobre a gēnese do Vale do Pạ raỉba. O IGG., Rev., São Pau10, 16: 31-39.

FRANGIPANI, A. छ PANNUTI, E.L. - 1965 - Estudos hidrogeológicos na Bacia de Taubatē, entre Jacareī e Quiririm. Bol. Inst. Geogr. Geol., (42): 126p., São Paulo.

FREITAS, R.0. de - 1951 - Relevos policíclicos na Tectônica do Escudo Brasileiro. Bol. Paul. Geogr. (7): 3-19, São Paulo.

FREITAS, R.0. de - 1956 - Considerações sobre a Tectōnica e a Geologia do Vale do Paraíba. Rev. Eng. Min. Met.XXIV (143): 276-283. Rio de Janeiro.

FREITAS, R.0. de - 1957 - Tectônica e Geologia do Vale do Paraíba. Esc. Eng. S.Carlos, Pub1.11, (Geol.4): 40p. 
$-100-$

FREITAS, R.0. de - 1976 - Definição Estrutural, Petrológica e Geotectonica das Cintas Orogênicas antigas do Litoral Norte do Estado de São Paulo. Bol., Inst. Geol.Est. S.Paulo, (1): 1-176, São Paulo.

hASUI, Y.; PENALVA, F. $\xi$ HENNIES, W.T. - 1969 - Geologia do Grupo São Roque. Anais XXIII Congr. Bras. Geol.,p.101134, Salvador.

HASUI, Y. - 1973 - Tectōnica da ārea das folhas de São Proque e Pilar do Sul. Tese Livre Doc., Inst. Geoc. USP(inédita), 190p., São Paulo.

HASUI, Y. - 1975a - Evolução Polifásica do Precambriano a oeste de São Paulo. Bol.IG., Inst. Geoc.USP - $\underline{\underline{6}}: 95-108$

HASUI, Y. - 1975b - Geologia da Folha de São Roque. Bol.IG. Inst. Geoc. USP, 6 : 157-183, São Paulo.

HASUI, Y. छ HAMA, M. - 1972 - Geocronologia do Grupo São Roque pelo método do Potássio-Argōnio. Rev. Bras.Geoc. $\stackrel{2}{\cong}(1): 18-24$, São Paulo.

HASUI, Y.; CARNEIRO, C.D.R. $\xi$ COIMBRA, A.M. - 1975 - The Ribeira Folded Belt. Rev. Bras. Geoc.; $\underline{\underline{5}}(4)$ : 257-266. São Paulo.

HASUI, Y.; CARNEIRO, C.D.R.; GIANCURSI, F.D. छ GUSSO, G.L.N. 1976 - Condicionamento tectónico da Bacia de São Paulo. XXIX Congr. Bras. Geol., Res.Trab., pp. 224-225, Belo Horizonte. Idem, Anais (no pre10).

HASUI, Y. छ SADOWSKI, G.R. - 1976 - Evolução Geolögica do Pré-Cambriano na região sudeste do Estado de São Paulo. Rev. Bras. Geoc., 6 (3): 182-200 -São Paulo. 
HASUI, Y.; SADOWSKI, G.R.; CARNEIRO, C.D.R. G FUCK, G.F. inédito - Geologia das Folhas de Itapecerica da Serra e Embu-Guaçū (em preparação).

HIGGINS, M.W. - 1969 - Cataclastic Rocks. U.S. Geol. Survey Prof. paper (687): 97p., Washington.

HOBBS, B.E.; MENS, W.D. $\xi$ WILLIAMS, P.F. - 1976 - An outline of structural geology. ed. John Wiley.

JUNG, J. $\xi$ ROQUES, M. - 1952 - Introduction à l'étude zóneo graphique des formations cristallophyliēnes. Bull. Serv. Carte Geo1. France, (235): 1-62.

KNECHT, T. - 1964 - Pré-Cambriano Inferior. in Geologia do Estado de São Paulo. Bol. Inst. Geogr. Geol. S.Paulo, (41): 14-36, São Paulo.

LAMEgO, A.R. - 1949 - Anālise Tectōnica e morfológica do Sistema da Mantiqueira. in II Congr. Pan-Amer. Eng. de Minas e Geol., 1946, Petrópolis; III (2a. comissão) : 247-326, Rio de Janeiro, 1949.

MARMO, V. - 1971 - Granite petrology and the granite problem. Elsevier, 244p. Amsterdam.

MATTAUER, M. - 1973 - Les dēformations des matēriaux de 1' écorce terrestre. Hermann ed., 493 p., Paris.

MAULL, 0. - 1930 - Vom Itatiaia zum Paraguay - Karl. W. Hie semann, 366 p., Leipzig.

MEDEIROS, A.M.S. छ AB'SABER, A.N. - 1969 - Introdução à Geomorfologia da ārea de São José dos Campos (S.P.) Cad. Cien. da Terra, Inst. Geogr. USP, (12): 1-5, São Paulo. 
MEHNERT, K.R. - 1968 - Migmatites and the Origin of Granitic Rocks. Elsevier, 393 p., Amsterdan.

MELFI, A.J. - 1967 - Idades de basaltos da Bacia do Paraná in Freitas, R.0. (1976) - Definição petrológica, Estrutural e Geotectônica das Cintas Orogênicas antigas do Litoral Norte do Estado de São Paulo. Bol. Inst. Geol. Est. S.Pau10, (1): 1-176, São Paulo.

MELFI, A.J.; CORDANI, U.G.; CARVALHO, A.; MINIOLI, B.; PENALVA, F.; BASEI, M.A.S. छ COUTINHO, J.M.V. - 1976 Projeto Paräiba, Geologia das folhas de Lorena e Cruzeiro. Relat. Conv. DNPM/IGUSP, 74p. (inédito).

MENDES, J.C. $\xi$ PETRI, S. - 1971 - Geologia do Brasil. Inst. Nac. Livro, Bibliot. Univ. Rio de Janeiro, Geociēncias, $\underline{\underline{9}}$ : $207 p$.

MEZZALIRA, S. - 1962 - Novas ocorrēncias de vegetais fós seis cenozóicos no Estado de São Paulo. Revista O IGG XV (nọ ūnico): 73-89- São Pauto.

MINIOLI, B. - 1971 - Determinações Potássio - Argōnio em rochas localizadas no Litoral Norte do Estado de São Pau10. Acad. Bras. Ci., Anais, 43 (2): 443-448, Rio de Janeiro.

MORAES REGO, L.F.de-1933a - Contribuição ao estudo das for mações predevonianas de São Paulo. Publ. Inst. Astron. Geogr. São Pauto, 43p.

MORAES REGO, L.F.de-1933b - As formações cenozōicas de São Paulo. Anuārio ESC. Politēcnica SP., II: 231-267. São Paulo.

PAOLIELLO, P.C. - 1964 - Pré-Cambriano Superior. in Geologia do Estado de São Paulo. Bol. Inst. Geog. Geol. S. Pau10, (41): 37-44, São Pauto. 
PAULA COUTO, C.de - 1956 - Une chauve-souris fossile des a gilles feuilletēes plēistocènes de Tremembē, ētat de São Paulo, Brésil. Actes IV Congrĕs Intern. Quatern. Rome-Pisa, 1953, 1: 343-347, Roma.

PAULA COUTO, C.de - 1958 - Idade Geolögica das bacias cenozóicas do Vale do Paraỉba e de Itaboraí. Bol. Museu Nac., N.S., Geol. (25): 17p.

PAULA COUTO, C.de $\xi$ MEZzALIRA, S. - 1971 - Nova conceitua ção geocronolōgica de Tremembē, Estado de São Paulo, Brasil. An. Acad. Bras. Cienc. 43 (supl.): 473-488,Rio de Janeiro.

PISSIS, A. - 1842 - Memoire sur la position geologique des terraires de la parte australe du Brasil, et sur les soulevements qui a divers epoques, on change de relief de cette contres. Acad. Sci. Paris, Comptes Rendus.141044-1046, Memoirs Acad.Sci. Paris 10: 353-413, 1848Paris.

RAMSAY, J.G. - 1967 - Folding and fracturing of rocks. MC Graw-Hill Book Co., 568 p. New York.

READ, H.H. - 1957 - The granite controversy. Thomas Murby Co., 430 p., London.

RIBEIRO Fọ., R. - 1948 - Caracteres físicos e geológicos da Bacia do Paraiba. DNPM/DGM, Rio de Janeiro, Bol.,(127) $55 p$.

RICCI, M. छ PETRI, S. - 1965 - Princīpios de aerofotogrametria e interpretação geológica. Ed. Nacional, 226 p., São Paulo.

RIDEG, P. - 1974 - Geology and structure of a portion of the Serra do Mar in Eastern São Paulo, Brazil. Ph. D: Thesis, State University of New York at Binghamton (inēdito). $145 p$. 
$-104-$

ROQUES, M. $\xi$ POLKANOV, A.A. - 1968 - Nomenclature of migma tites, in Mehnert, K.R. (1968) Migmatites and the 0rigin of Granitic Rocks. Elsevier, 405p., Amsterdam.

ROSIER, G.F. - 1965 - Pesquisas geológicas na parte oriental do Estado do Rio de Janeiro e na parte vizinha do Estado de Minas Gerais. DNPM/DGM, Bol. (222): 43p.Rio de Janeiro.

RUHLAND, M. - 1973 - Méthode d'étude de la fracturation na turelle des roches associēe a divers mödeles structuraux. Sci. Geo1., Bu11., 26 $(2-3): 91-113$, Strasbourg.

SADOWSKI, G.R. - 1974 - Tectōnica da Serra de Cubatão,S.P. Tese de Doutoramento, Inst. Geoc. USP (inëdita),159p.

SADOWSKI, G.R. $\xi$ CARNEIRO, C.D.R. - 1974 - 0 charnoquito de São Francisco Xavier, SP. Anais XXVIII Congr.Bras. Geo1., 4: 207-211, Porto Alegre.

SANTOS, R. da S. - 1950 - Vestīgio de ave fóssil nos folhe Thos betuminosos de Tremembē, An. Acad. Bras. Cien., $\underline{\underline{22}}$ (4): 445-446, Rio de Janeiro.

SANTOS, R. da S. - 1970 - Nova evidência paleontológica da idade pleistocênica dos estratos da Bacia do Paraíba. Eng. Miner. Metal., 51 (301): 10p. Rio de Janeiro.

SANTOS, R.da S. छ TRAVASSOS, H. - 1955 - Caracídeos fósseis da Bacia do Paraiba. An. Acad. Bras. Cien., XXVII (3): 297-321., Rio de Janeiro.

SEDERHOLM, J.J. - 1907 - in Sederholm, J.J. (1967); Selected works - Granites and Migmatites, ed. 01 iver and Boyd, Ltd., 608 p., Edinburgh: 
Suguio, K. - 1969 - Contribuição à Geologia da Bacia de Tau batē. Bol. Esp. F.F.C.L.-USP, 106p., São Paulo.

TITARELLI, A.H.V. - 1975 - 0 Vale do Parateỉ: estudo geomor folögico. Série teses e Monogr., Inst. Geogr. USP, (13): 186 p., São Paulo.

TRICART, J. $\xi$ SILVA, T.C.da - 1958 - Aspectos gerais da sedimentação da Bacia de Taubaté, São Paulo, Brasil. Not. Geomorf., 1 (1):6-13. Campinas.

TURNER, F.J. $\xi$ VERHOOGEN, J. - 1960 - Igneous and metamor phic petrology. 2a. ed., McGraw Hill Book Co., 64p. New York.

TURNER, F.J. $\xi$ WEISS, L.E. - 1963 - Structural analysis of metamorphic tectonites. McGraw Hill Book Co., 545p.

VANDOROS, P. - 1966 - Idades de basaltos da Bacia do Paranā in Freitas, R.0. (1976) - Definição petrológica, Estru tural e Geotectōnica das Cintas Orogēnicas antigas do Litoral Norte do Estado de São Paulo. Bol. Inst. Geol. Est. S.Paulo, (1): 1-176, São Paulo.

VANDOROS, P. $\xi$ OLIVEIRA, M.A.F. - 1969 - Geologia e petrografia da região de Taiaçupeba e arredores, SP. An. Acad. Bras. Cien., 41 (2): 181-194, Rio de Janeiro.

VERDADE, F.da C. et al - 1961 - Solos da Bacia de Taubatē, (Vale do Paraỉba): Levantamento e reconhecimento, sé ries monotipicas, suas propriedades genético-morfológi cas, físicas e quỉmicas. Bragantia, 20 (4): 43-322, Cam pinas.

VERDADE, F.da C. G HUNGRIA, L.S. - 1966 - Estudo genētico da Bacia Orgânica do Vale do Paraíba. Bragantia, 25 (16): 189-202, Campinas. 
VIALON, P.; RUHLAND, M. $\xi$ GROLIER, J. - 1976 - Elements de Tectonique Analytique. 1a. ed., Ed. Masson, 118p., Pa ris.

WASHBURNE, C. - 1930 - Petroleum Geology of the São Paulo State, Brazil - Comm. Geogr. Geol. do Est. S.Paulo, bol. (22): 282p., São Paulo.

WEGMANN, E. - 1935 - Zur Deutung der Migmatite - Geol. Run dschau, (XXVI): 305-350.

WERNICK, E.; OLIVEIRA, M.A.F.; KAWASHITA, K.; CORDANI,U.G. छ DELHAL, J.0. - 1976 - Estudo geocronológico pelo mé todo $\mathrm{Rb} / \mathrm{Sr}$ em rochas do Bloco Jundiai e regiões adjacentes. Rev. Bras. Geoc., 6 (2): 125-135, São Paulo.

WHITTEN, E.H.T. - 1966 - Structural Geology of folded Rocks. Rand McNally and Co., 663p. 
SF- 23-Y-D-D-I-1
SAO JOSÉ DOS CAMPOS

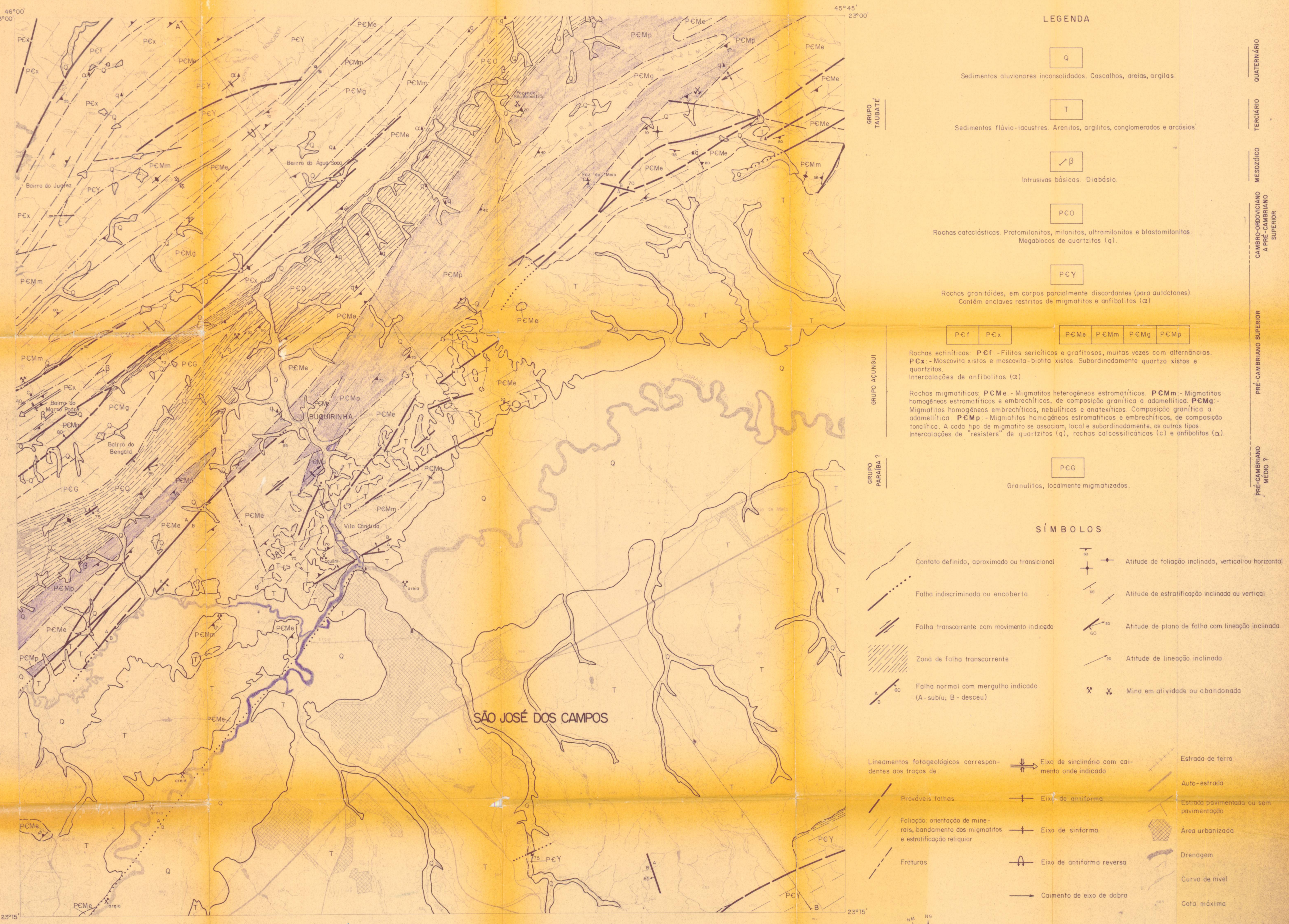

BASE TOP DOGAAFICA: MAPA GEOLÓGICO 


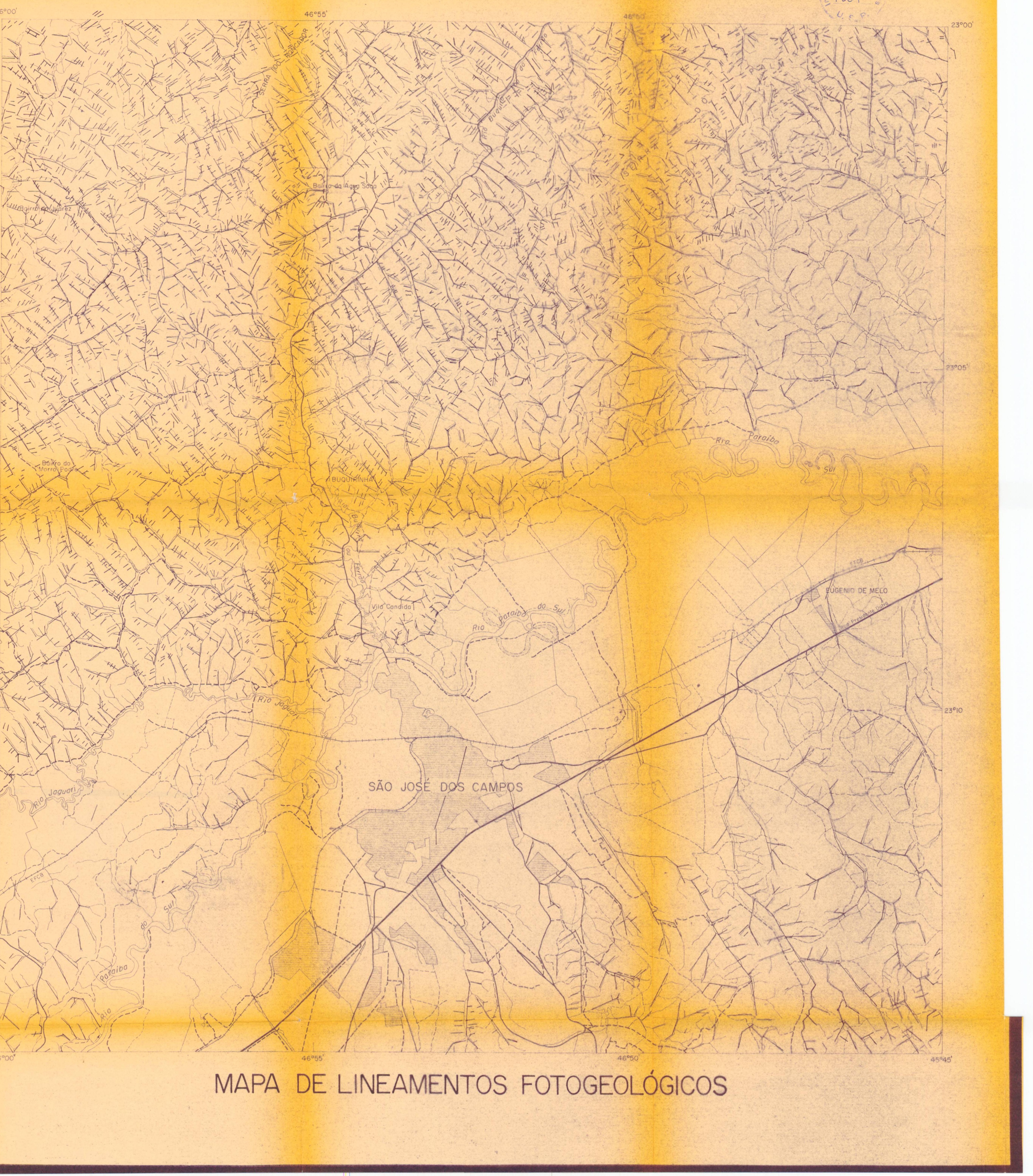

